\title{
ARABIA SAUDI: UN COLOSO CON LOS PIES DE BARRO
}

\author{
Eugenia López-Jacoiste Díaz ${ }^{1}$ \\ Universidad de Navarra
}

\begin{abstract}
Resumen:
El fundamento político-religioso del Reino de Arabia Saudí es el wahabismo que marca su identidad, su sociedad y su política. La dinastía Al Saud defiende y expande el islam sunní en la región y fuera de sus fronteras. Para poder entender los intereses y objetivos de la política exterior saudí, este artículo analiza los principales elementos geopolíticos al servicio de la estabilidad y hegemonía de la casa Al Saud en la región más convulsa de Oriente Medio. El Gobierno saudí está desarrollando una política exterior, insospechada en el pasado para mantener su histórica alianza con Washington, a pesar de los altibajos, y transformar las viejas rivalidades entre Riad y Teherán en nuevas oportunidades, incluso con Israel. Este cambio en la política exterior saudí se debe al controvertido Príncipe Heredero Mohamed bin Salmán que sabe aprovechar la cambiante geopolítica regional y los instrumentos financieros saudíes, pero también los militares y tecnológicos a favor de una Arabia Saudí más proactiva y moderna, a pesar de sus debilidades.
\end{abstract}

Palabras Clave: Arabia Saudí, wahabismo, geopolítica del crudo, Irán, Estados Unidos, Siria, Yemen, Israel, Golfo Pérsico

Title in English: Saudi Arabia: a colossus with clay feets

\section{Abstract:}

The political-religious foundation of the Kingdom of Saudi Arabia is Wahhabism that marks its identity, society and politics. The Al Saud dynasty defends and expands Sunni Islam in the region and beyond its borders. In order to understand the interests and objectives of Saudi foreign policy, this article analyzes the main geopolitical elements at the service of the stability and hegemony of the Al Saud house in the most turbulent region of the Middle East. The Saudi government is developing a foreign policy, unsuspected in the past, to maintain its historic alliance with Washington, despite the ups and downs, and to transform the old rivalries between Riyadh and Tehran into new opportunities, including with Israel. This change in Saudi foreign policy is due to the controversial Crown Prince Mohamed bin Salman who knows how to take advantage of the changing regional geopolitics and Saudi financial instruments, but also the military and technological in favor of a more proactive and modern Saudi Arabia, despite his weaknesses.

Key words: Saudi Arabia, Wahhabism, Oil Geopolitics, Iran, United States, Syria, Yemen, Israel, Persian Gulf

Copyright @ UNISCI, 2021.

Las opiniones expresadas en estos artículos son propias de sus autores, y no reflejan necesariamente la opinión de UNISCI. The views expressed in these articles are those of the authors, and do not necessarily reflect the views of UNISCI

\footnotetext{
${ }^{1}$ Eugenia López-Jacoiste Díaz es Profesora Titular de Derecho Internacional Público y Relaciones Internacionales en la Universidad de Navarra.

E-mail: <ejacoiste@unav.es>

DOI: http://dx.doi.org/10.31439/UNISCI-123
} 


\section{Introducción}

Desde que Ibn Saud proclamó en 1932 el Reino de Arabia Saudí hasta nuestros días, Arabia Saudí ha llegado a ser un actor relevante en el ámbito musulmán de Oriente Medio gracias a la suma de una serie de factores geopolíticos, económicos y religiosos. Su historia muestra un asombroso acuerdo entre lo antiguo y lo nuevo y entre el poder del monarca y el islam sunní (wahabismo), donde las dos mezquitas santas de La Meca y Medina marcan la idiosincrasia saudí, su sociedad, la política nacional y geopolítica internacional y regional.

Geográficamente, Arabia Saudí ocupa una posición estratégica de suma importancia para el equilibrio regional al estar situada en el centro de la Península Arábiga, entre el mar Rojo y el Golfo Pérsico, al sur del Creciente Fértil de la Antigüedad. Sus vencimos más próximos son Jordania, Irak y Kuwait en su frontera norte; Yemen por el sur, Omán al sureste y al este los Emiratos Árabes Unidos, Catar y Bahréin. Cuenta con una superficie total de 2.150.000 $\mathrm{Km}^{2}$, que equivalen a cuatro veces el tamaño de España. Según el último censo registrado en el Banco Mundial (2019), cuenta con una población de 34,27 millones, de los cuales un $85 \%$ son musulmanes sunníes, $14 \%$ chiíes, y un $1 \%$ de cristianos. Pero existe una importante brecha generacional: cerca del $50 \%$ de esta población es menor de 30 años y esto contrasta con la senectud habitual de sus dirigentes políticos.

La principal fuente de riqueza del reino saudí es el crudo, lo que le permite ser el mayor productor mundial de petróleo $(8,54 \mathrm{mb} / \mathrm{d})$ y el mayor exportador $(7 \mathrm{mb} / \mathrm{d})$ ya que alberga las segundas mayores reservas probadas de crudo del planeta (264.200 millones de barriles) tras Venezuela. Es uno de los cinco Estados fundadores de la Organización de Países Exportadores de Petróleo (OPEP), junto con Irán, Irak, Kuwait y Venezuela. En 2020 registró un superávit en su balanza comercial de un 5,82\% de su PIB, algo inferior al alcanzado en 2019, que llegó el 13,68\% del PIB. Esta variación se debe al descenso de las exportaciones - como consecuencia de la crisis por la pandemia covid-19- y a la disminución de la demanda interna que también ha provocado una disminución de las importaciones. Sus exportaciones de 2020 cayeron un $35 \%$ respecto al año anterior lo que representa un 24,78\% de su PIB. En 2021, la producción y las exportaciones de petróleo han aumentado gradualmente y de forma significativa. La decisión de la OPEP+ en 2020 de recortar las cuotas de producción de petróleo es probable que se vaya reconsiderando gradualmente lo que permitirá que la producción de petróleo de Arabia Saudita aumente después de haberse producido una reducción importante en los dos últimos años ${ }^{2}$.

Sus principales proveedores son China, Japón y la India, si bien mantiene relaciones comerciales fluidas con la Unión Europa en el contexto del Acuerdo de Cooperación de 1988 firmado entre la Unión Europa y el Consejo de Cooperación de los Estado Árabes del Golfo, comúnmente conocido como Consejo de Cooperación del Golfo (CCG) del que forman parte Arabia Saudita, Bahréin, Emiratos Árabes Unidos, Kuwait, Omán y Catar. A pesar de que la economía saudí está estancada, su PIB per cápita en 2020 fue de $17.985 €$, por lo que se encuentra ente el puesto 44 de los 196 países de ranking de PIB per cápita y es en la actualidad la economía numero 20 por volumen de PIB, con una tasa de deuda pública de $22,79 \%$ del PIB. Según el Índice de Desarrollo Humano de las Naciones Unidas, que mide el progreso y el nivel de vida de los países, Arabia Saudí se encuentra en el puesto 40, por detrás de Israel (puesto

2 Saudi Arabia, Pre-crisis GDP level will be reached in 2022, Euler Hermes, en https://www.eulerhermes.com/en_CA/resources/country-reports/Saudi-Arabia.html 
19), España (puesto 25), Emiratos Árabes Unidos (puesto 31), y por delante de Bahréin (puesto 41), Catar (puesto 45), Omán (puesto 60) e Irán (puesto 70)3 .

La narrativa religiosa saudí y la fuerte economía del país, junto a su red de alianzas con terceros Estados llevan a Arabia Saudí a considerarse un valedor del mundo musulmán y un actor necesario para la estabilidad de la región en Oriente Medio, a pesar de que su inherente debilidad interna y sus contradicciones en política exterior debilitan su atractivo e impacto en la región. Los objetivos de la política exterior del reino saudita y sus fines dentro del convulso contexto regional se entremezclan con los intereses concretos de la dinastía Al Saud, que busca un equilibrio entre la defensa de los intereses nacionales tradicionales del rey Salmán con las innovaciones futuristas del Príncipe heredero Mohamed bin Salmán.

En este contexto, el presente artículo analiza los elementos religiosos, geopolíticos, y económicos que hacen que Arabia Saudí sea una potencia en Oriente Medio y que con el impulso del actual Príncipe heredero Mohamed bin Salmán está adquiriendo un nuevo perfil innovador. Conviene identificar, previamente, los fundamentos políticos-religiosos del actual Reino y analizarlos hasta sus últimas consecuencias, puesto que son la razón de ser de la política nacional y exterior saudí. Solo así se podrá analizar, a continuación, de forma detallada las complejas relaciones internacionales del Reino Saudí, dentro y fuera de la región, considerando en cada caso concreto los principales hitos históricos que marcan el devenir de una geopolítica cambiante, paradójica en algunos casos y sorprendentes en otros.

\section{Los fundamentos políticos de Arabia Saudí y su particular idiosincrasia}

\subsection{Un binomio indisoluble y constitutivo del Estado: el poder del monarca $y$ el wahabismo}

El Reino de Arabia Saudí como Estado moderno y soberano data de 1932, lo que significa que es de reciente creación, por lo que ciertos comportamientos, tanto internos como externos, responden a un nivel todavía poco evolucionado de la síntesis estatal. Cuenta con un poderoso aparato y sistema burocrático, sin embargo, su organización social y política están aún influenciadas por rasgos que responden más a la diversidad tribal ${ }^{4}$.

La actual Arabia Saudí no es un estado islamista radical ni violento, aunque en los últimos años están surgiendo algunos grupos radicales. De hecho, el Estado Islámico o Dáesh es un férreo defensor radical de la doctrina heterodoxa del islam sunní, aunque no se puede identificar a todo el wahabismo con el Dáesh ${ }^{5}$. El wahabismo sunní (o salafismo como les gusta llamarse a sí mismo a sus propios seguidores, puesto que es una de las manifestaciones más visibles hoy del salafismo ${ }^{6}$ ) sigue vigente como la única interpretación correcta de Corán y la tradición (sunna $)^{7}$ y sustenta y legitima el poder de la dinastía Al Saud. El wahabismo no es

\footnotetext{
${ }^{3}$ Conceição, Pedro: La Próxima frontera. El desarrollo y el Antropoceno, Informe sobre desarrollo humano 2020 , en http://hdr.undp.org/sites/default/files/hdr_2020_overview_spanish.pdf

${ }^{4}$ Yamani, Mai: “The two faces of Saudi Arabia,” Survival. Vol. 50, no 1 (February-March 2008), pp. 143-156.

${ }^{5}$ Es más, solo hay dos ciudadanos saudíes en las listas de personas y asociaciones o grupos que participan de forma directa con las acciones terroristas yihadistas y a quienes la UE impone sanciones concretas: Al-Nasser, Abdelkarim Hussein Mohamed, nacido en Al Ihsa (Arabia Saudí), nacional de Arabia Saudí y Al Yacoub, Ibrahim Salih Mohammed, nacido el 16.10.1966 en Tarut (Arabia Saudí), nacional de Arabia Saudí, según el anexo I de la Decisión (PESC ) 2020/1132 del Consejo, de 30 de julio de 2020 por la que se actualiza la lista de personas, grupos y entidades a los que se aplican los artículos 2, 3 y 4 de la Posición Común 2001/931/PESC sobre la aplicación de medidas específicas de lucha contra el terrorismo, y se deroga la Decisión (PESC) 2020/20.

${ }^{6}$ Echeverría, Carlos: "La dimensión ideológica del Islam y del Islamismo y su reflejo a lo largo de la historia", en Carlos Echeverría (coord.) (2028): Democracia e Islam, ¿una relación imposible? Comares, Granada, pp. 1-12, p. 10.

${ }^{7}$ En la actualidad existen dos grandes familias dentro del islam: los sunníes o partidarios de la traición (sunna) que constituyen en la actualidad un $90 \%$ de los musulmanes y los shíes o partidario de Ali, que no aceptan la
} 
una secta; es la corriente sunita mayoritaria y de carácter oficial en el reino saudita, aunque también está presente en el emirato catarí que no reconoce la validez de las otras interpretaciones del islam ni posibles disentimientos explicativos. Sus objetivos más importantes es la restauración de la verdadera fe y redirigir a los fieles hacia la práctica correcta $^{8}$. De ahí que el proselitismo de su fe sea otro de sus señas de identidad. Su profunda e intensa campaña de divulgación se ha impulsado tanto desde el propio Estado o bien a través de algunas de sus múltiples ONGs o entidades sostenidas con fondos estatales como la Liga Musulmana Mundial, la Asamblea Mundial de la Juventud Islámica o la Organización de Ayuda Islámica Mundial. De hecho, según el profesor Brahma Chellany, Arabia Saudí ha gastado alrededor de 200.000 millones de dólares en tal menester ${ }^{9}$, no solo en África, Oriente Medio y Europa, sino también en Asia donde diversos organismos de seguridad han venido exponiendo su preocupación por la expansión del wahabismo financiado por Arabia Saudita, radicalizando a grupos musulmanes tradicionalmente moderados para unirse al Daesh y otros grupos terroristas como Jemaah Islamiah, Abu Sayyaf, o el MILF. ${ }^{10}$ Según el presidente Barack Obama, la familia real saudí entregó miles de millones de dólares a estos clérigos radicales para que construyeran mezquitas y madrazas por todo el mundo sunita y "alentó un movimiento fundamentalista transnacional que despreciaba las influencias occidentales, sospechaba del flirteo saudí con Estados Unidos y servía como laboratorio para la radicalización de muchos jóvenes musulmanes: hombres como Osama Bin Laden, hijo de un importante hombre de negocios saudí cercano a la familia real, y los quince saudíes que, junto a otros cuatro radicales, planearon y ejecutaron los ataques del $11-\mathrm{S}^{\prime} .{ }^{11}$

El wahabismo organiza y gobierna el día a día de los sauditas, ya que insiste en la unidad entre religión y política, y esta indisoluble unión es el fundamento que legitima el poder de la dinastía Al Saud ${ }^{12}$. El monarca es el custodio oficial de las dos mezquitas sagradas de La Meca y Medina, desde que así lo estableció el rey Fahd en 1986, por lo que, desde entonces, los lugares santos adquieren un destacado carácter político, que enorgullece a los saudíes ${ }^{13}$. Su

tradición de los sunitas y que en la actualidad suponen un 10\% de los musulmanes. En el mundo sunní, la interpretación de la Sharia dio lugar a diversas escuelas. Pero no son escuelas religiosas o exegéticas, sino jurídicas, porque explican cómo debe interpretarse la ley islámica y con ellas surgió la jurisprudencia islámica. Las cuatro escuelas son: 1) la hanafi, llamada así por su fundador Abu Hanifa (699-767d.C), admite el valor de la opinión racional, reconocen la idea del individuo responsable; 2) escuela maliki fundada en Medina, a finales del s. VIII dC. Tras una exhaustiva recopilación de la tradición, de la práctica religiosa y del derecho consuetudinario de Medina, entendido que allí se conservaba la sunna original, declara la importancia de las costumbres y usos locales: 3) escuela safii, nacida en Gaza fue impulsada por Al-Safíi, (767-820dC), y nació como reacción a la escuela maliki, ya que Al-Safii consideraba que no era seguro basarse en sólo en una ciudad islámica, sino que la jurisprudencia debía basarse en los dichos, hadices, del Profeta; y 4) la escuela hambali es la más tardía en el tiempo, fundada por Ahmed bin Hanbal (780-855 dC). Es la más estricta de todas las escuelas, ya que reduce la interpretación del Corán y la sunna al sentido literal e insiste en la unidad entre religión y política. En esta escuela hambali se inspira Abdel Wahhab, reformador del s. XVIII, que ha dado lugar al movimiento wahabí, que es el islam impuesto en Arabia saudí.

${ }^{8}$ Baskan, Birol and Wright, Steven: "Seeds of change: comparing state-religion relations in Qatar and Saudi Arabia” Arab Studies Quarterly. vol.33, n 2 (Spring 2011), pp. 96-111, pp. 96-98.

${ }^{9}$ Echeverría, op. cit., p. 22

${ }^{10}$ Lin, Christina: "ISIS and the Saudi Wahhabi Threat to Asian Security", ISPSW Strategy Series: Focus on Defense and International Security, no 365 (July 2015), pp. 1-5.

${ }^{11}$ Obama Barack (2020): Una tierra prometida, Barcelona, Debate, 2020, p.434

12 "Saudi Arabia Backgrounder: Who are the Islamists?", International Crisis Group, Middle East and North Africa, 21 September 2004, en https://www.crisisgroup.org/middle-east-north-africa/gulf-and-arabianpeninsula/saudi-arabia/saudi-arabia-backgrounder-who-are-islamists.

${ }^{13}$ A pesar de los dos grandes reveses históricos sufridos en la cuna del islam: en septiembre de 2015, se estrelló una grúa contra la Gran Mezquita de la Meca que causó la muerte de más de cien personas. Las autoridades saudíes alegaron que las causas del indecente se debieron a las malas condiciones meteorológicas. Menos de dos semanas después, durante el hach anual, una estampida costó la vida a más de 2.000 personas, según algunos informes, aunque las autoridades saudíes han insistido en mantener el número de víctimas oficial en 769. Muchas de ellas 
forma de gobierno es la monarquía absoluta que, en comparación con otras monarquías de la región - como la jordana o Bahréin -, está basada en una interpretación estricta de las reglas que gobiernan una sociedad islámica. El Corán es su Constitución, carece de Parlamento propiamente dicho, y los partidos políticos y sindicatos están prohibidos, aunque existen asociaciones sin ánimo de lucro y organizaciones empresariales. El Poder Ejecutivo reside en el Rey, que debe ser descendiente de Abdulaziz bin Saud, y es quien nombra y dirige el Consejo de Ministros. Los ministros son responsables ante el Monarca, el cual puede vetar cualquier decisión adoptada por el Consejo en un plazo de treinta días. En la práctica, todos los poderes del Estado emanan del Rey. En esta forma de Estado resulta casi imposible que exista una oposición política fuerte, más allá de las reclamaciones de los chiítas del este o algunos grupos salafistas. Ni siquiera el temido efecto dominó de las primaveras árabes consiguió promover algunas estructuras o partidos políticos opositores al Gobierno, como ocurrió en otros países de su entorno, como Egipto, Siria o Túnez. Sin embargo, la deficiente actuación de las autoridades saudíes ante las graves inundaciones sufridas en Yeda en 2009, provocó las primeras movilizaciones y campañas contra la corrupción del régimen y puso en evidencia la manifiesta falta de libertades y derechos civiles. Yeda es la ciudad más cosmopolitita y abierta del Reino de Arabia y de vital importancia, ya que además de ser la segunda ciudad más poblada del país, su puerto marítimo es el segundo más grande y el más concurrido del mundo árabe (después del puerto de Jebel Ali en Dubai). En sus calles se entremezcla la modernidad y la historia, puesto que es el punto de partida del peregrinaje a ciudades como La Meca y Medina. Desde aquellas revueltas, el descontento social se hace notar con más fuerza que nunca ${ }^{14}$, cuestión que sin duda preocupa a las autoridades y, en particular, al actual príncipe heredero Mohamed bin Salmán, ya que Yeda es el exponente más claro del aperturismo social y político del régimen saudita y es, precisamente, la imagen oficial del Arabia Saudí moderno que presenta la Corona a sus socios occidentales ${ }^{15}$.

El poder real de la familia Saud es de tal envergadura que la sucesión al trono no es una cuestión baladí, ni de mera imagen de representación pública internacional del Reino. La Corona es un elemento constitutivo del Reino y del poder de la dinastía Saud. La sucesión al trono es una cuestión de Estado que exige una acción política, que no siempre se ha realizado de forma pacífica. En estos 89 años de existencia del Reino, ha habido siete monarcas y, en ocasiones, la sucesión se ha visto ensombrecida por tensiones y especulaciones internas en la familia Saud, e incluso con derramamiento de sangre. En 1964, el rey Saúd bin Abdalaziz se vio obligado a abdicar y el nuevo monarca, el rey Faisal fue asesinado por su sobrino en 1975, el príncipe Faisal ibn Musaid, por motivos familiares de lucha por el poder que no políticos, ya que en aquel momento el monarca depuesto gozaba de prestigio internacional y el Reino saudí se consolidaba como referente en el mundo islámico.

En 1982, tras la muerte del rey Jalid, sube al trono Fahd quien gobernará hasta 2005, modernizando el Reino con diversas reformas no muy populares, la creación de un Consejo Consultivo y la adopción de las tres Leyes Básicas de 1992, que, en términos generales, suponen el nuevo marco jurídico del poder estatal. La libertad de religión no está prevista por la ley, que

(al menos 465) eran iraníes. Irán, además de cuestionar la capacidad de Arabia Saudí para organizar la peregrinación a La Meca, le acusó al país vecino de secuestrar a su antiguo embajador en el Líbano, que sigue desaparecido desde que ocurrió la tragedia, cuando realizaba la peregrinación a la ciudad santa con un nombre falso. Huelga decir que esto no ha hecho más que tensar, en mayor medida si cabe, las malas relaciones entre los dos países.

${ }^{14}$ Dorsey, James M.: "Saudi crackdown raises specter of wider dissent", The Begin-Sadat Center for Strategic Studies, BESA Center Perspectives Paper nº 635, 6 November 2017, en https: https://besacenter.org/saudi-crackdown/

15 Hammond, Andrew: "Liberal pockets in Saudi Arabia's rigid state", Reuters, 19 August 2008, en https://www.reuters.com/article/us-saudi-econcities-society-idUSL22101098020080820 
criminaliza a "cualquiera que desafíe, directa o indirectamente, la religión o la justicia del Rey o Príncipe heredero". La ley penaliza además "la promoción de ideologías ateas en cualquier forma", cualquier intento de poner en duda los fundamentos del islam, las publicaciones que "contradicen las disposiciones de la ley islámica" y otros actos, incluido el culto público no islámico, la exhibición pública de símbolos religiosos no islámicos, conversión de un musulmán a otra religión, y proselitismo por parte de un no musulmán. En la práctica, existe una tolerancia muy limitada hacia el ejercicio religioso privado no islámico, pero las prácticas religiosas en desacuerdo con la forma de islam sunita promovida por el Gobierno siguen siendo vulnerables a la detención, el acoso y, para los no ciudadanos, la deportación.

En 1993 se fundó en Riad el Comité de Arabia Saudí para la defensa de los Derechos Legítimos (CDDL), cuyo objetivo era eliminar las injustica y restablecer los derechos de los individuos con arreglo a los principios de la sharía, y su interpretación según la escuela Hanbali de jurisprudencia islámica sunita. Este Comité vela por la integridad de la doctrina oficial del wahabismo y con el tiempo se convirtió en una fuente de información sobre la corrupción del Gobierno, las violaciones de los derechos humanos, la tortura y el encarcelamiento de disidentes del país. Lógicamente su actividad resultaba incómoda para la corona. Pero ni las reformas, ni el Consejo Consultivo lograron acallar las voces de la disidencia islámica que seguía reclamando mejoras de los servicios de bienestar social, escuelas, hospitales y otras reivindicaciones ${ }^{16}$, que perduraban desde 1990 y que hoy llamaríamos feministas básicas, como, por ejemplo, que se elimine la prohibición de conducir que pesaba sobre las mujeres ${ }^{17}$, cuestión estrella de entre los elementos de la agenda Visión 2030. Durante el reinado de Fahd se desarrolló una política regional sobre tres premisas fundamentales: 1) que cualquier intervención extranjera en la región debía contar con el beneplácito o consulta de Arabia Saudí; 2) que cualquier hecho o crisis local que pudiera poner en peligro el liderazgo saudita requeriría la intervención inmediata; y 3) se estableció un orden de prioridades, según el grado de afectación al orden regional y primacía saudita del acontecimiento. Sin duda, durante su reinado, la política regional de Riad persiguió la consecución y mantenimiento de los objetivos su liderazgo regional ${ }^{18}$, que necesariamente pasaban por la defensa de cualquier situación favorable a sus intereses y su propia seguridad nacional.

El actual rey Salmán bin Abdulaziz ostenta el poder desde 2015, si bien no era el heredero oficial de la casa Saud, hasta que fue nombrado en junio de 2012, tras la muerte del príncipe heredero Naif bin Abdulaziz Al Saud. En aquel momento, los líderes políticos del mundo entero acudieron en masa a Riad para rendir homenaje al nuevo rey, obviando la dureza del Reino y las paradojas saudíes del pasado. Incluso Barack Obama interrumpió un viaje a la India para saludar al nuevo rey ${ }^{19}$. Su reinado está resultando, no obstante, continuista en algunos aspectos y renovador en otros en relación con la política de su antecesor y medio hermano. Sus decisiones de gobierno manifiestan su firme compromiso para que los sauditas

\footnotetext{
${ }^{16}$ Al-Rasheeed, Madawi (2003): Historia de Arabia Saudí, Cambridge, Cambridge University Press, p. 246.

${ }^{17}$ Este ejemplo no es baladí; sino que es una muestra la escasa valoración efectiva de los derechos civiles de la población o la falta de igualdad de oportunidades para determinados grupos, en particular, las mujeres. Véase, en general, Teitelbaum, Joshua: "Saudi Arabia and the new strategic landscape," Middle East Review of International Affairs, vol. 14, no 3 (September 2010), pp. 38-44; Seilkay, May, Roodsaz, Rahil y Van Egten, Corine: “The situation of the women in the Gulf States”, Directorate General for Internal Policies, European Parliament, 2014, en particular, pp. 175-195

${ }^{18}$ Wilson, Peter W. y Graham, Douglas F. (1994) Saudi Arabia. The coming storm, New York, M.E. Sharpe, pp. 131-133.

19“'An unholy pact", The Economist, 25 January 2015, en

https://www.economist.com/leaders/2015/01/29/an-unholy-pact
} 
no pierdan su supremacía en la región ${ }^{20}$, aunque para alcanzarlo tenga que enfrentarse a alguno de sus hermanos musulmanes, como Catar. Su doble estrategia - de continuidad y renovación política - no ha conseguido frenar las tensiones familiares por el poder. Cuando el rey Salmán accedió al trono nombró a su sobrino Mohamed bin Nayef príncipe heredero y ministro de Interior, secundando así los deseos de su antecesor. Un par de años más tarde, en 2017 lo sustituye por su propio hijo, Mohammed bin Salmán bin Abdulaziz Al Saud, quien además ostenta varios cargos de gobierno, como vicepresidente primero del Consejo de Ministros, ministro de Defensa y presidente del Consejo de Asuntos Económicos y de Desarrollo, del Consejo de Asuntos Políticos y de Seguridad, y del Consejo Supremo de Saudi Aramco que es la empresa estatal de petróleo y gas. El rey Salmán disolvió varios comités y consejos de su antecesor y, en su lugar, estableció sólo dos: el Consejo para Asuntos Políticos y de Seguridad, al frente del cual nombró al vicepresidente y Príncipe Heredero, y el Consejo para Asuntos Económicos y de Desarrollo, dirigido por el ministro de Defensa. Ambos fueron vinculados al Consejo de Ministros.

Dado el fundamento político-religioso del Estado saudí, la dinastía Saud ha asumido tradicionalmente un discurso arabista y antijudío estricto y su gobierno no ha dudado en auxiliar y apoyar a aquellos actores políticos y religiosos con los que comparte un fundamentalismo parecido, rehuyendo de alentar a aquellos otros que tienen un programa más moderado, secular o incluso fuera del sunnismo. Este planteamiento se ha manifestado a lo largo de los años y en todos los monarcas sauditas, como por ejemplo frente al panarabismo de Nasser en Egipto o para frenar las tensiones con los ayatolás iraníes o los Hermanos Musulmanes en Egipto con el Gobierno de Morsi ${ }^{21}$. Durante las primaveras árabes, Riad solo apoyó a aquellos levantamientos con elementos afines a los intereses de la Casa de Saud y si comulgaban con los dogmas wahabitas. En esta misma línea, actualmente, los sauditas dan sustento directo a las partes salafistas de la oposición siria, ya que quieren evitar que se extienda el proceso democrático en el mundo árabe impulsado por la primavera árabe y lo hacen financiando la compra de armas para la oposición. Igualmente apoya junto con Rusia, Egipto, Emiratos Árabes Unidos y Jordania a las facciones libias más conservadores, en concreto, al general Khalifa Haftar que ostenta el mando miliar del autoproclamado Ejército Nacional Libio (ELN) y que controla gran parte del país, en contra de las posturas oficiales de la ONU y sus aliados. Mientras tanto, en el ámbito interno, el rey Salman y el príncipe heredero continúan con su estrategia de cercenar y reducir el protagonismo de ese islam político que aspira a ser más democrático.

El actual poder estatal y la administración pública se ejercen siguiendo el esquema de un Estado moderno, con un Consejo de Ministros presidido por el Rey, Ministerios organizados por áreas políticas, un procedimiento legislativo con la particularidad de que la función de la Cámara es meramente consultiva - aun así, importante-, y una Administración de Justicia teóricamente independiente. Ahora bien, en la lógica de una monarquía absoluta, donde la jefatura del Estado y el poder de los principales ministerios se reserva para la familia Saud, no sorprende que confluyan los intereses de la política nacional y de las relaciones exteriores con los intereses de la dinastía. Esto significa que los que intereses elementales intrínsecos a la propia naturaleza del Estado saudita conlleva que - por una parte - la familia Saud ocupe los principales puestos del aparato estatal, con especial concentración en los ámbitos internacionales, seguridad, defensa y organización territorial, considerados como "vitales"; y por otra - que los representantes religiosos se encargan tanto de las cuestiones de fe, como de

\footnotetext{
${ }^{20}$ Cuadro, Mariela: "Nuevo rey y cambios en la política saudí: de la amenaza de la Hermandad Musulmana al peligro iraní", Anuario de Relaciones Internacionales, Departamento de Oriente Medio, 2015, en https://www.iri.edu.ar/publicaciones_iri/anuario/anuario_2015/Demo/AS\%20por\%20MC.pd

${ }^{21}$ AL Qassemi, Sultan: "Qatar's Brotherhood Ties Alienate Fellow Gulf States”, Al Monitor.

23 January 2013.
} 
la justicia y la educación primaria, pero desarrollando una estrategia educativa panislámica sunní. Esta estrategia contempla que todos los estudiantes de las escuelas públicas de todos los niveles reciben instrucción religiosa obligatoria basada en el islam sunita, según la escuela de jurisprudencia Hanbali; mientras que las escuelas privadas no pueden desviarse del plan de estudios religiosos oficial aprobado por el Gobierno, incluidas las escuelas privadas internacionales que también están obligadas a enseñar a los estudiantes saudíes y musulmanes de otras nacionalidades un curso de estudios islámicos. Sin embargo, los estudiantes no musulmanes y no sauditas pueden optar por un curso sobre civilización islámica o cursos alternativos en lugar del plan de estudios diseñado para los estudiantes sauditas. Esta distribución de poderes manifiesta la importante labor del proselitismo saudí en su propio Estados, planificado por el monarca y ejercido a través de sus múltiples $\mathrm{ONGs}^{22}$.

La Corona saudí defiende con firmeza su status quo y el mantenimiento del orden establecido $^{23}$, aunque prometa cambios políticos y reformas graduales en la represión y persecución sistemática de sus opositores, al mismo tiempo que intenta equilibrar las presiones entre los sectores religiosos más conservadores y rigoristas con las aspiraciones aperturistas de los grupos nacionales de tendencia liberal ${ }^{24}$. El rey Fadh ya había otorgado ciertas licencias religiosa en los barrios mixtos de residentes sunitas y chiítas, que permitió además que todas las mezquitas, incluidas las mezquitas chiítas, utilizar el llamado sunnita a la oración. En cambio, en áreas predominantemente chiítas como Qatif, y en algunas áreas chiítas de la gobernación de alAhsa en la provincia oriental, las autoridades permiten que las mezquitas chiítas usen la variante chiíta Doce del llamado a la oración. A pesar de que el sustrato religioso del terrorismo yihadista parece encontrarse en el islam sunní wahabí salafista, la monarquía saudita llegó a ser un objetivo más del terrorismo yihadista por su asociación con países occidentales. Al menos esa fue la explicación oficial del Gobierno ante los atentados en varios barrios residenciales y diplomáticos de Riad en mayo de 2003 o el atentado contra el príncipe Mohammed bin Nayef en 2009. Pues, en la lógica de los agentes extremistas, como el Daesh o Al Qaeda, el régimen saudita y la familia real, simbolizan un ejemplo de apostasía y herejía, considerados así por ser unos falsos creyentes que atienden solo a sus propios intereses y a los de potencias extranjeras $\mathrm{y}$, en consecuencia, cada vez son más recurrentes las acusaciones hacia los dirigentes sauditas de ser valedores directos o indirectos de grupos terroristas.

Los principios políticos tradicionales islámicos, fundamentados en la familia islámica, la jerarquía, y los derechos y deberes de los musulmanes tienen su fundamento teórico hoy en día en las tres Leyes Básicas de 1992, que son las que define al país y en las que se establece que las fuentes del Derecho (sharía) son el Corán y la tradición del profeta (sunna). Este marco jurídico deja escaso espacio para los derechos políticos individuales o la disidencia política. Si bien, el impacto de la brecha generacional de la población saudí se aprecia particularmente en los últimos años, ya que las generaciones más jóvenes comienzan a introducir ciertos hábitos en el ámbito familiar y social, alejados de las costumbres y tradiciones más arraigadas entre los más mayores. Estas circunstancias están obligando a la monarquía a hacer frente a nuevos y emergentes desafíos como la discriminación de la mujer, la desigualdad, la pobreza o las expectativas sociales y laborales de las nuevas generaciones ${ }^{25}$, por lo que el Gobierno de forma

\footnotetext{
${ }^{22}$ Shane, Scott. "Saudis and Extremism": 'Both the Arsonists and the Firefighters", New York Times, 26 August 26, 2016.

${ }^{23}$ Priego, Alberto: "La Primaveras Árabes: la influencia de Catar y sus relaciones con los Estado del Golfo", UNISCI, no 39 (octubre 2015), pp. 233-253, p. 234

${ }^{24}$ Sobre los grupos más aperturistas, Hammond, Andrew: "Liberal pockets in Saudi Arabia's rigid state", Reuters, 19 August 2008, en

http://www.reuters.com/article/us-saudi-econcities-societyidUSL22101098020080820

${ }^{25}$ La desigualdad social es un problema estructural en el reino saudita, que viene dada por una distribución de la riqueza inequitativa. Los datos desprendidos por el Gobierno suelen estimar que el número de sauditas en
} 
prudente accede a ciertos avances significativos en la mejora de los derechos sociales y económicos, pero sin transigir en otras cuestiones más medulares sunníes. Así, por ejemplo, ya se han eliminado algunos aspectos del sistema de tutela masculina sobre la mujer, que puede acceder al permiso de conducir o incorporarse al mercado laboral ${ }^{26}$. Se permite el voto a las mujeres en las elecciones desde diciembre de 2015 y se les reserva determinados espacios en las instituciones políticas. Persisten, no obstante, otras cuestiones sociales más polémicas, desde el punto de vista de la sharía, ya que la mujer requiere del permiso del hombre para viajar o que la entrada en edificios públicos sea distinta para ambos géneros. Pero ante esta situación, el Parlamento Europeo, por ejemplo, pide a las autoridades saudíes que ratifiquen el Pacto Internacional de Derechos Civiles y Políticos y retiren las reservas formuladas en relación con la Convención sobre la Eliminación de Todas las Formas de Discriminación contra la Mujer y ratifiquen el Protocolo Facultativo a esta Convención de modo que las mujeres saudíes puedan disfrutar plenamente de los derechos consagrados en la Convención, así como que pongan fin a los matrimonios infantiles, a los matrimonios forzosos y al código de vestimenta obligatoria para las mujeres; insta a Arabia Saudí a que curse una invitación permanente a todos los titulares de procedimientos especiales del Consejo de Derechos Humanos de las Naciones Unidas para que visiten el país. ${ }^{27}$

El aperturismo del rey Salmán en relación con las instituciones públicas se refleja en la composición del Consejo Consultivo (Majlis Al-Shura). Este órgano asesor del monarca está compuesto por 150 miembros, de los cuales 30 son mujeres, desde que entró en vigor el Decreto Real de enero de 2013 que impone una cuota femenina del 20\% de sus miembros; son designados libremente por el Rey por un periodo de cuatro años entre personalidades destacadas de la sociedad saudí con el fin reflejar la diversidad y distintas sensibilidades. El rey Salman bin Abdulaziz Al Saud ha buscado en la elección de sus miembros el equilibrio entre la tendencia aperturista y la preocupación por la integridad del wahabismo.

Estos ejemplos muestran cómo la Corona Saud se encuentra en la tesitura de ir solventado las fricciones sociales y políticas internas, combinando con prudencia la inserción progresiva de reformas liberales, sociales y económicas, propias de un Estado moderno del siglo XXI, pero con la cautela necesaria para no traicionar sus valores tradicionales wahabís, que constituyen y sustentan su identidad nacional. De lo contrario, si el sectarismo derrota a los Saud, su reemplazo no sería un buen parlamento democrático, como se promueve teóricamente en Occidente, sino un buen caos nacional y regional, basta con mirar a Libia e incluso, se correría el alto riesgo de llegar a un caos nacional saudí de corte, incluso, yihadistas.

\subsection{La geopolítica del petróleo saudí en la región y en el mundo}

El binomio "monarca y wahabismo" se traduce en unos objetivos políticos que gobiernan la nación y su acción exterior, como son: 1) defender la soberanía nacional y unidad territorial; 2) asegurar la estabilidad interna del país frente a cualquier factor de tensión; 3) alcanzar el reconocimiento de la comunidad internacional, tanto como nación soberana y como figura referencia de la región y del mundo musulmán; 4) proteger los valores islámicos y el dogma del wahabismo, que es elemento fundacional del Estado y uno de los pilares sobre los que se apoya el poder de los Saud; y 5) la inquebrantable lealtad al monarca, descendiente del

condición de pobreza está en torno a un 14\%. Aunque la mayoría de análisis internacionales elevan el número de sauditas que viven por debajo del umbral de la pobreza. Aproximadamente 4 millones de sauditas viven por debajo de esta línea y 1,6\% en condiciones de pobreza extrema., Sobre estas cuestiones, Baker, Aryn: "Down and out in Saudi Arabia”, Time. 3 June 2013, en http://content.time.com/time/subscriber/article/0,33009,2144028-1,00.html ${ }^{26}$ Al-Rasheed, Madawi. (2013): A most masculine state. Gender, politics and religion in Saudi Arabia. New York, Cambridge University Press.

${ }^{27}$ Resolución del Parlamento Europeo de 14 de febrero de 2019, sobre los defensores de los derechos de las mujeres en Arabia Saudí (2019/2564(RSP)) (2020/C 449/17), punto 15. 
fundador, y a su autoridad incuestionable sobre toda la nación. Todos estos objetivos están estrechamente relacionados entre sí, cuya consecución exige a las autoridades saudíes una estrategia regional adaptada a los nuevos tiempos, que no puede depender exclusivamente del petróleo, sino que requiere una diplomacia internacional coherente, aunque resulte altamente compleja y, en ocasiones, incluso poco creíble.

Tradicionalmente, la Casa Saud ha defendido su identidad nacional en la región conteniendo las amenazas a su propia seguridad, aprovechando política y diplomáticamente su riqueza natural y las grandes reservas de crudo ${ }^{28}$. Los elevados precios del barril de crudo, al menos tras las guerras de las guerras de Afganistán (2001) e Irak (2003), permitieron al monarca saudí desarrollar una política exterior de reafirmación nacional y de renovación tecnológica de sus fuerzas armadas, como consecuencia de convertirse en un socio necesario de Occidente, más en particular para los Estados Unidos, pero también para la estabilidad de la región. La riqueza petrolífera es fuente de financiación de alianzas con grupos insurgentes y "antiinsurgentes" en Iraq, Bahréin, Siria o Yemen ${ }^{29}$, y una herramienta política para sofocar los focos de inseguridad e incertidumbre próximos a su territorio ${ }^{30}$, sobre todo como contrapeso del crecimiento de la influencia iraní en la región. A fecha de hoy, y a pesar de la disminución de sus exportaciones en 2020, Arabia Saudí sigue liderando el apoyo económico y logístico a determinados grupos opositores que combaten en Siria y en Yemen, donde la casa Saud es el principal respaldo internacional del presidente yemení al-Hadi, que le sirve como un instrumento más en su particular "guerra fría" contra Irán. Pero la esencia de la geopolítica del petróleo saudí consiste en financiar también programas y empresas de muy diversa índole en terceros Estados con el fin de atraer hacia su zona de influencia a otros Gobiernos de la región y del planeta con una muy clara finalidad: evitar así que se vean obligados a acudir Irán. Esta geopolítica se extiende más allá del Golfo hacia Asia-Pacífico, en concreto, a China y Corea del Sur y, en menor medida, hacia Europa, en concreto, a Francia, a pesar de que el precio del barril en la OPEP ya no es lo que era en $2003^{31}$.

La empresa estatal Aramco es el buque insignia del crudo saudí, que controla la mayor parte de la red de hidrocarburos y reservas de su territorio saudita, y su producción está directamente gobernada por las directrices del Príncipe heredero dese su puesto de presidente del Consejo Supremo de Saudi Aramco. Un dato muy significativo del papel primordial de Aramco en la geopolítica saudí fue el atentado sufrido en septiembre de 2019, con dieciocho drones y siete misiles teledirigidos de forma simultánea contra las instalaciones de la petrolera en Abqaiq y dos de sus pozos situados a unos $80 \mathrm{~km}$ de distantica, en Khurais. Las consecuencias del ataque fueron de tal envergadura que supuso el cierre total de la petrolera durante 9 meses, por lo que la producción del crudo se redujo en un $75 \%$. Los ataques fueros revindicados por un grupo rebelde hutíe de Yemen, el autodenominado Ansar Allah (partidarios de Dios) que pertenece a una rama del islam chiíta, el zaidismo, que desde la clandestinidad combaten para recuperar el gobierno del país, contando con el apoyo logístico, político y financiero de Irán. En su comunicado, el grupo Ansar Allah amenazó con "operaciones más dolorosas", si Arabia Saudí continuaba con sus ataques en Yemen, pero que cesarían en sus ofensivas si Riad retiraba sus tropas de Yemen. La gravedad del ataque paralizó temporalmente

\footnotetext{
${ }^{28}$ Hernández Martínez, David (2020): El reino de Arabia Saudí, Madrid, Catarata, pp. 40-48.

${ }^{29}$ Jones, Toby Craig. (2010): Desert Kingdom. How oil and water forged modern Saudi Arabia. London, Harvard University Press.

${ }^{30}$ Jahner, Ariel: "Saudi Arabia and Iran: The struggle for power and influence in the Gulf", International Affairs Review. vol. XX, nº 3 (Spring 2012), pp. 37-50, pp. 45 y 46.

${ }^{31}$ Aunque hay que destacar, que en los últimos doce meses el precio del barril de petróleo de la OPEP ha aumentado un 91,44\%. Desde el año 2003, hasta ahora, el precio más alto ha sido al que ha cotizado el barril de crudo fue de 140, 73 \$ el 3 de julio de 2008, mientras que en el 22 de abril de 2020 - en plana pandemia mundial - su precio más mínimo no superó los 12,22 \$.
} 
a la petrolera, pero tan solo un año después tras su parcial privatización y salida a bolsa, en la Bolsa de Tamazul, sus acciones han incrementado su valor en torno al 10\%, a pesar de coincidir con la peor caída de la demanda de crudo por la covid-19.

La riqueza petrolífera saudí ha impulsado, por una parte, la compra de armamento de alta tecnología a los Estados Unidos con lo que el reino saudí ha ido adquiriendo gran capacidad de defensa militar ${ }^{32}$, aunque las exportaciones saudíes en ocasiones se han enfrentado a ciertos obstáculos, lo que llevó a algunos expertos a alertar de su posible bancarrota ${ }^{33}$; sin duda, la situación actual ha mejorado. Esta previsión, por otra parte, resultaba muy poco creíble a la luz de las millonarias inversiones de Mohamed bin Salmán fuera de la Península Arábiga. A pesar de las dificultades económicas, hay que advertir que, en 2020 el gasto de defensa sitúa a Arabia Saudí en el noveno lugar en el ranking mundial, con 48.500 millones de dólares. De acuerdo con el Informe del SIPRI sobre el comercio mundial de armas en el período 2016-2016, Estados Unidos ha sido el principal suministrador de sistemas de armas a Arabia Saudita con el 79\% seguido del Reino Unido con el 9.3\% y de Francia con el 4\%. ${ }^{34}$ España, entre 2011 y 2019, ha sido el cuarto exportador tras Francia. Disminuyó sus exportaciones en el segundo semestre de 2018, pero a partir de 2019 incrementó sus exportaciones ${ }^{35}$. Sin embargo, a pesar del esfuerzo en la inversión en medios militares de defensa, resulta poco probable que esta nueva herramienta político-militar del monarca Salmán sirva para poder inclinar la balanza del poder regional entre Riad y Teherán a favor del primero.

Por otra parte, la riqueza petrolífera saudí ha impulsado también importantes acuerdos de inversiones con países que atraviesan situaciones internas delicadas, por causas especificas muy variopintas según cada caso concreto, que Arabia Saudí aprovecha para "afianzar alianzas amistosas", ya sea para consolidar formalmente a la familia Al Jalifa en Bahréin, ya sea para apoyar al general Al Sisi en Egipto. Pero, sobre todo, la estrategia de inversiones extranjeras de Arabia Saudí - impulsada por el Príncipe Heredero - mira más allá de la región y no teme invertir grandes sumas millonarias en su fondo soberano de inversión, el llamando Fondo de Inversión Público (PIF por sus siglas en inglés), que, si bien desde sus orígenes en 1971 financia proyectos estratégicos nacionales, para mejorar la competitividad de diversos los sectores económicos y atraer empresas extranjeras y conocimiento a Arabia Saudí, en 2018, se marca nuevos objetivos y comienza poco a poco a invertir en el exterior, para que en 2030 la mitad de sus inversiones estén en el extranjeros.

\footnotetext{
${ }^{32}$ Desde la firma del acuerdo entre Estados Unidos y Arabia Saudí, en mayo de 2017, la administración norteamericana aporta \$ 110 mil millones para perseguir la modernización de las Fuerzas Armadas de Arabia Saudita. Los Estados Unidos obtiene \$ 126.6 mil millones en ventas activas de gobierno a gobierno con Arabia Saudita bajo el sistema de Ventas Militares Extranjeras (FMS). Las ventas de FMS notificadas al Congreso incluyen: sistemas antimisiles de defensa de área de gran altitud terminal (THAAD); Patriot Advanced Capability-3 sistemas de defensa aérea; apoyo de seguimiento para la Real Fuerza Aérea Saudita; Carrode combate M1A2 Abrams; Vehículos de ruedas multipropósito de alta movilidad (HMMWV); Vehículos blindados ligeros; Aviones F-15SA, C130J y KC-130J; Helicópteros AH-64D Apache, UH-60M Blackhawk, AH-6I Light Attack, MH-60R Multi-Mission y CH-47F Chinook; Naves de combate de superficie multimisión; Lanchas patrulleras Mark V; Modernización del Sistema de Control y Alerta Aerotransportada (AWACS); Sistema de armas Phalanx Close-In; modernización de la Guardia Nacional de Arabia Saudita y misiles Javelin y TOW-2B. Véase. U.S. Security Cooperation with Saudi Arabia, State Department, 20 January 2021, en https://www.state.gov/u-s-security-cooperation-with-saudi-arabia/

${ }^{33}$ Leyland, Adam. "Saudi Arabia could be bankrupt within five years, IMF predicts" The Independent, 24 October 2015, en http://www.independent.co.uk/news/world/middle-east/saudi-arabia-could-be-bankrupt- within-fiveyears-imfpredicts-a6706821.html

${ }^{34}$ Wezeman Pieter D.; Kuimova Alexandra and Wezeman Siemon T.: "Trends in International Arms Transfers, 2020” en https://sipri.org/sites/default/files/2021-03/fs_2103_at_2020.pdf

35 "Dispatch on Spanish Arm Sales to the Gulf Region", ADHRB en

https://www.adhrb.org/2020/08/dispatch-on-spanish-arm-sales-to-the-gulf-region/; "Spanish Arms Sales to Saudi Arabia Increased Under Sánchez", EuroWeekly, 26 June 2020; en

https://www.statista.com/statistics/1210951/saudi-arabia-share-of-arms-imports-by-supplier- country/
} 
El Fondo de Inversión de la petro monarquía saudí se nutre, entre otras fuentes, de la gestión de los ingresos de Aramco. Además, participa en tres grandes gigantes petroleras como son BP, Total S.A. y Royal Dutch Shell; dos bancos estadounidenses, como el Citigroup y Bank of America y en muchas otras empresas muy conocidas mundialmente como Boeing, Facebook, Disney, Uber, Marriott y Starbucks. El objetivo del PIF es convertir a Arabia Saudí "en una potencia inversora mundial y en un inversor de gran impacto, que permita la creación de nuevos sectores y oportunidades que conformen la futura economía mundial, a la vez que impulse la transformación económica de Arabia Saudí”36. Tanto el ministro de Inversiones saudi Khaled al Faleh, como el gobernador del fondo soberano saudí, Yasir al Rumayyan han indicado en repetidas ocasiones que su intención es "invertir activamente a largo plazo para maximizar los beneficios sostenibles, ser el socio inversor preferido para las oportunidades mundiales y permitir el desarrollo económico y la diversificación de la economía saudî”. Con estas premisas, la riqueza petrolera saudí ya ha llegado hasta Silicon Valley y, de forma indirecta, también a las inversiones en tecnología mediante otro fondo masivo establecido con SoftBank de Japón. También España aspira a beneficiarse del Fondo saudí, desde que, en febrero de 2021, Mohamed bin Salmán anunció que Aramco sacará nuevas operaciones de venta pública de acciones en los próximos años y que España quiere aprovechar para la recuperación post pandemia. Según Bin Salmán, el PIF aumentará su capital hasta los 1.100 millones de dólares. Y ese dinero se invertirá no solo en el país, sino también en el extranjero ${ }^{37}$.

Además, desde el ingreso de Arabia Saudí en la Organización Mundial del Comercio (OMC) en 2005, el clima de inversión extranjera en el reino saudí mejoró de forma sustancial el atractivo de sus reservas de crudo y es desde entonces - sin duda - un potente imán para atraer inversores europeos. Bien conocido es el ya famoso AVE a La Meca adjudicado en 2012 gracias a la mediación del Jefe del Estado Español al consorcio liderado por Renfe y Adif con un proyecto que alcanzó los 6.700 millones de euros y que impulsó la "marca España" en plena recesión, y a pesar de las muchas complicaciones nacionales variopintas que todavía acarrea ${ }^{38}$. Otra de las tensiones internas del actual Gobierno de España en relación con los negocios en Arabia Saudí gira en torno al deporte, aunque en el fondo lo que preocupa no es el deporte, sino la crítica situación social en la que viven las mujeres en el país árabe, pero que en esta ocasión se manifestaron de nuevo con ocasión del fútbol en 2019. La Federación Española de fútbol trasladó la supercopa a Arabia Saudí para las tres próximas temporadas por un valor de 120 millones para el fútbol español. Ningún representante del Gobierno acudió al estadio Rey Abdullah de Yeda donde se celebró la primera edición de 2020; mientras que la segunda cita se ha celebrado en nuestro país por las restricciones del coronavirus y se mantiene el acuerdo de volver a la Península Arábiga, cuando sea posible ${ }^{39}$. Más recientemente, el grupo de infraestructuras Acciona, en consorcio con RTCC, se adjudicó en diciembre de 2020 el

\footnotetext{
${ }^{36}$ Rodríguez, Ana: "Arabia Saudí invierte más de 7.700 millones de dólares en algunas de las empresas más conocida del mundo", Atalaya, 18 de mayo de 2020.

${ }^{37}$ Sáinz Jorge, "Pedro Sánchez busca inversiones el fondo soberano saudí para rescatar empresas españolas", Voz populi, 21 de febrero de 2021, en https://www.vozpopuli.com/espana/sanchez-arabia-saudi-rescatarempresas.html

${ }^{38}$ Entre otras, cabe destacar que las empresas españolas han adoptado medidas ante la acumulación de facturas impagadas y sin justificación. Al parece el Saudi Railway Organization, el grupo que contrató al consorcio español para la construcción del AVE llevar varios años sin abonar los trabajos realizados, en concreto, las certificaciones impagadas ascienden a unos 75 millones de euros solo de las facturas ya vencidas. Véase Morán, Carlos. "El AVE a la Meca: las claves del nuevo conflicto de Arabia Saudî”, Expansión, 18 de febrero de 2020 en https://www.expansion.com/empresas/transporte/2020/02/18/5e4afde9468aebad7c8b45c7.html

39 "La Supercopa se jugará en Arabia Saudí los próximos tres años a cambio de 40 millones por temporada", $L a$ Vanguardia, 11 de noviembre de 2019, en

https://www.lavanguardia.com/deportes/futbol/20191111/471524510810/supercopa-espanaarabiasaudi-trestemporadas-40-millones.html
} 
concurso de la firma pública saudí Saline Water Conversion Corporation (SWCC) para el diseño y construcción de una nueva desaladora, valorado en 384 millones de dólares. Con esta última adjudicación, Acciona realizará la quinta instalación de esta característica en Arabia Saudí y la tercera encargada por $\mathrm{SWCC}^{40}$.

Existen, en cambio, algunas debilidades políticas del régimen saudí que no se cubren con petrodólares. No nos referimos solo al "juego de tronos" por el liderazgo nacional que se ve regularmente amenazado con la compleja sucesión en la dinastía Al Saud, sino - sobre todo - a las contradicciones internas de su política exterior que limitan su atractivo en la región y coartan considerablemente su diplomacia y fiabilidad internacional. Un ejemplo sorprendente, inédito pero real ocurrió en 2013, cuando Arabia Saudí se negó a pronunciar su discurso en la Asamblea General de la Organización de las Naciones Unidas poco después de su rechazo a formar parte del Consejo de Seguridad de la ONU, como miembro no permanente, a pesar de que ya había sido elegido como tal ${ }^{41}$. Por supuesto que, en términos de principio, Arabia Saudita reafirma su compromiso con las Naciones Unidas y sus distintos organismos, pero rechazó su nombramiento en el Consejo de Seguridad alegando su doble rasero que impide - a su juicio el correcto desempeño de su responsabilidad primordial del mantenimiento de la paz y seguridad internacionales, así como su incapacidad de introducir reformas que le permitan recuperar su misión originaria ${ }^{42}$. Juno a su velada crítica al derecho de veto de los miembros permanentes del Consejo, Abdalah Y. Al-Mouallimi, el Representante Permanente de la Arabia Saudita ante las Naciones Unidas señalaba específicamente la triple incapacidad del Consejo de Seguridad para solucionar: i) la cuestión palestina; ii) para evitar que Oriente Medio sea una zona libre de todas las armas de destrucción en masa, ya que el Consejo no se había atrevido a someter de forma obligatoria a todos los programas nucleares de todos los países de la región, sin excepción, al control y la inspección internacionales; y iii) su incapacidad para evitar que cualquier país de la región posea armas nucleares. Igualmente señalaba que la falta de sanciones disuasorias contra el régimen de Damasco por el uso de armas químicas, más allá de su Resolución 2118 (2013), es una clara demostración irrefutable de la incapacidad del Consejo de Seguridad para desempeñar sus funciones y responsabilidades. Esta triple acusación sobre "la incapacidad onusiana", permite al Reino de Arabia Saudía instar a una nueva reforma del Consejo de Seguridad, y ya no solo en nombre propio sino como "responsable histórico respecto de las naciones árabes e islámicas" ${ }^{43}$. Esta actitud pro reforma choca con la pasividad mantenida

\footnotetext{
${ }^{40}$ Con esta nueva desaladora se pretende atender la carencia de agua potable en el suroeste de Arabia, de tal forma que cuando la nueva desaladora Shuqaiq 1 entre en servicio, Acciona habrá suministrado infraestructuras para el suministro diario de 1,8 millones de metros cúbicos de agua desalada mediante ósmosis inversa en Arabia Saudí. Entre los proyectos de Acciona en Arabia Saudí figura también un contrato de 530 millones para el diseño, construcción, operación y mantenimiento durante 25 años de la desaladora Shuqaiq3, que todavía está en construcción y se prevé que finalice a lo largo del 2021. Para entonces aportará 450.000 metros cúbicos diarios de capacidad (equivalente al consumo de una población de dos millones de personas). Otras de sus adjudicaciones recientes ha sido la de la desaladora Al Khobar RO2, en Khobar, en la costa este del país. Este contrato llave en mano está valorado en 460 millones de euros para una instalación que superará los 630.000 metros cúbicos diarios de capacidad. Antes, en julio de 2018, ganó el contrato para ejecutar la desaladora Al Khobar RO1, de 210.000 metros cúbicos diarios y cercana a Al Khobar RO2, por un importe de 200 millones. Y la compañía española ha diseñado y construido la planta de desalinización de agua de mar Al Jubail RO4 para Marafiq, de 100.000 metros cúbicos diarios, que sirve tanto a la ciudad como al complejo industrial anexo, al este del país.

${ }^{41}$ Carta de fecha 12 de noviembre de 2013 dirigida al Secretario General por el representante permanente de la Arabia Saudita ante las Naciones Unidas, A/ 68/599, de 14 de noviembre de 2013 en la que se recoge la Declaración del Ministerio de Relaciones Exteriores relativa a las disculpas de la Arabia Saudita por no aceptar el nombramiento como miembro del Consejo de Seguridad.

${ }^{42}$ Anexo de la carta de fecha 12 de noviembre de 2013 dirigida al Secretario General por el representante permanente de Arabia Saudita ante las Naciones Unidas Declaración del Ministerio de Relaciones Exteriores relativa a las disculpas de la Arabia Saudita por no aceptar el nombramiento como miembro del Consejo de Seguridad, A/ 68/599, de 14 de noviembre de 2013.
}

${ }^{43}$ Ibid., p. 3 
en 2005, cuando todo parecía apuntar que realmente se reformaría el Consejo de Seguridad a la luz de las variadas iniciativas presentadas en aquel momento al entones Secretario General Koffi Annan, - los denominados modelo A, modelo B, el modelo Azul o el modelo Verde ${ }^{44}$ y que fueron analizadas y debatidas en profundidad, aunque Arabia Saudí no suscribió ninguno de aquellos modelos, ni participó en el denominado "Group of Like-Minded Countries", cuya propuesta "United for Consensos" sí que fue avalada por Catar, Marruecos, Emiratos Árabes Unidos, y el representante de la Liga Árabe, entre otros.

Tras el rechazo a entrar a formar parte del Consejo de Seguridad como miembro no permanente, Arabia Saudí se presentó en 2016 como candidato al Consejo de Derechos Humanos de las Naciones Unidas por el grupo de Asia y el Pacífico, para intenta cubrir, junto con otros cinco, entre ellos China, las cuatro plazas vacantes del citado Consejo. Las críticas a Riad y Beijing no tardaron en llegar, en particular, desde reconocidas instancias de defensa de los derechos humanos, en particular desde Human Rights Wacht por las violaciones sistemáticas de los derechos humanos en ambos países ${ }^{45}$. Sin embargo, sólo Arabia Saudita se quedó fuera del reparto de sillones, mientras que Bolivia, China, Costa de Marfil, Cuba, Francia, Gabón, Malawi, México, Nepal, Pakistán, Rusia, Senegal, Ucrania, Uzbekistán y el Reino Unido entraron finalmente en el citado Consejo en enero de 2021. Ahora bien, el hecho de que solo Arabia Saudí se quedara fuera del puesto del Consejo de Derechos Humanos responde a un problema sistémico de reparto de asientos dentro del Consejo, que ya había sido elegido en 2016 por 152 votos a favor para dicho Consejo para el periodo 2017 a $2019^{46}$. Sin embargo, el rechazo de enero de 2021 es un fuerte varapalo para la nueva geopolítica saudí del príncipe heredero, Mohamed bin Salmán, que, en la votación del 13 de octubre de 2020, solo obtuvo 90 votos a favor, lo que supone una caída del $40 \%$ de su apoyo anterior por parte de las otras naciones.

\subsection{El controvertido papel del príncipe heredero Mohamed bin Salmán y la diversificación de la geopolítica}

El binomio "monarca y wahabismo" sigue vigente en el reino saudita que se ejerce adaptado a las nuevas circunstancias geopolíticas de la región y de una forma más estricta - si cabe - como consecuencia de las transformaciones de las primaveras árabes en otros países árabes vecinos, como en Egipto, Libia, Marruecos, incluso Sudan o Yemen ${ }^{47}$ y ante el auge del yihadismo radical de Al Queda y el Dáesh, especialmente, que obliga a las monarquías árabes a buscar

\footnotetext{
${ }^{44}$ Para mayor detalle, acerca de la reforma institucional del Consejo de Seguridad, Bermejo García, Romualdo; López-Jacoiste Diaz, Eugenia: "La reforma institucional de Naciones Unidas", UNISCI Discussion Papers, nº 10 (January/enero 2006), en http://www.unisci.es/la-reforma-institucional-de-las-naciones-unidas/

45 "Arabia Saudita queda fuera del Consejo de Derechos Humanos de la ONU", 14 de marzo de 2020, en https://www.france24.com/es/20201014-arabia-saudita-onu-ddhh-china

${ }^{46}$ Para aquella ocasión el régimen saudí se había preparado secundado las sugerencias de Human Rights Watch de establecer en sus normas nacionales un mecanismo de supervisión para garantizar que los organismos gubernamentales dejasen de solicitar el permiso de un tutor para que las mujeres puedan trabajar, viajar, estudiar, casarse, tener acceso a la atención de la salud o a cualquier servicio público. Igualmente, había aceptado también la recomendación del Consejo de Derecho Humanos tras su examen periódico universal celebrad en febrero y junio de 2009 de aclarar los ambiguos principios de la sharia en el derecho penal, que se prestaban a interpretaciones diversas. Además, la Comisión de Derechos Humanos de Arabia Saudita, en representación del Reino en Ginebra, aceptó la recomendación de que sólo las personas mayores de 18 años deben ser juzgadas como adultas y que debería haber una moratoria sobre la pena de muerte para las personas menores de 18 años que cometieron delitos. Véase,https://www.hrw.org/es/news/2009/06/12/onu-promete-arabia-saudita-terminar-con-el-control-de-loshombres-sobre-las-mujeres

${ }^{47}$ Lynch, Marc: "Saudi Arabia's Counter-Revolution” Foreign Policy. August 10, 201; Ottaway, Marina and Muasher, Marwan: "Arab monarchies. Chance for reform, yet unmet”, Carnegie Endowment for International Peace. The Carnegie Paper. Middle East, December 2011, en

http://carnegieendowment.org/2011/12/16/arabmonarchies-chance-for-reform-yet-unmet-pub-46243
} 
nuevas fórmulas para defender su seguridad política y religiosa, así como la perdurabilidad de sus respectivas dinastías. A pesar de que ninguna monarquía árabe cayó con las revueltas, la casa Saud también se enfrente a los nuevos retos ${ }^{48}$, con soluciones radicalmente opuestas a las del Emir Tamim de Doha.

Con el fin de contrarrestar los anhelos de modernidad política que reclaman determinados sectores de la sociedad civil y hacer frente a la disidencia política que aprovecha la débil salud del rey Salmán, el príncipe heredero, Mohamed bin Salmán ha asumido grandes responsabilidades políticas más allá de su cargo de vicepresidente primero del Consejo de Ministros. El joven Príncipe de 35 años ejerce con mano dura su misión y está adquirido un notable protagonismo controvertido como gestor de facto dentro y fuera del Reino ${ }^{49}$. Su poder casi absoluto está introduciendo cambios políticos y económicos para preservar los tradicionales intereses de la casa Saud - señalados anteriormente - aunque esto suponga la puesta en práctica de medidas drásticas, por una parte, y otras más innovadoras y futuristas, por otra $^{50}$.

Entre las medidas políticas más drásticas destacan sobre todo aquellas que tienen por objeto preservar la estabilidad interna del Reino frente a cualquier factor de tensión e imponer y garantizar una inquebrantable lealtad al monarca. En consecuencia - y como parte esencial de dicho objetivo - el príncipe heredero, Mohamed bin Salmán, se garantiza igualmente su futura corona, puesto que recordemos que él no era el príncipe heredero original de su padre. Para preservar esta estabilidad desarrolló lo que podríamos llamar una política de "oposición y disidencia 0", ya que no ha dudado en ordenar el arresto o eliminación de cualquier disidente incómodo dentro o fuera de sus fronteras e incluso, cuando se ha visto necesario, también en el seno la gran familia real. De hecho, las Leyes Básicas de 1992 y su ley antiterrorista criminaliza, entre otras cosas, "llamar al pensamiento ateo en cualquier forma o cuestionar los fundamentos de la religión islámica" y criminaliza a "cualquiera que desafíe, directa o indirectamente, la religión o la justicia del Rey o Príncipe heredero". A partir de 2018, un año después de su nombramiento como Príncipe heredero, algunos disidentes políticos, ex espías saudíes ${ }^{51}$ o defensores de los derechos humanos han desaparecido ${ }^{52}$, se han visto obligados a emigrar o han sido juzgados por tribunales antiterroristas. Pero sin duda, el caso más mediático fue el asesinato del columnista del Washington Post Yamal Khashoggi en el Consulado en Estambul el 2 de octubre del 2018, a pesar de que era un crítico moderado contra el Gobierno saudí. Según se desprende de ciertos documentos de la CIA, descalificados por órdenes de Joe Biden, Mohamed bin Salmán podría estar directamente involucrado. Según el informe de la Oficina de la Directora de Inteligencia Nacional de Estados Unidos $^{53}$, todo apunta a que el príncipe heredero Mohamed bin Salman

\footnotetext{
${ }^{48}$ Yom, Sean L.and Gause, Gregory: "Resilient royals: how Arab monarchies hang on", Journal of Democracy, October 2012, vol. 23, nº 4, pp. 74-88.

${ }^{49}$ Legrenzi Matteo: “La Nuova Arabia Saudita: ¿isolata o protagonista?”, Vita e Pensiero, vol. 6, (2017), pp. 4752.

${ }^{50}$ En el reciente libro de Madawi Al-Rasheed: The Son King Reform and Repression in Saudi Arabia Oxford University Press 2021 se analizan y valoran las muchas reformas emprendidas por el Principe heredero tras el asesinato del periodista Jamal Khashoggi. Con acierto, el autor descarta puntos de vista un tanto obsoletos sobre el ineludible "despotismo oriental" como el único camino hacia una reforma genuina en el país.

${ }^{51}$ Como es el caso del antiguo jefe de espías saudí Saad al Yabri, exiliado en Canadá, que presentó una demanda en Washington contra el príncipe heredero, https://elpais.com/internacional/2020-08-07/un-exministro-saudiacusa-al-principe-heredero-de-intentar-asesinarlo-en-canada.htm

52 Como fue el caso de Loujain al Hathoul, que fue encarcelada en mayo de 2028, https://www.amnesty.org/es/latest/news/2021/03/saudi-arabia-verdict-upholding-loujain-al-hathlouls-convictionan-appalling-injustice/

${ }^{53}$ Navarro, Beatriz: "La CIA acusa al príncipe heredero saudí de "ordenar" el asesinato de Khashoggi", La Vanguardia, 27 de febrero de 2021, en

https://www.lavanguardia.com/internacional/20210226/6260394/cia-arabia-saudi-principe-khashoggidisidente.html
} 
aprobó la operación para "capturar o matar" a Yamal Khashoggi, ya que, desde 2017 el príncipe heredero ejercía un control absoluto de las organizaciones de seguridad y los servicios de inteligencia del Reino, por lo que hace altamente improbable - para la CIA - que aquellos 18 funcionarios saudíes juzgados por el asesinato de Khashoggi en el consulado de Estambul hubiesen realizado semejante "operación" de envergadura internacional sin la autorización del Príncipe. Para la CIA es inconcebible que según la forma de Gobierno autoritaria de la casa Salud y - ahora del Príncipe Mohamed bin Salmán - que sea verdad la postura oficial de Riad de que los agentes actuasen por libre. Es altamente "improbable" además, según la CIA, que los agentes cuestionaran las órdenes del Príncipe por el temor (fundado) a sufrir represalias. El equipo que ejecutó a Khashoggi estaba compuesto por personas que trabajaban en Palacio para el Centro Saudí para Estudios y Asuntos de los Medios de Comunicación, entonces dirigido por Saud al Qahtani, asesor del príncipe heredero Mohamed bin Salman y el subdirector de los servicios secretos saudíes y otros miembros de la Fuerza de Intervención Rápida ${ }^{54}$.

La inquebrantable lealtad al rey impuesta por Mohamed bin Salmán está poniendo en peligro los equilibrios de consenso alcanzados dentro de la familia real, lo que está resucitando viejas rencillas y tensiones tradicionales internas. Sin ir más lejos, en 2020, el príncipe heredero ordenó arrestar al propio Mohamed bin Nayef y al príncipe Ahmed bin Abdelaziz, hermano del rey Salmán, primo y tío respectivamente del Mohamed, quien sustituyó al primero como Príncipe heredero en 2017. En marzo de 2019 la princesa Basmah bint Saúd, la más joven de los 115 hijos del rey Saúd (que gobernó entre 1953 y 1964) fue invitada a una reunión privada con su primo Mohamed bin Salmán, pero acabó detenida junto a una de sus cinco hijas. La desaparición de la princesa Basmah es similar a la del príncipe Salmán bin Abdulaziz, otro primo del príncipe heredero que fue detenido en 2018 y aunque todavía no se han presentado cargos contra ellos, ambos siguen en paradero desconocido ${ }^{55}$. El 4 enero de 2018, la Fiscalía de Arabia Saudí anunció la detención de otros 11 príncipes que supuestamente fueron al palacio real para protestar por una nueva reforma impulsada por el Príncipe heredero, que les obligaba a pagar las facturas de luz y agua de sus palacios y exigieron una indemnización por la condena a muerte de uno de sus primos, el príncipe Turki bin Saud al Kabir, primer miembro de la familia real condenado a muerte en más de 40 años. Según la Fiscalía, todos ellos son responsables de perturbar la paz y orden público, según las Leyes Básicas de 1992.

La mano dura contra los disidentes políticos o contra quienes refutan los planes políticos del monarca o su príncipe heredero, también se observan, por ejemplo, en sus relaciones con el Líbano. De una forma un tanto rocambolesca, Mohamed bin Salmán fue responsable de retener durante varios días, en noviembre de 2017, al primer ministro libanés Saad Hariri, con el objetivo de mostrar su desacuerdo con el Gobierno libanés por no controlar al Herzbollah. La explicación pública ofrecida por las autoridades apuntaba a que Hariri - que tiene la doble nacionalidad libanesa y saudí - había presentado su dimisión estando en Arabia, pero el

\footnotetext{
${ }^{54}$ Como se sabe, el escándelo fue tal, que la justicia saudí dictó sentencia condenatoria dos años más tarde, contra la que no cabe apelación alguna. Según la fiscalía general ocho de los autores encantados responsables fueron castigado con 124 años de cárcel; otros cinco responsables fueron condenados a muerte, pero en septiembre de 2020, se les conmuto dicha pena por 20 años de prisión por petición expresa de los hijos de Khashoggi, que no por la autoridad judicial saudí. Los hijos anunciaron el perdón a los asesinos coincidiendo con el mes del Ramadán, tal y como lo permite la ley islámica por lo que se puede suspender la ejecución de la sentencia de muerte y conmutarla por otra pena. Por último, los tres encubridores deberán cumplir entre 10 y 7 años de prisión. Véase Espinosa, Ángeles, “Arabia Saudí conmuta la pena de muerte a los condenados por el asesinato de Khashoggi”, El País, 7 de septiembre de 2020, en https://elpais.com/internacional/2020-09-07/arabia-saudi-conmuta-la-penaa-muerte-a-los-condenados-por-el-asesinato-de-khashoggi.html.

${ }^{55}$ Sobre estos hechos, Biosca Aizcoiti, Javier: "La princesa y el príncipe desaparecidos de Arabia Saudí: los suyos confían en el poder de Biden para su salvación”, 6 de febrero de 2021, en https://www.eldiarioar.com/mundo/principes-desaparecidos-arabia-saudi-confian-biden-

liberacion_1_7200951.htm
} 
escándalo que tal planteamiento provocó obligó a las autoridades saudíes a permitir su regreso a Beirut.

La particular forma de entrenar y defender la lealtad a la Corona no ayuda demasiado a un reconocimiento del Reino saudita como un socio fiable y relevante de la comunidad internacional y así se aprecia al menos desde la Subcomisión de Derechos Humanos de la Unión Europea que emplaza al Consejo de Derecho Humanos a crear un Grupo especial de trabajo y de investigación por la represión de los defensores de los derechos humanos, activistas y críticos del régimen del príncipe heredero por ordenar las detenciones arbitrarias o por haber sido condenados injustamente a largas penas de prisión por el mero hecho de ejercer su derecho a la libertad de expresión. La citada Subcomisión exhorta al Parlamento Europeo que solicita formalmente que se "condene enérgicamente la detención de las defensoras de los derechos humanos y pide a las autoridades saudíes que pongan en libertad, inmediata e incondicionalmente, a estos los defensores de los derechos humanos, abogados, periodistas y otros presos de conciencia privados de libertad y condenados únicamente por ejercer su derecho a la libertad de expresión y por su labor pacífica en favor de los derechos humanos, y que permitan a observadores internacionales independientes reunirse con los defensores de los derechos humanos privados de libertad" ${ }^{\text {" }}$. Por el momento, la UE guarda silencia y todavía no se ha aprobado ninguna nueva Decisión PESC al respecto, ni se ha fijado una posición unificada para garantizar que los servicios diplomáticos europeos en Arabia Saudí utilicen sistemáticamente los mecanismos previstos en las Directrices de la UE sobre defensores de los derechos humanos, incluidas declaraciones públicas, gestiones diplomáticas, supervisión de juicios y visitas a prisiones, en relación con los defensores de los derechos de las mujeres saudíes detenidos desde mayo de 2018. Quizás para evitar ser tachado de "cómplice por omisión" la UE considera que la ONU ya cuenta con un grupo trabajo sobe detención $\operatorname{arbitraria}^{57}$, que, si bien no se ciñe exclusivamente a lo acontecido últimamente en Arabia Saudí, sirve igualmente para ese fin ${ }^{58}$.

El nacionalismo populista impuesto por Bin Salmán y que divide a la sociedad saudí junto con la represión de las diversas voces críticas de eruditos religiosos, feministas y profesionales, no ha logrado silenciar a una vibrante sociedad saudita joven y a una cohorte juvenil articulada y conectada. Sin embargo, la mano dura del Príncipe está produciendo numerosas solicitudes de asilo y de refugiados que buscan refugios seguros en el extranjero para perseguir su libertad, igualdad y dignidad, a pesar de que el régimen continúa persiguiéndolos en el extranjero y castigando a sus familias en casa ${ }^{59}$. Este tipo de políticas estrictas y de represalias explican la deteriorada reputación internacional de Arabia Saudí, cuando se presentó a la renovación de su puesto en el Consejo de Derechos Humanos y así quedó reflejado en aquella votación. Pero las reivindicaciones de reformas democráticas para Arabia Saudita no solo provienen de las instancias internacionales ${ }^{60}$, sino también de

\footnotetext{
${ }^{56}$ Resolución del Parlamento Europeo de 14 de febrero de 2019, sobre los defensores de los derechos de las mujeres en Arabia Saudí (2019/2564(RSP)) (2020/C 449/17).

${ }^{57}$ La resolución 42/22, de 26 de septiembre de 2019 del Consejo de Derechos Humanos prorrogó recientemente el mandato del Grupo de Trabajo por un periodo de tres años.

${ }^{58}$ Hakala, Pekka (2013): "Cautions reform in Saudi Arabia", Directorate General for Internal Policies, European Parliament, p. 4.

${ }^{59}$ Véase, Al-Rasheed, Madawi (2021): The Son King Reform and Repression in Saudi Arabia, Oxford University Press.

${ }^{60}$ Durante el examen periódico a Arabia Saudí en el Consejo de los Derechos Humanos, los Estados que quisieron presentaron sus preguntas de reformas al especial al representante saudí. Por ejemplo, España planeó las siguientes: Ya que Arabia Saudí rechazó en el pasado examen periódico la recomendación de introducir una moratoria en la aplicación de la pena de muerte, ¿piensa reducir su ámbito de aplicación? ¿limitar los delitos sujetos a pena capital, limitándolos a los delitos más graves, entre los que no cabría incluir la apostasía o el tráfico de drogas? ¿Proyecta el Gobierno de Arabia Saudí sistematizar la recogida de datos y estadísticas sobre la violencia contra la mujer,
} 
determinados sectores saudíes, como Leah Whitson, directora de Democracy for the Arab World Now, que es la organización fundada por el periodista saudita Yamal Khashoggi, asesinado por agentes saudíes en el consulado de su país en Estambul en octubre de 2018.

Como se ha visto en el apartado anterior, el Príncipe heredero también ha adoptado una política económica renovada y drástica. Los ataques a Aramco de 2019 y la bajada del precio del crudo puso en evidencia la excesiva dependencia saudí del petróleo ${ }^{61}$. Para garantizar la estabilidad interna y facilitar la consecución de objetivos saudíes regionales ${ }^{62}$, Mohamed bin Salmán, como presidente del Consejo de Economía y Asuntos de Desarrollo ha diseñado un plan para una mayor diversificación de su economía a medio plazo, aprobado bajo el nombre Visión $2030^{63}$. Ente muchas otras cuestiones, este plan contempla privatizaciones, incluida la de la empresa Aramco, y el aumento del número de licencias concedidas a compañías extranjeras, principalmente rusas, chinas, españolas y francesas, para la exploración conjunta de nuevos yacimientos y la construcción de más instalaciones ${ }^{64}$. Además, se propone el desarrollo de sectores no dependientes del crudo, como la minería y el turismo, así como la modernización de los fines fundacionales del PIF y una nueva política de expansión de las inversiones saudíes más allá del mundo árabe - aunque sin olvidar el desarrollo nacional llegando hasta el corazón del capitalismo occidental. Sus aspiraciones se ven, no obstante, truncadas parcialmente por la falta de recursos y ha debido elegir: sus proyectos de desarrollo o las causas árabes y musulmanes. Apostando por las primeras, ha tenido que recortar la financiación a causas árabes y musulmana, como la ayuda a los palestinos, a Pakistán y tampoco ha logrado apuntalar al Líbano, además, de reducir drásticamente los proyectos de construcción de mezquitas para la difusión del conservadurismo religioso del Reino por todo el mundo.

Las ambiciones del Príncipe heredero Mohamed bin Salmán están promoviendo también el desarrollo y modernización nacional, como elemento clave para preservar la casa Saud y la hegemonía del Reino en la región el en contexto de su plan Visión 2030. Sus proyectos futuristas resultan cuanto menos llamativos y paradójicos en un país donde el binomio "Estado y wahabismo" ha forjado una sociedad altamente conservadora donde la religión juega un papel central en la elaboración del discurso político tanto para gobernantes como para oponentes y es una potente herramienta de legitimación. A pesar de que ya se han emprendido ciertas reformas y restricciones al poder de los clérigos wahabíes, y se han introducido cambios importantes en la condición de la mujer, las aspiraciones de nuevos proyectos de modernización "a la Occidental" sorprenden a los estamentos religiosos más puritanos del islam cuya influencia política y social no se debe subestimar. Su apoyo o sus objeciones pueden alentar a los islamistas progresistas, nacionalistas y chiítas a presionar por un cambio hacia una alternativa

\footnotetext{
desglosados por tipo de violencia y relación con el agresor? ¿Proyecta el gobierno de Arabia Saudí profundizar en las reformas para lograr la igualdad legal y efectiva de hombres y mujeres, eliminando el sistema de tutela masculina? ¿Entra dentro de los planes del Gobierno saudí la supresión de la figura del sponsor sobre los trabajadores extranjeros? Véase, el Informe: Advance Questions to Saudi Arabia-Add2: Spain, en https://lib.ohchr.org/HRBodies/UPR/Documents/Session17/SA/SaudiArabiaAdd.2_UPR17.docx

${ }^{61}$ Even, Shamuel and Guzansky, Yoel: "Saudi Arabia's Vision 2030: Reducing the Dependency on Oil" The Institute for National Security Studies, INSS Insight, $\mathrm{n}^{\mathrm{o}} 819$, 6 May 2016, en: http://www.inss.org.il/publication/saudi-arabias-vision-2030-reducingthe-dependency-on-oil/

${ }^{62}$ Para un mayor detalle sobre estas cuestiones, Hernández Martínez, David. (2020): El reino de Arabia Saudí, op. cit., pp. 100-108.

${ }^{63}$ Ibid., p. 55. Como señala Hernández Martínez el plan Saudi Vision 2030 (o Visión 2030 en español) aprobado el 24 de abril de 2016, realiza un análisis general de las fortalezas y debilidades del Reino, así como los fines a conseguir a medio plazo para consolidarse como potencia económica mundial.

${ }^{64}$ Taher, Abdulhadi Hassan (2011): Petroleum, gas and development strategies of Saudi Arabia, London, Saqi Books, pp.77-79.
} 
no violenta, centrada en el islam, local y respetuosa del papel unificador de la Casa Saud o - al contrario - podrían desempolvar amenazas del pasado desde un extremismo violento ${ }^{65}$.

Uno de los proyectos estrellas de Príncipe heredero es el denominado Proyecto mar Rojo para aprovechar mejor - hasta las últimas consecuencias - el potencial turístico del Reino. Su objetivo es transformar el archipiélago de unas 90 islas vírgenes de playas de arena blanca en un 'destino turístico de lujo exquisito' con espectaculares paisajes montañosos. Se construirán de 50 hoteles con una capacidad de 8.000 habitaciones y 1.300 propiedades residenciales, por lo que impulsará al sector de la construcción en desaceleración, pero sin perder de vista la sostenibilidad ambiental, ya que - según los simuladores desarrollas al efecto - se garantizaría un impacto positivo en la conservación animal de la zona en del 30\% y la energía será 100\% renovable, además de contrar con una política de cero residuos. Estas islas abarcan más de 200 $\mathrm{km}^{2}$ en la costa occidental del Reino, situadas entre las ciudades de Al Wajh y Umluj, a $350 \mathrm{~km}$ cerca de la costa. Será un destino turístico de lujo - equivalente a la Islas Palm de los Emiratos Árabes Unidos - y que sea competitivo frente al turismo de Egipto, Jordania. Israel o Abu Dabi, ya que, desde las nuevas instalaciones, los turistas tendrán la oportunidad de visitar las antiguas ruinas de Mada'in Saleh, clasificadas como Patrimonio de la Humanidad por la UNESCO, el primer lugar patrimonial en Arabia Saudita.

Este proyecto es otra de las formas saudíes de fomentar el desarrollo nacional y local a muy diversos niveles y sectores. El turismo es la segunda fuente de ingresos más importante del Reino, por detrás de los hidrocarbonos. De tal forma que el Proyecto diversificará y explotará ámbitos del turismo poco relevante hasta la fecha. Tradicionalmente Arabia Said se había centrado en el turismo religioso que acoge a un promedio de 10 a 13 millones de peregrinos a las dos ciudades santas cada año, incluidos más de 2 millones de peregrinos que visitan para el Hajj anual. Y dentro de este plan de diversificación y de posición relevante en el mundo musulmán, los saudíes también se proponen "aumentar su capacidad para recibir visitantes de la Umrah de 8 millones a 30 millones cada año para 2030". En cambio, el nuevo turismo de lujo atraerá a los turistas extranjeros, que según la nacionalidad pueden no requerir visado alguno, mientras otros podrían obtener visas on line y /o otras facilidades antes de su llegada. Además, se espera que promueva el turismo interno, reduciendo el número de saudíes que salgan de vacaciones del Reino. En la estrategia de promoción del proyecto Mar Rojo ya se anuncia que el nuevo archipiélago será un territorio regido por leyes propias, gozará de un cierto grado de autonomía y que el Gobierno adoptará "leyes internacionales estándar", según ha transmitido la Agencia de Prensa Saudita (SPA) ${ }^{66}$.

El Proyecto mar Rojo creará - según fuentes oficiales - nuevos puestos de trabajo y empresas nacionales de servicios, sin perjudico de la deseada "asociación con empresas mundiales de primer nivel" con el fin de "atraer inversiones nacionales, árabes, del Golfo e internacionales" al Reino. Quizás también esté detrás la idea de frenar expansión por la Península Arábiga de cadenas hoteleras y de catering extranjeras, en particular, las de la Indica, como la Taj International Limited, Oberoi, ITC, o Hotel Leela, entre otras ${ }^{67}$. El ministro de Comercio e Inversiones, Majid Al-Qassabi, dijo que el Proyecto brindará grandes "oportunidades de inversión y abrirá el camino para asociaciones con las principales empresas

\footnotetext{
${ }^{65}$ ICG Middle East: “Can Saudi Arabia Reform Itself?”, Report n 28, 2014 en

https://www.crisisgroup.org/middle-east-north-africa/gulf-and-arabian-peninsula/saudi-arabia/can-saudi-arabiareform-itself

66 Al Yousif, Mohammed and Al Bakr, Ahmed: "Tourism Development Effect on Saudi Economic Diversification", SAMA Working Paper, March 2017, en https://islamicmarkets.com/publications/tourismdevelopment-effect-on-saudi-economic-diversification

${ }^{67}$ Hussain, Zakir: "Saudi Arabia's Red Sea Project: Harnessing Tourism for Diversifications", Indian Council of World Affairs, (August 2017), pp. 1-11, p. 6.
} 
del mundo en el sector turístico, impulsando la economía nacional de acuerdo con la Visión $203{ }^{\prime \prime 68}$. El Proyecto Mar Rojo será financiado por el PIF soberano, en su primera fase, pero se espera que pueda duplicar su crecimiento y aumentar los ingresos en un $18 \%$ en los próximos 14 años, hasta poder generar 1,2 millones de puestos de trabajo para los saudíes para 2030. Un estudio realizado por Yousif y Al Bakr, asociado con la Autoridad Monetaria de Arabia Saudita (SAMA), estimó que una inversión de 1 millón de SAR en el sector turístico genera en promedio 1,4 nuevos puestos de trabajo en el Reino.

Otra gran apuesta del Príncipe heredero para transformar Arabia Saudí en una económica diversificada es Neom, un futuro centro neurálgico de comercio, tecnología y biomedicina puntera. Su nombre provine de una mezcla entre neo, la palabra griega para "nuevo" y el comienzo de Mostaqbal, término árabe que significa "futuro", y tendrá una superficie tan grande como Bélgica. Neom será una ciudad-estado que operará de manera independiente del Gobierno saudí; tendrá sus propias leyes laborales, un marco fiscal diseñado específicamente para ella y un sistema judicial completamente autónomo. Su desarrollo incluye la construcción de un puente sobre el Mar Rojo que conectará ese rincón de Arabia Saudita, con una extensión de más de $26,000 \mathrm{~km}^{2}$ de arena, rocas y costa desierta con Egipto. La decisión de ubicar Neom en esta área no es casual; se debe a que el 10\% del comercio global pasa a través del Mar Rojo y se estima que el $70 \%$ de la población mundial tiene acceso a esta zona en menos de 8 horas. Según los medios de comunicación ${ }^{69}$, el sueño del príncipe Mohamed bin Salmán es crear un lugar donde la tecnología, el entretenimiento y el turismo se olviden de Silicon Valley, Hollywood y las playas caribeñas. En principio se planea inaugurar la primera fase de Neom en 2025, pero no se podrá disponer de una flota de taxis voladores hasta $2030^{70}$.

Con estos dos grandes proyectos futuristas, Mohamed bin Salmán aspira a una "Arabia Saudí fuerte, próspera y estable que ofrezca oportunidades a todos", y a que la sociedad saudí sea una "sociedad vibrante", que es el uno de los tres pilares de la Visión 2030. Pero su plan no contempla el frenazo actual de su económica y la imprevisibilidad está disuadiendo a los inversores extranjeros de invertir en los proyectos de su Visión 2030. Ni qué decir, acerca del gran silencio de este plan de reformas en materia de derechos humanos, ni reformas democráticas que haría más fiable su potencial económico mundial y lograrían un Reino con igualdad de oportunidades y estabilidad política más allá de la región.

\section{La política exterior saudí: desde alianzas de conveniencia y enemistades históricas, hasta nuevas y sorprendentes relaciones de buena vecindad}

En política exterior, el rey Salmán y el príncipe heredero Mohamed bin Salmán se han visto obligados en enmendar la estrategia seguida por el anterior soberano, Abdalá bin Abdulaziz, que tuvo que hacer frente en los últimos años de su reinado a la primavera árabe y a los efectos directos de tales rebeliones, rompiendo, por lo tanto, con tu tradicional postura más observadora y discreta, que activa y llamativa ${ }^{71}$. El actual monarca - impulsado por su hijo - decidió desarrollar una nueva política exterior autónoma, en la que ni sus objetivos ni los instrumentos están subordinados a la política exterior de ningún Estado, algo que hasta ahora había sido la

\footnotetext{
${ }^{68}$ Ibid., p. 3

${ }^{69}$ El-Erian, Mohamed A.: "Saudi Arabia's attempt to reduce reliance on oil has the world rapt", The Guardian, 16 May 2016, en https://www.theguardian.com/business/2016/may/16/saudi-arabia-reduce-reliance-oil-vision-2030. 70 "Neom: la ciudad futurista del Príncipe Heredero saudî", diciembre de 2017 https://www.gualestrit.com/neomla-ciudad-futurista-del-principe-heredero-saudi/

${ }^{71}$ Poza Cano, David: 'El derrumbe del 'statu quo' en Oriente Próximo: las estrategias de seguridad de Irán y Arabia Saudî”, Instituto Español de Estudios Estratégicos, Documento de Opinión n¹0 (2017), p.7 en http://www.ieee.es/Galerias/fichero/docs_opinion/2017/DIEEEO10-2017_OrienteProximo_DavidPoza.pdf
} 
nota dominante ${ }^{72}$. El nuevo enfoque Salmán busca adaptar sus propias estrategias y objetivos de desarrollo nacionales e internacionales al nuevo escenario convulso e impredecible de Oriente Medio. Su Visión 2030 se rige por la necesidad de que Arabia Saudí mantenga un papel significativo y contrarreste la fuerza de otros movimientos propiciados por actores regionales, internacionales y no estatales ${ }^{73}$. El diseño de su política exterior se construye sobre la base de tres esferas: la primera versa sobre la misión de la monarquía en Arabia Saudí, en Oriente Medio y en la esfera musulmana; la segunda en el análisis elaborado sobre los acontecimientos ocurridos en los últimos tiempos que han erosionado los márgenes de seguridad; y tercero, la obligación de hacer frente a las futuras amenazas, riesgos y oportunidades que se suscitan como consecuencia de los complejos escenarios y crisis del pasado. La estrategia se enfoca espacialmente en aquellos escenarios considerados primordiales para el equilibrio y seguridad de los Saud entre las distintas corrientes ${ }^{74}$, como pueden ser la guerra en Siria y Yemen, la situación en Irak o las tensiones con Catar. Cada uno de estos epicentros representa un posible foco de amenaza para la hegemonía saudita, pero también una nueva oportunidad para ganar la pugna por el liderazgo político en la región que, por el momento, tiene carácter multipolar y está fragmentada en función de los variados intereses en juego cambiantes en cada momento.

Desde esta perspectiva, se puede afirmar que la política exterior saudí está parcelada en cuatro grandes dimensiones: 1) la prioritaria sobre el Golfo; 2) la dimensión árabe o regional; 3) el mundo Islámico y 4) la sociedad internacional ${ }^{75}$. Y, en todas ellas, Riad tiene una clara prioridad: reestablecer las líneas rojas y alianzas que sean necesarias para poder restringir al máximo posible la fuerza iraní. Primero, haciéndole frente en el Golfo con el resto de monarquías árabes. Segundo, recuperando en la esfera musulmana la distinción sectaria clara entre Estados árabes y sunnitas y naciones no sunnitas dentro del entorno de Oriente Medio. Tercero, volviendo a implantar un cordón sanitario sobre Irán a escala internacional, contando con la connivencia de los Estados Unidos y otras potencias extranjeras. La principal inspiración de esta política exterior es la base religiosa del propio Estado saudí: el wahabismo sigue brindando cobertura religiosa a la dinastía Al Saud quien favorece y defiende esta visión religiosa por todo el mundo. Pues, con palabras de Gil Pérez, Arabia Saudí es uno de los "grandes faros iluminadores del islamismo en la actualidad"76, junto con Catar, Turquía, Emiratos Árabes Unidos, Kuwait e Irán, tanto por su peso estratégico, como económico o ideológico-religioso.

Ahora bien, para llevar a término estos propósitos, para la Corona saudita, es más rentable tratar de cerrar algunos frentes y no abrir nuevos focos de tensión con Estados más alejados de sus habituales relaciones regionales, con el fin de no arriesgar sus lazos comerciales,

\footnotetext{
72 Priego Moreno, Alberto: "La nueva política exterior de Arabia Saudî", Instituto Español de Estudios Estratégicos, Documento marco 18/2015, pp.1-20, p. 5, en http://www.ieee.es/Galerias/fichero/docs_marco/2015/DIEEEM182015_NuevaPoliticaExterior_ArabiaSaudi_A.Priego.pdf 73 "Vision 2030, laying the foundations for our future", en https://www.vision2030.gov.sa/

${ }^{74}$ Gardner, Frank. "Saudi Arabia's king Salman marks year of change" BBC News, 22 enero 2016, en https:// www.bbc.com/news/world-middle-east-35370801

75 Sobe estas zonas o prioridades, Al-Ghamdi, Saleh bin Mohammed: "Saudi Foreign Policy-The policy of principles" en The Saudi non-resident Ambassador to Bulgaria delivers a lecture at the Diplomatic Institute of Sofia. Diplomatic Institute of the Ministry of Foreign Affairs of Bulgaria, 30 March 2011, en https://www.mofa.gov.sa/sites/mofaen/KingdomForeignPolicy/Pages/ForeignPolicy24605.aspx.Vease igualmente las acertadas observations y análisis de la parte III del libro editado por Al-Rasheed, Madawi: Salman's Legacy The Dilemmas of a New Era in Saudi Arabia, Oxford, Oxford University Press, 2018.

${ }^{76}$ Son las palabras textuales del Gil Pérez, Javier: "Análisis de las políticas exteriores de los grandes faros iluminadores del islamismo en la actualidad: Arabia Saudí, Catar, Turquía, Emiratos Árabes Unidos, Kuwait e Irán”, en Carlos Echeverría (coord.) (2018): Democracia e Islam, ¿una relación imposible? Comares, Granada, pp. 14-23.
} 
tan necesarios para el reflote de su estancada economía y para la efectividad de su Visión 2030. En consecuencia, en este momento la prioridad saudí es terminar su guerra en Yemen debido a la intensidad, el alcance geográfico y la naturaleza de los objetivos que atacan los hutíes en su territorio ${ }^{77}$. La segunda prioridad en términos de política regional, que también está vinculada a Yemen, es Irán que siempre ha sido percibido como una gran amenaza, debido a su capacidad para amenazar la seguridad nacional y la estabilidad del régimen de Arabia Saudita. Además, la vasta red de aliados regionales no estatales de Teherán está dañando los intereses estratégicos de Arabia Saudita en todo el Oriente Medio, especialmente en el área del Golfo. De momento Arabia Saudí percibe la administración de Biden como una continuación de la administración de Obama en términos de cómo tratar con Irán, es decir, a través de negociaciones y contención en lugar de confrontación. De ahí que a la Corona saudí le preocupe las consecuencias del affaire Khashoggi, y no solo en la esfera comercial, sino las diplomáticas con Turquía, que forma parte del llamado triunvirato, junto con Rusia e Irán, y que comparten intereses diplomáticos en el marco de Astaná y Sochi y otros sobre el terreno, cuestión que sin duda irrita a Riad. Y, por otra, la política exterior de la Corona Saud debe ser cauta para mantener, ampliar y diversificar su red de alianzas estratégicas con terceros Estados, tanto bilaterales como multilaterales para garantizarse su propia seguridad en su zona de influencia y evitar la injerencia iraní, al mismo tiempo, que persigue resultados económicos y políticos rentables que hagan al Reino saudí un socio oportuno e imprescindible. El rey Salmán es plenamente consiste de esta realidad, y a pesar de su avanzada edad, dio un primer paso importante con su visita a Moscú en 2017 para recomponer sus rotas relaciones tras varios años de hostilidades, mientras que para Rusia aquella visita suponía como oportunidad más de incrementar su presencia en Oriente Medio para hacer valer su peso decisorio en la oferta petrolífera.

\subsection{Alianza de conveniencia y desconfianza mutua: principales actos y escenas de las relaciones entre Arabia Saudí y los Estados Unidos}

El "matrimonio de conveniencia" entre los Estados Unidos y Arabia Saudí data de 1945, cuando Franklin Roosevelt conoció al monarca saudita Abdulaziz a bordo de un crucero estadounidense. Ambos se percataron de que se necesitaban mutuamente por motivos distintos, aunque algunos comunes que prevalecen hasta nuestros días en el convulso escenario internacional y que son coincidentes en cuanto al beneficio obtenido por cada una de las partes de esta paradójica alianza bilateral. La complicidad y el recelo recíproco varían en función de los acontecimientos y del relevo histórico de los principales actores implicados: los diversos monarcas saudíes, por una parte, y las políticas republicanas o demócratas, por otra. La Corona saudí fue uno de los interlocutores más fiables de los Estados Unidos en Oriente Medio, mientras que Washington apoyaba internacionalmente a la dinastía Al Saud dentro del mundo musulmán. Como señala David Hernández, sin ese respaldo tácito de la Casa Blanca, la supervivencia de los Al Saud en el trono y su posición de liderazgo en la región y en la esfera musulmana hubiera sido menos probable ${ }^{78}$. Su alianza podría denominarse como un programa de intercambio de "petróleo por seguridad militar", tomando el símil del plan de las Naciones Unidas para Irak "petróleo por alimentos", aunque con muchos altibajos, ya que en el entendimiento entre Washington y Riad se esconden principios y elementos más complejos y cambiantes según las circunstancias específicas de cada caso, tanto de carácter comercial, financiero o energético, pero sobre todo y principalmente geopolítico.

\footnotetext{
${ }^{77}$ Farouk, Yasmine, "Saudi Arabia's Foreign Policy”, 24 May 2021, en https://gjia.georgetown.edu/2021/05/24/dr-yasmine-farouk-on-saudi-arabias-foreign-policy/

${ }^{78}$ Hernández Martínez, David: "La Alianza de Estados Unidos y Arabia Saudí en el siglo XXI. La presidencia de Georg W. Bush, Barack Obama y Donald Trump”, Revista del Instituto Español de Estudios Estratégicos, $\mathrm{n}^{\circ} 15$ (2020), pp. 43-66, p. 45.
} 
La armoniosa conveniencia política inicial se manifestó - por ejemplo - en que los saudíes ejercieron con maestría un uso equilibrado y ponderado del hard y soft power durante los últimos años de la Guerra Fría, apoyando a los norteamericanos en la guerra afgana contra las tropas soviéticas. Los Estados Unidos, continuando con su estrategia de contención del bloque socialista, querían desgastar a su rival soviético, pero sin arriesgar el libre flujo de crudo por el Golfo Pérsico. En consecuencia, les resultaba más necesarias que nunca sus relaciones con Arabia Saudí, que, como país líder del credo islámico, tenía intereses en Afganistán por una doble razón: tanto para evitar que el islam fuera barrido de aquel país por el credo comunista, como para atraer hacia Afganistán la atención de los radicales internos que de ese modo no dirigían sus iras contra el poder de la familia Saud. La gran comunidad musulmana del mundo compartía con Arabia Saudí la preocupación de que "la sagrada tierra del islam" retrocediera en esa región de Asia Central. Irán, el país líder del credo chiíta, pretendía además apoyar a la minoría chiíta de Afganistán y seguía con atención todo lo que pudiera ocurrir en el país vecino.

Ante ese panorama, los saudíes no dudaron en apoyar a los muyahidines afganos en su lucha contra la Unión Soviética en Afganistán. El apoyo en Afganistán a la causa yihadista se realizó en perfecta connivencia con los Estados Unidos, ya que ambos países suministraron millones de dolores canalizados a través de Pakistán para apoyar a la insurgencia yihadista afgana contra el Gobierno comunista de Kabul y su apoyo soviético. La colaboración se concentró en la compra de armas, equipos de comunicación y formación religiosa en madrasas situadas en Pakistán. Aquellos actos no solo beneficiaron a los Estados Unidos, sino que para los saudíes supuso su primera gran incursión en política exterior contra el comunismo - tras la revolución islámica de Irán - y la defensa del islamismo más agresivo. Pocos años después, en la Guerra del Golfo del 1991 se consagró el poderío militar norteamericano, lo que alertó a los sectores más conservadores saudíes que ejercieron una fuerte oposición para que las tropas occidentes no se instalasen en su territorio ni siquiera para su defensa frente a una posible agresión de Irán o Irak.

A la vuelta de los años, las relaciones Riad-Washington en Afganistán contra la Unión Soviética pasaron su factura a los Estados Unidos con el 11-S, ya que ese radicalismo religioso plantado en Pakistán y Afganistán con la ayuda saudí tendría su continuación con el régimen talibán, hasta la actualidad. De hecho, el Emirato Islámico de Afganistán que rigió el país entre 1996 y 2001 solo fue reconocido por Pakistán, Arabia Saudí y Emiratos Árabes Unidos. Es por ello, que Echeverría resalta con razón el profundo impacto que ha tenido la propagación del wahabismo en Afganistán y en Pakistán, cuyas consecuencias siguen presentes en forma de grupos violentos en toda la región ${ }^{79}$.

A partir del 11-S comienza una etapa de desconfianza mutua a causa de la nueva era "de lucha contra el yihadismo" y los ataques terroristas a escala mundial, por lo que se pone el foco de atención en Arabia Saudí, el wahabismo y el tipo de contactos que mantiene con ciertos grupos radicales. Dicha desconfianza se acrecentó aún más si cabe, cuando los Estados Unidos invade Irak en 2003, a pesar de las objeciones de algunos funcionarios saudíes, que temían que desestabilizara aún más la región. La doctrina Bush no se limitaba exclusivamente a combatir a Al Qaeda, sino que se extendía a todas las organizaciones e instituciones que amparaban a ese tipo de actores. Arabia Saudí queda, por tanto, en una situación muy complicada, ya que los intereses norteamericanos para la zona contravienen los objetivos saudíes regionales que debilitan la figura del monarca como líder árabe y musulmán. Desde la perspectiva saudí, lo único positivo de aquella doctrina es que Irán e Irak entraban en esa categoría de regímenes que podían auspiciar a terroristas, por lo que quedaban bajo el punto de mira norteamericano. Y eso debía quedar muy claro, por lo que los saudíes no desaprovechaban ninguna ocasión para

\footnotetext{
${ }^{79}$ Echevarría, op. cit., p. 19.
} 
recalcarlo. Así ocurrió, por ejemplo, cuando el rey Abdalá se entrevistó con el entonces asesor antiterrorista de la Casa Blanca, John Brennan, en una reunión de 2009 y en el transcurso de la conversación el rey saudí dijo que no tenía "ninguna confianza en (el primer ministro iraquí) Maliki, y que el embajador (Fraker) era muy consciente de sus puntos de vista". [...] Por esta razón, dijo el Rey, Maliki carecía de credibilidad, es un agente iraní que ha "abierto la puerta a la influencia iraní en Irak" desde que asumió el poder" ${ }^{80}$. Este tipo de observaciones eran habituales, a falta de otro tipo de "cooperación" más directa y práctica. En otra conversación, el Embajador saudí en los Estados Unidos, Adel Al Jubeir y su Encargado de Negocios, Al Jubeir destacaron las frecuentes exhortaciones del rey a los Estados Unidos para que atacasen a Irán y pusiesen fin a su programa de armas nucleares, mientras reiteraba el deseo de la Corona saudí de seguir trabajando con los Estados Unidos para hacer retroceder la influencia iraní en Irak. Tales palabras, se quedaron en eso, meras palabras, ya que se hizo patente la desconfianza y el distanciamiento político, cuando el entonces rey Abdalá criticó abiertamente la estrategia beligerante de la administración Bush contra el terrorismo, siendo los saudíes deslegitimados y hasta despreciados por los americanos.

El hecho de que los Estados Unidos intentasen quedar en un segundo plano en las revueltas de las primaveras árabes en el norte de África, su negativa a seguir apoyando al presidente Mubarak $^{81}$ y la negativa de Obama de liderar la colación internacional contra Libia, autorizada en la Resolución 1973 (2011) de 17 de marzo de 2011, del Consejo de Seguridad de la ONU auspiciada por la Liga Árabe y la Organización de la Conferencia Islámica hacían presagiar nuevos distanciamientos. El respaldo árabe en el Consejo de Seguridad fue determinante para el abandono del voto negativo, favoreciendo la abstención de los Estados más renuentes a la autorización del uso de la fuerza para intervenir en asuntos internos, como China y Rusia, pero también la India y Brasil, y así lo reconocieron expresamente China y la India ${ }^{82}$. La operación Protector Unificado iniciada el 19 de marzo por Francia y el Reino Unido con el apoyo de terceros países y con Estados Unidos "liderando desde atrás", a partir del 31 de marzo de 2011 pasó a ser liderada por la OTAN, alarmó pronto a las monarquías árabes y generó todavía un mayor clima de inseguridad, en particular, en la casa Al Saud, donde el rechazo a todo lo norteamericano se había hecho patente unos meses antes, cuando en medio de la revolución en ciernes de Egipto, el presidente Obama pidió a Hosni Mubarak que dimitiera. A pesar de los 30 años de dictadura en Egipto, para los saudíes aquella petición suponía una "traición de su antiguo socio estadounidense", lo que dejó a la casa Saud preocupada de nuevo por su propio estatus. A pesar de los esfuerzos del rey Abdalá por suavizar las tesis antiterroristas, la Casa Blanca dejó de ver a Riad a un socio y un baluarte de seguridad y estabilidad, quedando vinculado inevitablemente al terrorismo yihadista ${ }^{83}$.

El conflicto en Siria creó también importantes fricciones. Las dudas iniciales de los Estados Unidos de involucrarse en el conflicto armando o de crear una zona prohibida de sobrevuelos suscitó problemas con los saudíes que decidieron a armar a los rebeldes sirios. Posteriormente la CIA obtuvo el visto bueno para armar a los rebeldes, pero apostando por acciones más allá

\footnotetext{
${ }^{80}$ Mabon, Simon: "Muting the Trumpets of Sabotage: Saudi Arabia, The US and quest o to Securitize Iran", British Journal of Middle Eastern Studies, vol. 45 (2018), pp. 742-759, p. 755. Katherine Harvey en su libro reciente $A$ Self-Fulfilling Prophecy.The Saudi Struggle for Iraq, C Hurst \& Co Publishers Ltd, señala que los miembros del nuevo gobierno de Irak inicialmente buscaron establecer una relación positiva con Arabia Saudita y no ser enfeudados por Irán, pero este intento de acercamiento fue rechazado por el rey Abdullah e Irak se quedó sin alternativas.

${ }^{81}$ Clinton Hillary Rodhan (2014): Hard Choises, New York, Simon \& Shuster, p 338-350

${ }^{82}$ Para un mayor detalle sobre aquella acción armada en Libia, López-Jacoiste Diaz, Eugenia. "La crisis de Libia desde la perspectiva de la responsabilidad de proteger", Anuario Español de Derecho Internacional, XXVII, (2011), pp.109-152.

${ }^{83}$ Clinton op.cit; Hernández Martinez (2020), op. cit., p. 53.
} 
de las armas, dinero, propaganda y entrenamiento a la oposición, tal y como venían haciendo los saudíes. Sus acciones se hicieron públicas el 30 de abril de 2013, antes de John Kerry viajara a Moscú para discutir con el presidente Putin del tema de Siria y del uso de armas químicas a pequeña escala. En agosto, tuvo lugar el ataque del gobierno sirio con armas química en Goutha, acto que sin duda traspasó la línea roja que el presidente Obama había establecido con anterioridad. A pesar de la gravedad, no hubo represalias militares por parte de los Estados Unidos, cuestión que produjo una profunda irritación en Arabia Saudita. Tras el surgimiento del Daesh, los Estados Unidos formó una coalición para combatirlo militarmente, pero los saudíes acabaron haciendo una contribución casi simbólica desde el punto de vista militar, por lo que el valor de Arabia Saudita como socio militar para Estados Unidos se redujo considerablemente. ${ }^{84}$

Otros actos de Obama tampoco ayudaron a la reconciliación; al contrario, parece que su alianza llegaba a su fin, cuando en 2015, se firmó el acuerdo nuclear con Irán, aunque dicho acuerdo suponía paso crucial para contener, e incluso detener, que Irán pudiera un día conseguir el arma nuclear. Su contenido tenía una doble lectura para los antiguos socios: Washington obtenía un logro político y Riad una grave decepción, al considerar que el acuerdo ofrecía legitimidad, crecimiento económico a Irán, acceso a más de 100.000 millones de dólares de activos congelados y nuevas alas para su liderazgo en la región, aunque limitase su capacidad nuclear, cuestión ésta última que favorecía a Riad ${ }^{85}$. A partir de entonces, la política exterior saudí ratifica lo que ya se sospechaba años antes con Bush, que Washington adopta decisiones importantes que afectan directamente a Riad, pero sin su consentimiento y sin tenerlo siquiera en cuenta, a pesar de ser un interlocutor en teoría cercano y necesario. Se confirma, por tanto, que la monarquía saudí ya no cuenta con la Casa Blanca para garantizar su política y seguridad dentro y fuera de la región.

Bajo el mandado de Donald Trump se abre un nuevo escenario en el que ambas partes intentan relajar las tensiones del pasado y se produce un cierto grado de acercamiento. La administración Trump se caracterizó desde la toma de posesión del nuevo presidente por la ruptura con el establishment. Pues, en efecto, en contra de las tradiciones estadounidense, Trump hizo su primer viaje oficial al extranjero a Riad, donde sus anfitriones lo festejaron con una danza tradicional de espadas y un extraño orbe resplandeciente. En respuesta a tal consideración, Trump se negó obstinadamente a criticar al Reino, e incluso ayudó a protegerlo de las consecuencias del asesinato de Khashoggi. Los primeros actos amistosos bilaterales son de carácter económico y comercial, con lo que se vaticinaba un reencuentro en temas de mayor calado político. Trump apoyó los programas del rey Salmán y el Príncipe heredero en materia de seguridad en la zona, rearme y modernización de las fuerzas armadas saudíes firmando acuerdos por un montante de 400.000 millones de dólares de los que 110.000 millones correspondían a compras del sector Defensa. En consecuencia, Riad mantuvo su estatus quo de líder en la región y ahora además bien pertrechado militarmente, mientras que Washington creaba al mismo tiempo un nuevo eje regional con Israel, Egipto y las monarquías árabes, con Arabia Saudí, entre ellas. El elemento clave de este nuevo eje era la amenaza iraní; mientras que otros temas candentes y diplomáticamente conflictivos se quedaron deliberadamente al margen de sus conversaciones, en concreto, la guerra en Siria, el conflicto palestino-israelí o la intervención en Yemen. De esta forma, la nueva alianza entre Arabia Saudí y los Estados

\footnotetext{
${ }^{84}$ Clinton, op.cit. pp. 446-470; Kerry, John (2018): Every Day is Extra, New York, Simon \& Shuster, pp. 524555; Carter, Ash (2019): Inside the Five-Sided Box, New York, Penguin, pp. 295-297.

${ }^{85}$ Kerry, John, Ibid.; Legranzi, Matteo: "Shaking things up: Gulf security after Iran deal”, INSSSL Defence Review Colombo, Institute of National Security Studies Sri Lanka, vol. 1 (2017), pp. 41-48; “Arabia Saudí apoya decisión de Trump de retirarse del pacto nuclear con Irán”, La Vanguardia, 8 de mayo de 2018, en https://www.lavanguardia.com/vida/20180508/443428775602/arabia-saudi-apoya-decision-de-trump-deretirarse-del-pacto-nuclear-con-iran.html
} 
Unidos o, mejor dicho, entre Mohamed bin Salmán y Donald Trump, fue puntual y ad hoc, pero bastante alejada de aquel matrimonio de conveniencia de 1945.

La retirada unilateral de los Estados Unidos del Plan de Acción Integral Conjunto, el 8 de mayo de 2018, fue el elemento clave de una renovada alianza tácita de Trump con la Corona saudí, ya que - ante la falta del acuerdo vinculantes, en consecuencia - los Estados Unidos restablecieron sus sanciones contra Irán, ${ }^{86}$ y todo ello a pesar de que el Plan había sido corroborado por unanimidad en el Consejo de Seguridad en su Resolución 2231 (2015) de 20 de julio ${ }^{87}$. No hay que llevarse a engaños, puesto que las acciones de Trump no formaban parte de un plan pactado con el Príncipe heredero, solo respondía a su "America first", aunque en este caso el estilo Trump favoreciera igualmente a los intereses saudíes. A pesar de la sorprendente diplomacia estadounidense de aquellos años, algunos expertos creyeron que los lazos entre los Estados Unidos y Arabia Saudita conseguirían capear finalmente el temporal, como ya lo habían hecho en otras ocasiones, debido a la necesidad de una sólida y duradera coalición anti-iraní que consolidase los intereses de ambos Estados en Oriente Medio. Sin embargo, los analistas políticos no se ponen de acuerdo a la hora de valorar la nueva relación entre norteamericanos y saudíes. Según Bilal Saab, analista del Instituto de Oriente Medio y ex asesor del Departamento de Defensa de Estados Unidos, es "realmente difícil, si no impensable, pensar en un colapso o un divorcio" de las relaciones entre Washington y Riad ${ }^{88}$. En cambio, Bruce Riedel, experto en Arabia Saudita y veterano de la CIA, asume que existe un posible punto de ruptura en el horizonte, puesto que ya había habido importantes altibajos en sus relaciones, y que ningún país extranjero había infligido tanto dolor económico a los americanos como lo hizo Arabia saudí en 1973 con la crisis del petróleo, cuando los sauditas aumentaron en un $400 \%$ su precio dentro de la OPEP, lo que provocó una crisis económica en Occidente que aún está por superar ${ }^{89}$.

De forma muy escueta y gráfica, pero con gran realismo, algunos medios de comunicación señalaron que Trump pasó cuatro años coqueteando con los saudíes, que le ayudaron también a desbloquear el acuerdo de paz entre Israel y diversos Estados árabes, mientras que Biden puede marcar el comienzo de una era de cordialidad helada ${ }^{90}$. Muchas de las tensiones bilaterales tienen que ver también con las políticas de Arabia Saudita contra los disidentes y la persecución de activistas en el extranjero, como el asesinato de Yamal Khashoggi y el espionaje en Twitter. Pero aún y todo, ni Biden ni sus asesores sobre Oriente Medio, tienen un plan concreto ni completo para transformar radicalmente sus relaciones con Arabia Saudita ${ }^{91}$. La política exterior de los Estados Unidos no puede cambiar de forma radial con el cambio del inquilino de la Casa Blanca. Si bien cambian las formas diplomáticas, Biden podría intentar debilitar los puntos coincidentes con los saudíes que no sean de su agrado, pero no parece estar dispuesto a imponer sanciones ni a rebajar las relaciones con Arabia Saudita. Podría incluso

\footnotetext{
${ }^{86}$ Para un análisis detallado de estas cuestiones, véase Pozo Serrano, Pilar: "La retirada de Estados Unidos del Plan de Acción Integral Conjunto y la reimposición de sanciones a Irán: aspectos jurídicos y políticos”, Anuario Español de Derecho Internacional, vol. 35 (2019), pp. 219-259; Bermejo García, Romualdo y Gutiérrez Espada, Cesáreo: "El programa nuclear iraní en el ojo del huracán”, Revista Española de Derecho Internacional, vol. 57, $\mathrm{n}^{\mathrm{o}}$ 1, (2005), pp. 105-119; Joyner. Daniel H. (2016): Iran's nuclear program and the international law: from confrontation to accord, New York, Oxford University Press.

${ }^{87}$ Actas de la $7488^{a}$ sesión del Consejo de Seguridad de las Naciones Unidas sobre el debate del Plan de Acción Integral Conjunto y de la resolución 2231 (2015), S/PV.7488, de 20 de julio de 2015.

${ }^{88}$ Johnson, Keith and Gramer, Robbie. "How the Bottom Fell out of the U.S.-Saudi Alliance", 23 April 2020, en https://foreignpolicy.com/2020/04/23/saudi-arabia-trump-congress-breaking-point-relationship-oil-geopolitics/ ${ }^{89}$ Ibid.

${ }^{90}$ Smith, Saphora and De Luce, Dan: "U.S.-Saudi ties were especially close under Trump. Biden, the looks likely to change", 12 November 2020, en https:/www.nbcnews.com/news/world/less-privileged-personal-how-u-ssaudi-ties-may-soon-n1247439

${ }^{91}$ Farouk, Yasmine: "Saudi Arabia’s Foreign Policy”, op.cit.
} 
aparcar el caso Khashoggi en aras a frenar el acercamiento de Riad a Moscú. Así se desprende de los informes de desclasificados de la inteligencia estadounidense, cuya Administración parece estar decidida a preservar la relación saudí evitando el castigo directo del propio Príncipe a pesar de las demandas de algunos demócratas del Congreso y aliados de Khashoggi de sanciones significativas y específicas. Por el momento, no está nada claro cómo planea avanzar esta nueva etapa de la administración Biden ${ }^{92}$.

Es un hecho constatable, que las relaciones Arabia Saudí y Rusia se están intensificado, al menos desde que en 2019 ambos países firmasen una veintena de acuerdos en diferentes ámbitos, como la energía, la sanidad, el turismo y la cultura entre otros, durante la visita del presidente ruso, Vladímir Putin, al reino para estrechar la cooperación bilateral, tras el viaje del rey Salman bin Abdelaziz a Moscú en $2017^{93}$. Hay que recalcar las palabras del príncipe Abdelaziz bin Salman, ministro de Energía saudí, en el momento de la firma de aquellos acuerdos cuando aseguró que los dos países habían empezado una "nueva etapa en sus relaciones a varios niveles" y señaló que los pactos suscritos en 2019 eran "una extensión" de los rubricados en 2017, por lo que no se descartaba nuevos acuerdos en otros sectores, en un futuro no muy lejano, dando a entender así su búsqueda de nuevos socios comerciales para el suministro de armas. Las autoridades saudíes sostienen que "unas relaciones estrechas con los Estados Unidos, China y Rusia no son excluyentes". Dicho y hecho. En la séptima edición del Foro Técnico-Militar Internacional, Army 2021, la mayor exhibición estática y dinámica de sistemas de armas y material de defensa del complejo industrial-militar aeroterrestre y naval de la Federación de Rusia, el viceministro de Defensa del Reino saudí, el príncipe Khalid bin Salman, anunció un acuerdo para desarrollar la cooperación militar conjunta entre los dos países, que firmó junto con su homólogo ruso, el coronel general Alexander Fomin. El viceministro también se reunió con Sergey Shoygu, el ministro de Defensa ruso, y discutió nuevas formas de mejorar la cooperación militar entre las dos naciones ${ }^{94}$. Las relaciones militares Riad-Moscú son cada vez más estrechas como consecuencia de la firma de otro acuerdo sobre la producción de armamento en territorio saudí. La corporación rusa Rosoboronexport y el consorcio militar saudí ya cuentan también con un memorándum sobre la compra de los derechos de fabricación de equipos militares ruso en Arabia Saudí. Además, ambas compañías estatales firmaron un contrato para la producción de fusiles Kaláshnikov A-103 y de munición en el país árabe. Otro de los acuerdos entre Rusia y Arabia Saudí contempla que la primera provea a la segunda de sistemas de lanzamiento de misiles antiaéreos S-400, conocidos como Triumph, los proyectiles son las novísimas armas que Moscú emplea en la guerra siria, considerados por los expertos como la pesadilla de los pilotos. Sin duda, la compra de los S-400 puede ser motivo de preocupación en los Estados Unidos, quien- en teoría - es el principal aliado de la monarquía saudí. Estos acuerdos son un claro ejemplo de las tensiones existentes entre ambos socios no solo son políticas, sino también militares.

Tanto el Príncipe heredero como la administración Biden deberán ser pacientes, ya que, en la situación actual de la zona, con un Irán a un lado y con Turquía al otro, Arabia Saudí no tiene muchas alternativas para elegir socios fiables desde el punto de vista geopolítico. Basta con observar, cómo el ministro de Asuntos Exteriores ruso, Serguei Lavrov, decidió visitar Arabia Saudí, los Emiratos Árabes Unidos y Catar para evaluar de cerca la situación y ver si podía ocupar el vacío que los Estados Unidos está dejando en la zona, pero, en cambio, como era

\footnotetext{
${ }^{92}$ Miller, David A: "The Future of U.S.-Saudi Relations Following Report Tying Khashoggi Killing Approval to Crown Prince, 1 March 2021 en https://archive.kpcc.org/programs/airtalk/2021/03/01/66544/the-future-of-ussaudi-relations-following-report/

93 “Arabia Saudí y Rusia sellan veinte acuerdos durante la visita de Putin”, La Vangardia, 14 de octubre de 2019.

${ }^{94}$ Hadifi, Meryen: "La nueva geopolítica rusa en Oriente Medio", Atalayar, 24 agosto 2021, en https://atalayar.com/content/la-nueva-geopol\%C3\%ADtica-rusa-en-oriente-medio
} 
lógico esperar, no se acercó ni a Estambul ni Jerusalén ${ }^{95}$. El que fuera vicepresidente de Obama debe decidir ahora como quiere restablecer las relaciones estadounidenses en la zona. Durante su campaña electoral fue duro con Arabia Saudí, aunque tras la toma de posesión, el nuevo presidente, Joe Biden, rebajó el tono de su desaprobación con ciertas prácticas, pero criticó la catástrofe humanitaria y estratégica de la guerra en Yemen, y advirtió que, aunque seguiría vendiendo armas defensivas a Arabia saudí , "pondría fin a todo el apoyo estadounidense a las operaciones ofensivas en la guerra de Yemen, incluidas las ventas de armas relevantes" $" 96 \mathrm{Si}$ este anuncio se hace realidad, obstaculizará considerablemente la maquinaria de guerra saudí, aunque en la actualidad Arabia Saudita ya cuenta con todos los tanques y aviones de guerra que necesita. La posición de Joe Biden podría cortar el suministro de municiones, incluido un mega acuerdo de última hora para bombas firmado por Donald Trump en diciembre 2020, y los repuestos. Los detalles del nuevo rumbo que adquiera de política de Biden serán importantes. Si corta el flujo de bombas "inteligentes", los saudíes se verán obligados a depender de otras bombas más simples, pero igualmente dañinas, aunque ofrezcan un menor apoyo a los yemeníes. Pero Biden podría ir más allá: la cuestión no son solo las armas, sino los medios para usarlas, ya que bajo la administración Trump no se detuvo la práctica de repostar aviones para la coalición liderada por Arabia Saudita en Yemen, y continuó brindando "asesoramiento militar e información limitada, logística y otro apoyo", según la Casa Blanca. Si los Estados Unidos dejan de mantener los aviones saudíes, el 50\% de la fuerza aérea del Reino saudita podría verse afectada, según los datos del análisis de Tom Beckett, el director ejecutivo del Instituto Internacional de Estudios Estratégicos ${ }^{97}$. La decisión de Biden, no obstante, transciende la cuestión del armamento y tendrá sus consecuencias en la ya de por sí problemática relación de los Estados Unidos con Arabia Saudita, entre las que no se descarta un cierto "efecto rebote" contraproducente que cambie el punto de mira de la Corona Saud hacia Oriente. De momento, Biden - en marcado contraste con la administración Trump -está tratando estos temas directamente con el enfermo Rey Salman en lugar de con Mohamen bin Salman, a través del secretario de Defensa Lloyd Austin y el príncipe Khalid, actual viceministro de Defensa saudí ${ }^{98}$.

A lo largo de estos 76 años de relaciones bilaterales de conveniencia mutua, los estadounidenses pueden estar exasperados con los saudíes, pero eso no significa que Arabia Saudí hayan dejado de ser un poderoso productor de petróleo, incluso en las circunstancias actuales, que es miembro del G20 y un socio importante para la lucha contra el terrorismo. Y todo esto no puede romperse por pura estrategia política ni norteamericana ni saudí. En su lugar, Biden tendrá que encontrar un nuevo enfoque, uno que no se entregue a los peores impulsos del Reino ni refuerce sus peores temores.

\subsection{La tradicional rivalidad entre Arabia Saudí e Irán y ¿su posible superación?}

Uno de los principales escollos de la política exterior saudí es el impacto negativo que tiene en la región su rivalidad histórica con Irán por la influencia regional en el Golfo Pérsico y Oriente Medio en general. Esta "histórica rivalidad" es un fenómeno relativamente reciente - desde la revolución iraní de 1979 -, pero irreconciliable, al menos así se pensaba hasta hace pocos meses. Tanto Irán, como Arabia Saudí son Estados poderos que se valen de la dialéctica

\footnotetext{
${ }^{95}$ Dorsey, James M.: The Russian FM's Gulf Tour. A Bellwether of US Saudi Relations, The Begin-Sadat Center for Strategic Studies, Besa Center Perspectives Paper nº 1956, 9 March 2021.

96 "Joe Biden puts Saudi Arabia on notice", The Economist, 5 February 2021, en https://www.economist.com/middle-east-and-africa/2021/02/05/joe-biden-puts-saudi-arabia-on-notice

97 "Joe Biden looks to end the war in Yemen, The Economist, 11 February 2021 en https://www.economist.com/middle-east-and-africa/2021/02/13/joe-biden-looks-to-end-the-war-in-yemen

${ }^{98}$ Herdenson, Simon: "Saudi visit to Washington will have a thorny agenda", 6 July 2021, en https://www.washingtoninstitute.org/policy-analysis/saudi-visit-washington-will-have-thorny-agenda
} 
religiosa para justificar y legitimar una lucha feroz por el dominio regional, con acciones políticas nacionales e internacionales de calado que demuestran la gran distancia existente entre sunníes y chiíes, lo que hacen muy difícil una posible solución ${ }^{99}$. Este cisma religioso se ve reflejado en el resto de Oriente Medio, también dividido entre chiitas y sunitas, por lo que el resto de países de la región buscan apoyo y orientación en Irán o Arabia Saudita dependiendo de su inclinación religiosa. Ambos países se arrogan el derecho de hablar por todo el mundo musulmán y tienen ambiciones hegemónicas en la región, si bien, cada uno de ellos lo justifica por diversos motivos: Irán es mucho mayor en cuanto a población, mientras que Arabia Saudí produce mucho más petróleo.

En los últimos años, se ha visto agravada su particular "guerra fría" que carece de enfrentamientos bélicos directos en sus respectivos territorios ${ }^{100}$, a pesar de que existen muchas tensiones y conflictos indirectos contra Irán o sus aliados, por motivos religioso de fondo, pero con manifestaciones geoestratégicas y económicas muy distintas. Con el tiempo, el enfrentamiento se ha hecho más geopolítico y social que estrictamente religioso, aunque las diferencias religiosa originarias siguen ahí y son la excusa para enconar aún más la rivalidad, que se manifiesta y agudiza con ocasión de los diversos conflictos que se suceden en la región, en particular, con la intervención en Irak en 2003, el fin del régimen de Sadam Hussein (árabe sunnita) y la "reconstrucción" del país; pero sobre todo por los apoyos directos e indirectos a los diversos grupos beligerantes en la guerra en Siria y en Yemen.

En efecto, la invasión estadounidense de Irak en 2003 y la eliminación del régimen de Saddam Husein en Bagdad alteró de forma fundamental el equilibrio de poder en el Golfo Pérsico, ya que, mientras Sadam gobernaba Irak servía de contrapeso político al poder iraní. Con su derrocamiento se eliminó igualmente su contrapeso militar y se abrió el camino para un Gobierno dominado por chiitas en Bagdad. Precisamente por temor a ese resultado, los saudíes habían apoyado a Saddam en su guerra contra Irán entre 1980 y 1988, aunque no se fiaban ni del sistema, ni de Saddam Husein. Incluso después de la invasión de Kuwait en 1990, Irak también sirvió de zona de amortiguación entre Irán y Arabia Saudí. La caída del régimen de Saddam Husein y la incapacidad de los Estados Unidos de construir un régimen iraquí estable que le sucediera, hicieron que Irak pasara de ser "actor" protagonista a "campo de batalla" en el juego por el poder en Oriente Medio. Los saudíes cobraron consciencia de lo dañina que podía resultar la situación para sus intereses, si los chiíes se hacían con el poder en este país tan cercano que pudiera alterar su posición dominante en la región, y todo esto explica sus primeras maniobras anti iraníes y anti chiíes ${ }^{101}$.

Para algunos, el colapso de Irak supuso una reafirmación de facto del poder iraní, lo que conlleva a una mayor preocupación entre los países árabes y explica cómo la pugna y competencia entre Arabia Saudí e Irán por su influencia sobre Irak sirven de patrón para su

\footnotetext{
${ }^{99}$ Mikaïl, Barah: "Geopolítica del conflicto entre sunníes y chiíes: una visión global”, Revista de análisis y pensamiento sobre el mundo árabe e islámico contemporánea, $\mathrm{n}^{\circ} 8$ (2013), pp. 1-17.

${ }^{100}$ Sobre esta cuestión conviene hacer un pequeño maíz, ya que en el territorio iraní sí que existe un conflicto armado, de carácter asimétrico y de baja intensidad, en la provincia de Sistán y Beluchistán. La contienda enfrenta a Irán y varias organizaciones militares sunnitas de Beloch, consideradas como terroristas por Teherán. A pesar de su baja intensidad, Arabia Saudí parece estar detrás de algunas ellas, financia a tales grupos y no descarta desplegar mayores operaciones. En consecuencia, Teherán teme que Pakistán permita a Riad la utilización del puerto de Gwadar, que está cerca de la frontera iraní, como plataforma de lanzamiento para emprender operaciones militares de desestabilización. Véase Domínguez Diaz, Francisco Antonio: "Monográfico sor el mundo árabe", en Libia Arenal Lora (coord.) (2020): Estudios contemporáneos sobre geopolítica, conflictos armados y cooperación internacional, Universidad Internacional de Andalucía, pp. 132-133.

${ }^{101}$ James G. Blight et al. (2012): Becoming Enemies U. S.-Iran Relations and the Iran-Irak War, 1979-1988. Lanham (Maryland), Rowman \& Littlefield Publishers.
} 
rivalidad regional más amplia ${ }^{102}$. El mismo enfrenamiento geopolítico se aprecia en las fragmentadas políticas internas de los Estados árabes más débiles: el Líbano, los Territorios Palestinos, Yemen, así como Irak. Cada bando apoya a sus aliados locales con la esperanza de que estos lleguen al poder, como Al-Maliki en Irak, y se inclinen hacia su patrón extranjero. Entre los aliados de Irán están Hezbollah en el Líbano y hasta cierto punto Hamás en la Franja de Gaza. En cambio, entre los aliados de Arabia Saudí están la Autoridad Palestina y los partisanos sunníes del anterior primer ministro Saad al-Hariri en el Líbano, ahora amenazados por una poderosa tendencia salafista apoyada abiertamente por Riad. Arabia Saudí también apoya a varios jeques tribales y figuras políticas sunníes en Yemen, Siria e Irak. Pero ni Riad ni Teherán suponen una amenaza militar real para sus vecinos, ya que el Reino saudí no es precisamente fuerte militarmente hablando, hasta tiempos muy recientes gracias al impulso de Trump ${ }^{103}$, aunque su poderío se hace notar en Yemen. Tradicionalmente su ejército era bastante pequeño e inexperto y había salido pocas veces de sus fronteras a excepción de una corta y fracasada experiencia contra los rebeldes hutíes en Yemen del norte entre noviembre de 2009 y febrero de 2010. El ejército iraní siempre ha sido más grande y tiene más experiencia en el campo de batalla debido a su guerra con Irak en los años 80, pero tampoco es una verdadera amenaza ofensiva con la excepción de los misiles balísticos no convencionales y el programa de enriquecimiento nuclear que no tiene otro fin que el arma disuasoria, cuya problemática particular también está presente en las relaciones entre Riad y Teherán, aunque de forma más tangencial.

Ni Irán ni Arabia Saudí sufrieron una "primavera árabe" entre sus ciudadanos ni en sus territorios, por razones obvias, pero aprovecharon las revueltas y conflictos en los vecinos para expandir su influencia, especialmente en Siria y Yemen, lo que aumentó aún más su rivalidad y desconfianza mutua.

El Gobierno saudita vio en la guerra en Siria una oportunidad para desbancar al presidente Al-Assad, que era más cercano al poder iraní. Los Saud eran conscientes que de conseguir que grupos afines al Reino llegaran al poder podría producir dos resultados positivos: por un lado, aumentaría su influencia en esa área concreta que había sido tan crítica con Riad; y, por otro lado, cortar el eje iraní, que unía Teherán con Bagdad, Damasco y Beirut. Ante ese panorama, varios países del Golfo han estado financiando a la oposición islamista del régimen de Assad, entre ellos también Arabia Saudí. Su participación en el conflicto tenía un claro objetivo: un cambio de régimen por lo que su acción directa se ejecutó según una doble estrategia: por una parte, apoyando a los grupos insurgentes contrarios a Bashar Al-Assad, incluido el Frente Al Nusra vinculado a Al Qaeda, en la medida en que sus conquistas terrestres debilitaban a Assad; y por otra, apoyando activamente la campaña militar de la coalición internacional liderada por los Estados Unidos, cuya finalidad también era el fin de la era Assad $^{104}$. Además, existe una pequeña, aunque no despreciable sección de la población saudí simpatizante con Al Qaeda y el Estado Islámico, hecho que no sorprende dado el

\footnotetext{
102 Dazi-Héni, Fatiha: “Arabia Saudí contra Irán: un equilibrio regional de poder”, Revista de análisis y pensamiento sobre el mundo árabe e islámico contemporánea, ${ }^{\circ} 8,(2013)$, p23-35, p. 24.

${ }^{103}$ Recuérdese, como, por ejemplo, en 2017, los Estados Unidos firmó con Arabia Saudí un jugoso contrato de venta de armas por un valor de 100.00 millones de dólares. Salvando las distancias cuantitativas de los contratos de armas, también España tienes intereses comerciales con Riad, que han esto a punto de fracasar. En verano de 2018, el Gobierno español congeló de facto las exportaciones de armamento a Arabia Saudí y no autorizó ni un solo contrato de venta a este país durante el resto del año. Los datos de exportaciones de 2019, sin embargo, muestran cómo, tras ese primer semestre, el Ejecutivo multiplicó por 30 las autorizaciones para exportar a Riad: de los 13,2 millones autorizados en 2018, se pasó a más de 392 millones en 2019.

104 Priego Moreno, Alberto: "La nueva política exterior de Arabia Saudî", Instituto Español de Estudios Estratégicos, Documento marco, $\mathrm{n}^{\circ} 18$ (2015), pp. 1-20, p. 15, en http://www.ieee.es/Galerias/fichero/docs_marco/2015/DIEEEM182015_NuevaPoliticaExterior_ArabiaSaudi_A.Priego.pdf
} 
adoctrinamiento wahabí al que los saudíes se encuentran sometidos desde hace años. De ahí que muchos conservadores saudíes viesen con buenos ojos a $\mathrm{Al}$ Qaeda y al Estado Islámico como una forma "más pura" del islam, despojada de la corrupción interna de la familia real saudí y de su alianza con las potencias occidentales infieles. Como consecuencia y pese al decreto real que criminaliza a quienes combaten en el extranjero, según las Leyes Básicas de 1992, no pocos ciudadanos saudíes fueron combatientes voluntarios del Estado Islámico, pero también del Frente Al Nusra vinculado a Al Qaeda.

Los saudíes están muy presentes en la guerra de Yemen, echando así otro pulso claro y directo a Irán. El conflicto armado en el que se encuentra Yemen desde 2011 se reaviva en 2014 con la intervención de Arabia Saudí como uno de sus principales contendientes. Pero la conexión saudí con la sociedad y política yemení, al margen incluso de la hostilidad abierta y conocida contra Irán, se canaliza por cuatro vías: 1) la relación directa con el Gobierno y Saleh; 2) los programas de ayuda económica y cooperación comercial; 3) la expansión del wahabismo entre creyentes sunnitas; y 4) el contacto directo entre la diplomacia saudita y los líderes tribales. Ya en el año 2000, Arabia Saudí mantuvo negociaciones bilaterales para intentar arreglar su litigio fronterizo con su vecino Yemen - unos $1.350 \mathrm{~km}$ de fronteras -, aunque aquel acuerdo aún está pendiente de aplicación. Pero el acto determinante que propició la intervención armada saudí en Yemen fue la disolución del Parlamento yemení y el arresto domiciliario de su presidente, por lo que Mohamed bin Salmán organizó y lideró la campaña militar, puesto que era el ministro de Defensa desde que su padre accedió al trono. La intervención decisiva fue en 2015, en la operación Decisive storm, donde Arabia lideraba la coalición contra los rebeldes hutíes - formada por países de Oriente Medio como Emiratos Árabes Unidos o Kuwait y otros africanos como Egipto- persiguiendo varios objetivos: en primer lugar, limitar la influencia del chiismo en Yemen, personificada en los hutíes, y así contrarrestar el poder de Irán; y, en segundo lugar, mantener en Yemen un gobierno afín a los intereses estratégicos saudíes. Sin embargo, la escalada de tensiones entre ambos países no responde solo a la búsqueda de posibles objetivos de pacificación del país, tutelados por las Naciones Unidas ni por los intentos de la Conferencia del Golfo desde 2012. Tampoco persigue el restablecimiento del Gobierno en Saná, mediante un diálogo entre todas las facciones del país, desde el Gobierno de Saná hasta los hutíes del norte o los independentistas del sur. Responde - una vez más - a la pugna por el peso político de ambas potencias, ya que Irán había apoyado constante a los rebeldes hutíes, mediante el suministro de armas en su lucha contra el Gobierno central de Abdo Rabu Mansur Hadi, a quien apoyaba Arabia Saudí. En esta lucha de poder el factor religioso recobra importancia, ya que los hutíes profesan el zaidismo, que - aunque no es la rama del chiismo instaurado en Irán, es contraria al wahabismo, razón por lo cual la confrontación con Arabia Saudí implica el elemento más relevante a la hora de explicar el apoyo iraní. El avance de los hutíes en el norte y en las zonas montañosas colindantes con Arabia Saud preocupa más a la casa Saud que el avance de los yihadistas, como la organización terrorista Al Qaeda en la Península Arábiga (AQAP) que aprovecha toda confusión para seguir ampliando su capacidad de maniobra, estableciendo su red territorial, que ni las fuerzas de seguridad yemení ni los drones estadounidenses son capaces de frenar. A finales de marzo de 2015, con Hadi rodeado por los hutíes y la creciente beligerancia del Daesh y Al Qaeda, Arabia Saudí decide dar un paso más y respaldar por la fuerza al Gobierno yemení. Junto a la ya mencionada Operación Tormenta Decisiva (Operation Decisive Storm), la intervención militar saudí desplegó la Operación Restaurar Esperanza (Operation Restoring Hope). Ambas operaciones perseguían evitar el vacío de poder y el aumento de la inestabilidad en Yemen y evitar por todos los medios que el Estado yemení fuese el caldo de cultivo idóneo para el crecimiento de grupos radicales y terroristas, cuyas ideas y acciones pudieran propagarse por el territorio saudí. Sin duda, semejante situación será aprovecha por Irán para ganar peso en el sur de la península arábiga. 
Sin embargo, la actual estrategia de Arabia Saudí se encuentra ante una paradoja aparente: por una parte, el Reino ha hecho visible su voluntad de poner fin a su campaña militar en Yemen, ante la insistencia de Biden de reavivar el impulso internacional y regional para alcanzar un cese de las hostilidades. Si los saudíes secundan el impulso norteamericano sobre esta cuestión, se conseguiría frenar el constante languidecimiento de la percepción de que los norteamericanos ya no son proveedores de seguridad del reino. Por otra, el constante apoyo de Irán a los hutíes -y del movimiento libanés Hezbollah- al sur de sus fronteras son una amenaza permanente a su seguridad y estabilidad. De ahí que los saudíes parecen estar abocados a dar preferencia a la diplomacia $^{105}$, antes que a las armas para intentar apaciguar los ánimos de todas las partes beligerantes, en particular de los Emiratos Árabes Unidos, como veremos más adelante. Sin embargo, los motivos que llevaron a intervenir en Yemen siguen presentes y son muy relevantes, desde el punto de vista doméstico saudí: la necesidad de proyectar una imagen exterior fuerte y al mismo tiempo preservar el estatus nacional e internacional, lo que impediría su retirada de Yemen, sin antes lograr un resultado que pueda presentarse como una "victoria" o una "no derrota".

Al incido de este apartado, señalábamos que la rivalidad entre Arabia Saudí e Irán, tenía carácter irreconciliable, y desde luego, el asesinato de Khashoggi fue una de las muchas víctimas de esta rivalidad de larga data, aunque no será la última ${ }^{106}$. Al menos así se pensaba hasta hace unos meses. A lo largo del 2021 se ha dado ya algunos pasos que hacen presagiar que quizás esa realidad esté empezando a cambiar ${ }^{107}$. El 10 de mayo de 2021, cuando el mundo entero miraba con estupor las acciones bélicas entre israelíes y palestinos en la Franja de Gaza liderados por Hamás, el príncipe heredero Mohamed bin Salmán y el presidente de Irán, Hassan Rouhani mantuvieron una reunión presencial - que no virtual - para iniciar un nuevo e insólito diálogo tras 40 años de tensiones por imponer en el mundo musulmán la supremacía de su propia rama del islam. Los primeros contactos diplomáticos fueron secretos y comenzaron en enero de 2021 en Bagdad, con el propósito de buscar "una relación buena y especial con Irán", tal y como lo expresó el mismo Mohamed bin Salmán ${ }^{108}$. Al no tratarse de un mero encuentro puntual, sino que prosiguen las conversaciones entre ambos países, los líderes saudíes están sugiriendo que la diplomacia puede tener más posibilidades de lograr su objetivo de contener a Irán que la confrontación.

De hecho, las negociaciones directas entre Teherán y Riad, que se iniciaron en abril, han dado lugar a la aprobación de una hoja de ruta con diversos temas y la realización de cuatro rondas negociadoras, la última de las cuales ha tenido lugar el 21 de septiembre. Aunque las discusiones se encuentran todavía en un estado exploratorio, se pretende establecer las bases para un acuerdo global. No se esperan rápidos avances en los distintos dosieres, pero el nuevo proceso rebajará las tensiones.

\footnotetext{
${ }^{105}$ Bordón, Javier: "El conflicto de Yemen y Arabia Saudí: sin influencia para resolver, pero con motivos para no hacerlo", Real Instituto Elcano, ARI, 70/2021, p. 2, en

http://www.realinstitutoelcano.org/wps/wcm/connect/90e4efcb-24d8-4616-b325-fa0522467379/ARI70-2021-

Bordon-El-conflicto-Yemen-Arabia+Saudi-sin-influencia-para-resolver-pero-con-motivos-para-no-

hacerlo.pdf?MOD=AJPERES\&CACHEID=90e4efcb-24d8-4616-b325-fa0522467379

106 Ghattas, Kim: "What Jamal Khashoggi’s Murder Tells Us About the Saudi-Iran Rivalry”, 2 October 2019, en https://carnegieendowment.org/2019/10/02/what-jamal-khashoggi-s-murder-tells-us-about-saudi-iran-rivalrypub-79988

${ }^{107}$ Sobre estas cuestiones de futuro hay que tener máxima prudencia, pues el devenir de las tensiones políticas históricas y los conflictos armados todo puede pasar. En el momento del cierre de este trabajo - a fecha de 12 de junio de 2021 - los avances realizados hasta la fecha apuntan a nuevas perspectivas.

${ }^{108}$ Bermúdez, Ángel: “Arabia Saudí vs Irán: por qué estos archirrivales han iniciado un diálogo "sin precedentes"”, BBC News Mundo, 19 de mayo de 2021, en https://www.bbc.com/mundo/noticias-internacional-57124106
} 
Este cambio de postura tan radical puede estar impulsado por la conjunción de una serie de factores. Por una parte, por la nueva política de los Estados Unidos hacia Oriente Medio y el deseo manifiesto concreto de Biden de reducir su implicación, sobre todo militar, en esa región del mundo y que la estrategia de Biden sobre Irán ayudó a convencer a los saudíes de la necesidad de volver a calcular su propio enfoque hacia Irán ${ }^{109}$. Durante la campaña presidencial, Biden se comprometió a retirar las tropas de Afganistán, a quitar el apoyo a Arabia Saudita en la guerra de Yemen y a buscar reincorporarse al acuerdo nuclear con Irán. Y efectivamente cumplió su promesa y el pasado 2 de julio 2021, los Estados Unidos abandonan la base de militar de Bagram de Afganistán ${ }^{110} \mathrm{y}$, en su lugar, el ejército afgano toma el control del aeródromo en plena escalada de la violencia con los talibanes y a pocos días de que Washington complete el repliegue total en el país centroasiático. Según Parsi, la vicepresidente ejecutiva del Quincy Institute for Responsible Statecraft, el "factor que más impulsó a los actores de la región a seguir la ruta diplomática no es el compromiso de los Estados Unidos de respaldar a Riad contra Teherán o alguna nueva iniciativa diplomática para la región. Más bien, lo que catalizó las conversaciones es exactamente lo contrario: las cada vez más claras señales de que los Estados Unidos se está retirando de Oriente Medio" "111 Opinión y análisis reforzado con la calamitosa retirada de Estados Unidos de Afganistán

Por otra parte, ciertos cálculos saudíes estimaron que Biden iba a desarrollar una política menos agresiva con Teherán, y esto habría empujado a Riad a considerar estrategias alternativas para la región, incluida la búsqueda de un nuevo marco político para gestionar el tema de Irán. Más aún, si Biden también cumple lo anunciado de volver al acuerdo nuclear con Teherán, entonces es de suponer que Riad no querrá quedarse atrás. Ahora bien, si mejoran las relaciones entre Arabia Saudí e Irán y Teherán consigue el regreso del hijo prodigo al acuerdo nuclear, será lógico esperar que se retiren las sanciones económicas y petroleras en su contra ${ }^{12}$, tanto las norteamericanas, como las onusianas y las europeas, con lo que podría resurgir un fuerte competidor económico a los sauditas en la región. En consecuencia, tampoco es descabellado pensar que en este acercamiento existen razones económicas de fondo, que, si bien no son las primordiales, tampoco son desdeñables. Toda confrontación permanente tiene su coste, seguro, aunque el secretismo en este aspecto es absoluto en Irán, y no se sabe con precisión cuánto gasta en apoyar a sus aliados en Yemen, Irak, Líbano y Siria. Sea la cantidad que sea, siempre será mucho para una economía que se encuentra sometida a fuertes sanciones desde hace ya un tiempo. Por la parte saudí, algunos datos apuntan a un enorme gasto militar que superó los US\$57.000 millones en 2020, llegando a representar el 2,9\% del gasto mundial en este sector,

\footnotetext{
${ }^{109}$ Hiltermann, Joost. "From Diatribes to Dialogue: Why Iran and Saudi Arabia Are Talking”, International Crisis Group, 7 May 2021, en

https://www.crisisgroup.org/middle-east-north-africa/gulf-and-arabian-peninsula/iran/diatribes-dialogue-whyiran-and-saudi-arabia-are-talking

${ }^{110}$ Monge, Yolanda: "EEUU hace efectiva la salida de Afganistán al abandonar la base militar de Bagram”, El País, 2 de julio de 2021, en https://elpais.com/internacional/2021-07-02/estados-unidos-se-retira-de-bagram-subase-mas-importante-en-afganistan.html

111 Parsi, Trita: "Why Mohammed bin Salman wants to talk to Iran", Foreign Policy, 29 April 2021 en https://foreignpolicy.com/2021/04/29/saudi-arabia-iran-uae-mohammed-bin-salman-secret-talks-biden-withdrawal-pivotmiddle-east/

112 Recuérdese como pocos días antes del relevo en la Casa Blanca, Trump aprobó un nuevo paquete de medidas que se añaden a la prevista desde 2018, desde la retirada del Acuerdo nuclear firmado por Obama, que buscaba la congelación del programa nuclear iraní a cambio de un alivio punitivo. Las nuevas 17 sanciones específicas contra grandes productores de acero y hierro" que, según explicó el secretario del Tesoro Steven Mnuchin, proporcionaban "millones de dólares de apoyo al régimen", por lo que las sanciones funcionan, ya que cortar la economía al régimen y tiene sin duda un gran impacto. Además, se castigó a ocho altos oficiales iraníes, entre ellos el secretario del Consejo de Seguridad Nacional Supremo, Ali Shamkhani, por su implicación en el ataque iraní con misiles contra dos bases aéreas Irak donde están desplegadas tropas estadounidenses: la de Ain Al Asad, en el oeste del país, y una en Erbil, en el Kurdistán iraquí, cometido el 9 de enero de 2020.
} 
de acuerdo con datos del Instituto Internacional de Investigación para la Paz de Estocolmo $(\mathrm{SIPRI})^{113}$.

Por último, detrás de este acercamiento se pueden esconder también otras motivaciones. En este escenario de sutil aproximación entre Riad y Teherán le está dando a Irak la oportunidad de presentarse como un facilitador de la diplomacia y ofrecerse como un lugar neutral ${ }^{114}$. Según Katherine Harvey los esfuerzos saudíes para socavar la influencia iraní, han empujado paradójicamente a Irak a caer en los brazos de la República Islámica ${ }^{15}$. La experta señala que los miembros del nuevo gobierno de Irak buscan establecer una relación positiva con Arabia Saudita con el fin de seguir un rumbo independiente de Irán, por lo que los Saud podrían enfrenarse a una nueva encrucijada y un posible cambio de rumbo. Si bien es cierto - como apunta la experta - que la percepción errónea del rey Abdullah sobre el primer ministro alMaliki como agente iraní impulsó la desconexión del Reino y debilitó su política exterior, en la actualidad al Príncipe heredero le convendría intentar superar aquellas dificultades para establecer un nuevo marco de relaciones con Irak.

Además, a los saudíes les interesa estratégicamente hablando estar en buenas relaciones con Irán, con el fin de evitar que Teherán estreche relaciones con otros países del Golfo, como, por ejemplo, con Emiratos Árabes Unidos o incluso- hipótesis hoy muy poco probable- llegue a algún entendimiento con Israel. Es más, los saudíes no descartan tampoco acuerdos con Israel a pesar de las duras criticas saudíes ante las "violaciones flagrantes" de los derechos del pueblo palestino con ocasión del enfrentamiento de mayo de 2021 entre Israel y Hamas en Gaza que hace aún más hostil el clima en la región hacia Israel. Sin embargo, a pesar de todas estas razones y a la luz de los largos años de desencuentro real y sangriento incluso, no se puede esperar que la rivalidad estratégica, religiosa y económica entre Riad y Teherán vaya a desaparecer de un día para otro. Difícilmente estas conversaciones lograrán un gran acuerdo de paz, sino más bien un marco de desescalada progresiva, con posibles concesiones mutuas y con un calendario pactado y controlado. Si los buenos oficios acompañan y las cosas marchan bien, los efectos favorables de este incipiente diálogo podrían verse, por ejemplo, en Yemen, donde las milicias hutíes podrían volverse más receptivas a una solución diplomática; o en Líbano, donde se puede facilitar un acuerdo político entre las distintas facciones para solucionar la grave crisis en ese país. Pero las acciones de Arabia Saudita en la región de los últimos años han fortalecido, en lugar de disminuir, la influencia de Irán: el boicot de Catar liderado por Arabia Saudita tuvo el efecto contraproducente de fortalecer las relaciones de Catar con Irán. La campaña militar saudí en Yemen ha resultado en una catástrofe humanitaria y ha aumentado las oportunidades para la expansión de la influencia iraní, a través de su apoyo a los rebeldes hutíes. Los saudíes ya están pensado en una cierta aproximación con Irán, pero han hecho relativamente poco para contrarrestar a los representantes iraníes en Líbano, Siria e Irak ${ }^{116}$.

Las diferencias entre saudíes e iraníes son y seguirán siendo grandes, pero el marco de una progresiva desescalada y de una nueva diplomacia permitiría que la situación sea más manejable, crearía una menor inseguridad en Oriente Medio y con mucha fortuna, podría evitar la confrontación directa.

\footnotetext{
${ }^{113}$ Lopes da Silva, Diego, and Marksteiner, Alexandra: “Trends in world military expenditure, 2020”, SIPRI Fact Sheet. (April 2021) pp. 1-12, p. 11, en https://sipri.org/sites/default/files/2021-04/fs_2104_milex_0.pdf

${ }^{114}$ Hiltermann, Joost. "From Diatribes to Dialogue... op. cit.

${ }^{115}$ Harvey, Katherine, A Self-Fulfilling Prophecy. The Saudi Struggle for Iraq, op. cit.

${ }^{116}$ Miller, David A., and Sokolsky, Richard. "Saudi Arabia is a partner, not an ally. Let's stop the charade" The Washington Post, 4 March 2021, en https://www.washingtonpost.com/outlook/2021/03/04/biden-khashoggisaudi-arabia-crown-prince/
} 


\subsection{Arabia Saudí en el Consejo de Cooperación para el Golfo}

El Consejo de Cooperación para los Estados Árabes del Golfo, creado en 1981 ha servido para impulsar la integración económica y política de las seis monarquías que lo constituyen. Pero Arabia Saudí siempre ha ejercido de primus inter pares, y ha utilizado a este Consejo (CCG) como una herramienta más de sus intereses de política exterior y para preservar su zona de influencia natural ${ }^{117}$. Un dato que manifiesta la entente armoniosa inicial del CCG y el papel de la Corona saudí fue su mediación con su vecino Catar sobre algunos puntos en litigio sobre sobre su extensa frontera terrestre desértica y lo mismo hizo con Kuwait sobre cuestiones de soberanía en aguas del Golfo Pérsico. Sin duda el caso más controvertido fue la disputa por cuestiones territoriales y marítimas existente entre los Estados de Catar y Bahréin que, a pesar de las mediación y buenos oficios de los reyes sauditas, Catar demandó a Bahréin ante la llegaría a la Corte Internacional de Justicia ${ }^{118}$. Fue la primera vez que un Estado árabe - miembro del CCG - iniciaba unilateralmente el procedimiento ante la Corte, ya que hasta entonces se había intentado solucionar las controversias de la región en el seno su propio sistema de cooperación, a través de la casa Sud, pues ese era el clima y el espíritu del CCG.

El papel de Riad en el CCG es incuestionable para la Corona Saud, aunque en ocasiones sus actos suscitan recelos y desconfianza entre sus homólogos. Pero solo Catar que, durante mucho tiempo ha estado a la sombra de Arabia Saudita, se atrevió a manifestar abiertamente su desacuerdo con la política exterior saudí y con el uso del CCG para sus intereses de liderazgo regional. En 2011 se manifestaron las primeras desavenencias y debilidades internas del CCG, ya que el Consejo carecía de los instrumentos para ser un marco operativo consolidado - y defensivo - cuando el emirato de Bahréin se vio en una situación límite. Su inestabilidad interna fue sofocada por la intervención directa de la Fuerza del Escudo de la Península, conformada principalmente por militares saudíes y policías de Emiratos Árabes Unidos. Fue el primer despliegue sobre el terreno de fuerzas en un Estado miembro para ayudar al Gobierno a contener las protestas ciudadanas. Sin embargo, aquella intervención abrió una brecha en el seno del CCG, porque no todos los miembros apreciaron aquella amenaza como tal y porque el precedente asentado - el empleo de los efectivos militares - resultaba muy peligroso si se emplea para cuestiones de seguridad interna y no solo para operaciones defensivas, tal y como correspondía originariamente ${ }^{119}$.

El siguiente gran reto para el CCG y Arabia Saudí fue la crisis diplomática con Catar de 2014 y el bloqueo económico de 2017 que durará hasta enero de 2021 y que supuso un importante obstáculo para fortalecer las interdependencias de los países miembros. La enemistad entre la casa Saud y la dinastía Al Thani se ha hecho más que evidente. Su principal escollo fue que las acciones de Catar en las primaveras árabes de Egipto, Libia y Siria fueron por libre, es decir, sin contar con el apoyo ni opinión de Arabia Saudí. Los cataríes apoyaron a los grupos rebeldes libios, sirios, pero sobre todo a los Hermanos Musulmanes en la rebelión de Egipto, lo que contrariaba las aspiraciones e intereses sauditas ${ }^{120}$. Se rompió la confianza mutua y en consecuencia comenzó un bloqueo impuso por Riad, aunque no ha sido total, ya

\footnotetext{
${ }^{117}$ Para un estudio más detallado de estas cuestiones, véase González del Miño, Paloma. y Hernández Martínez, David: "La estrategia de Arabia Saudí en el Consejo de Cooperación del Golfo. Espacios de cooperación y conflicto", Estudios de Asia y África, vol. 56 n 1 (174), 2021, pp. 5-36.

${ }^{118}$ Evans, Malcolm: "Case concerning maritime delimitation and territorial questions between Qatar and Bahrein (Qatar v. Bahrein)” The International and comparative Law Quarterly, vol. 51 (2002), pp. 709-72

${ }^{119}$ Priego, Alberto: "La Primaveras Árabes: la influencia de Catar y sus relaciones con los Estados del Golfo", op. cit., p. 239.

${ }^{120}$ Khan, Taimur: "How Qatar's Policy on the Muslim Brotherhood Burns the GCC", Nacional , 19 de marzo de 2014, en www.thenational.ae/world/qatar/20140319/how-qatars-policy-on-the-muslim-brotherhood- quema-elgcc \# ixzz39bWOE3zf .
} 
que Kuwait y Omán se mantuvieron al margen, cuando cataríes, turcos e iraníes amenazaron con acciones concretas incluso por la fuerza contra el CCG.

La rivalidad saudí-catarí ha dañado el grado de poder externo de ambos países del Golfo y ha aumentado los niveles de inestabilidad en el Oriente Medio, pero sobre todo dicha rivalidad acrecentó las tensiones entre Riad y Teherán, puesto que el bloqueo impuesto a Catar respaldado y aplaudido por los Estados Unidos por el patrocino catarí a los Hermanos Musulmanes y al terrorismo, llevaron al emir catarí a aproximarse a Teherán, para la explotación conjunta del yacimiento South Pars/North Dome que es el mayor yacimiento de gas natural del mundo. Como primera medida se restablecierosn las relaciones diplomáticas cataríes en agosto de 2017 con la república de los ayatolás, bajo mínimos desde enero de 2016, lo que supuso otro desafío para la Corona saudí. La respuesta saudí no se hizo esperar y se reforzó el bloqueo terrestre, aéreo y marítimo contra Catar por parte de Arabia Saudí, Emiratos Árabes Unidos, Bahréin y Egipto que además retiraron a sus embajadores del país catarí. El bloqueo no consiguió arruinar la economía catarí gracias al arte de las autoridades de Doha de sortear el aislamiento con la ayuda de Irán, Turquía y Omán. Esta crisis puso en evidencia, por un lado, que Arabia Saudí había fracasado en su intención de imponerse al resto de los Estados miembros del CCG y de utilizar el tema catarí como una muestra más de su poder frente a los ayatolás. Por otro, como señalan los analistas Bassima Alghussein y Jeffrey Stacey, Arabia Saudita y sus socios se habían equivocado desde el principio, ya que el bloqueo "obligó" a Catar a acudir a Irán y Turquía para la provisión de alimentos y otros productos de primera necesidad $^{121}$.

La crisis catarí ha supuesto una grave crisis interna del CCG que parecía insalvable - como otras rivalidades históricas de Arabia Saudí - aunque en los últimos meses soplan nuevos vientos de cambios y de paz. El Príncipe heredero Mohamed bin Salmán en su afán por modernizar al Reino y no perder su poder en la región, está ejerciendo un papel de experto diplomático, mejorando las relaciones con Turquía y Catar. Y, en efecto, en enero de 2021, los países del Golfo firmaron un acuerdo para poner fin a la crisis diplomática con Catar, tras una breve cumbre en la ciudad saudí de Al Ula, subrayando los "lazos de amistad y de hermandad" que son los fundamentos del CCG. En la cumbre todos los integrantes del bloqueo - Arabia Saudí, Bahréin, Emiratos Árabes Unidos, Kuwait, y Omán - hacen hincapié en la necesidad de unificar sus posturas frente a "las amenazas que supone el programa nuclear del régimen iraní, su programa de misiles balísticos y las misiones destructivas de sus agentes". Los detalles del acuerdo todavía no han trascendido, pero el ministro de Exteriores kuwaití, Ahmad Nasser al Sabá, anunció que el acuerdo firmado entre Arabia Saudí y Catar suponía la reapertura de sus fronteras marítimas, terrestres y aéreas ${ }^{122}$. El 10 de mayo de 2021, el Príncipe heredero recibió al ministro de Relaciones Exteriores de Turquía, Mevlut Cavusoglu, y al emir de Catar, Tamim bin Hamad al-Thani, prescindiendo de la polarización del pasado, y confirmando el fin de su bloqueo con Catar. Sin embargo, ha impuesto nuevas prohibiciones a las importaciones de Jordania, Líbano y Turquía, ya que, a su juicio, sus respectivos gobiernos desconfían de los posibles negocios con el reino saudí. Las reacciones internacionales no se han hecho esperar. La Unión Europea acogió con optimismo el anuncio, insistiendo en que la normalización de las relaciones entre Arabia Saudí y Catar es buena noticia para toda la región. "Es un paso importante y esperamos que sirva para restaurar la unidad en el Consejo de Cooperación para

\footnotetext{
${ }^{121}$ Alghussein, Bassima and Stacey, Jeffrey: "How Saudi Arabia Botched Its Campaign Against Qatar. The Costs of the Pressure on Doha" Foreign Affairs, 12 July 2017 en https://www.foreignaffairs.com/articles/middleeast/2017-07-12/how-saudi-arabia-botched-its-campaign-against-qatar

122 "Los países del Golfo firman un acuerdo para poner fin a la crisis diplomática con Catar", Europa Press, 5 de enero de 2021, en https://www.europapress.es/internacional/noticia-principe-heredero-saudi-recibe-emir-qatarcumbre-ccg-acuerdo-reabrir-fronteras-20210105130309.html
} 
los Estados Árabes del Golfo", ha valorado el portavoz del Servicio de Acción Exterior, Peter Stano ${ }^{123}$.

Otro foco de tensión en el seno del CCG lo constituye la división entre Emiratos Árabes Unidos y Arabia Saudí en la guerra de Yemen. Como se sabe, la coalición de países árabes liderada por Arabia Saudí y en la que participaban Emiratos Árabes, Catar, Baréin, Kuwait, Jordania, Egipto, Sudán del Norte y Marruecos, buscaba devolver la legitimidad del nuevo gobierno de Abd Rabbuh Mansur Hadi, tras el derrocamiento de Ali Abdallah Salih a raíz de las revueltas árabes del 2011. En julio de 2019, los Emiratos Árabes Unidos anunció la retirada de sus tropas de Yemen, a pesar de que siempre habían sido un actor fundamental de la coalición por sus avances desde la intervención del 2015. Su cambio de rumbo se debe a diversos factores: el incidente en el que murieron 45 soldados emiratíes en 2015; la atención privilegiada de la administración Trump hacia Irán y la aplicación de sanciones y sus posibles repercusiones en su economía nacional ${ }^{124}$.

En el fondo, aquel anuncio respondía al desencuentro entre saudíes y emiratíes en relación con las estrategias y objetivos que cada una de las partes perseguían en el conflicto de Yemen. El principal objetivo saudí era debilitar a los hutíes para restaurar en el cargo al jefe de Estado reconocido internacionalmente, el presidente Abed Rabbo Mansour Hadi; expandir igualmente la influencia de Riad y mejorar su seguridad a lo largo de la frontera entre Arabia Saudita y Yemen $^{125}$. Los emiratíes, por su parte, han buscado ganar influencia en las zonas costeras de Yemen y en el sur del país, para asi fortalecer su presencia en las rutas marítimas del Golfo de Adén y el Estrecho de Mandeb, hacia el Cuerno de África. La falta de objetivos comunes ha llevado a ambos países a reforzar su presencia en provincias o gobernaciones políticamente divididas que no están bajo el control de los hutíes. Los emiratíes apoyan uno de los principales movimientos separatistas del sur, el Consejo de Transición del Sur (STC), que respalda sus demandas de independencia del sur de Yemen. El asesinato del ex presidente yemení 'Ali' Abdullah Saleh por los hutíes en diciembre de 2017, no ha frenado las aspiraciones emiratíes, sino que - al contrario - los Emiratos Árabes Unidos siguen ayudando a su sobrino Tareq Saleh a establecer unidades militares en la costa occidental de Yemen. El STC y las fuerzas de Tariq están oficialmente luchando contra los hutíes, pero se niegan a reconocer la legitimidad de Hadi. Los Emiratos Árabes Unidos ya han entrenado a unos 90.000 soldados, también paga salarios y les proporciona una fuerza terrestre eficaz como medio de influencia militar y política ${ }^{126}$. A pesar de esta importante participación, los Emiratos Árabes Unidos esgrimieron que ya no tenía sentido involucrarse en peleas por áreas que considera marginales para sus intereses. Su pragmatismo ha evitado una posible colisión con Teherán, aun cuando grupos proiraníes atacaron cuatro petroleros cerca de Fujairah en mayo de 2019. La anunciada reducción de fuerzas emiratíes en Yemen supuso además una medida de autoprotección al menos de cara a la galería internacional con la escenificación de su ruptura con Arabia Saudí y la coalición del CCG, anticipándose quizás a una posible reclamación de responsabilidad internacional ante la grave crisis humanitaria en Yemen, por lo que hasta el Congreso de los Estados Unidos busca bloquear la venta de armas a las naciones del Golfo. Pero a todas luces, los EAU no se han retirado de Yemen, sino que ahora persiguen y luchan por sus propios intereses, al margen de

\footnotetext{
123 Ibid.

${ }^{124}$ Al-Bakiri, Nabeel: “The UAE's withdrawal from Yemen”, Middle East Monitor. 12 July 2019 en https://www.middleeastmonitor.com/20190712-the-uaes-withdrawal-from-yemen/

${ }^{125}$ Nagi, Ahmed: "Yenemi borders markets: from economic incubator to military frontline", 14 June 2021 en https://carnegie-mec.org/2021/06/14/yemeni-border-markets-from-economic-incubator-to-military-frontlinepub-84752

${ }^{126}$ Nagi, Ahmed: “When Less May Mean More”, 22 July 2019, en https://carnegie-mec.org/diwan/79538
} 
la coalición que sigue liderada por Arabia Saudí ${ }^{127}$. Todos estos movimientos en la zona, no ha hecho más que generar más dudas acerca del próximo objetivo de Abu Dhabi ${ }^{128}$.

A pesar de estas diferencias. Arabia Saudí y Emiratos Árabes Unidos mantienen posiciones similares con respecto Irán su política regional y su programa nuclear, así como sobre la incertidumbre del compromiso estadounidense con la región. Ambos están reorganizando sus relaciones exteriores abriéndose a acuerdos con terceros países que mantienen posiciones de clara rivalidad con Estados Unidos.

\subsection{EI sorprendente intento de buenas relaciones de vecindad con Israel}

Las relaciones Arabia Saudí e Israel han sido prácticamente inexistes, al menos, hasta fechas recientes. La defensa del nacionalismo árabe de la Casa Saud se tradujo en una estrategia de política exterior armoniosamente orquestada. En 1967, los mandatarios árabes suscribieron tres principios esenciales: el no reconocimiento del Estado de Israel, ninguna negociación con ellos de ningún tipo y un claro no a la paz. El rey Faisal apoyó a los palestinos y la OLP, aunque su justificación no se debía exclusivamente al nacionalismo puro árabe, sino más bien al factor religioso, dada la importancia de Jerusalén como lugar sagrado islámico. Los saudíes consiguieron además que otros Estados musulmanes apoyasen la campaña contra Israel, y además financiaron a la OLP y a sus campos de entrenamiento en varios países árabes.

El revisionismo adoptado por Irán en los últimos tiempos está propiciando una honda preocupación en todos los Estados de la región. Esta incertidumbre ha favorecido nuevas alianzas impensables en épocas anteriores - como los Acuerdo de Abraham entre Israel, Emiratos Árabes Unidos y Bahréin - o al menos el acercamiento de Estados "enemigos" - como Israel y Arabia Saudí - cuyos planteamientos históricos-religiosos parecían aparentemente irreconciliables. En este nuevo contexto tiene plenamente actualidad ese proverbio árabe, que señala que "el enemigo de mi enemigo es mi amigo", por lo que Arabia Saudí e Israel deberían poder trabajar juntos para obtener una victoria conjunta contra Irán, en este caso. Irán se ha ganado las enemistades de Arabia Saudí, Israel o Bahréin al haber apoyado grupos insurgentes como los hutíes, el Ejercito al-Mahdi o Hamas ${ }^{129}$. Desde esta perspectiva, se podría contemplar que tanto Arabia Saudí como Israel, dejen de lado ciertos temas e intenten llegar a acercar posturas en otros para hacer un frente común contra Irán. Al menos esa es la idea del Príncipe Heredero saudí, quien en su plan de modernización y defensa de su Reino - la Visión 2030 está adoptado medidas drásticas también de carácter internacional para intentar alcanzar (o recuperar) el reconocimiento de la comunidad internacional y que Arabia Saudí sea un referente necesario en la región y en el mundo musulmán. Así pues, y a pesar de su discurso nacionalista árabe tradicional, se abre a alianzas incluso con Israel, para reforzar la nueva legitimidad oficial de la casa Al Saud y la lealtad al heredero ${ }^{130}$.

No será Arabia Saudí el primer Estado árabe en normalizar sus relaciones con Israel. Otros ya lo han hecho, alentados por la administración Tump como son los Emiratos Árabes Unidos, Bahréin, Sudán y Marruecos. Al parecer, en noviembre de 2020, Netanyahu, el Príncipe heredero Mohamed bin Salmán y el entonces secretario de Estado de los Estados Unidos, Mike

\footnotetext{
127 "UAE: Arab coalition is preparing for 'next phase in Yemen”, Middle East Monitor, 22 July 2019 en https://www.middleeastmonitor.com/20190722-uae-arab-coalition-is-preparing-for-next-phase-in-yemen/

${ }^{128}$ Kilani, Abdulaziz: “After Yemen, the UAE's next target could be Libya”, Middle East Monitor, 19 July 2019 , en https://www.middleeastmonitor.com/20190719-after-yemen-the-uaes-next-target-could-be-libya/

${ }^{129}$ Rahman, Omar H.: "The emergence of GCC-Israel relations in a changing Middle East”, 28 July 2021, en https://www.brookings.edu/research/the-emergence-of-gcc-israel-relations-in-a-changing-middle-east/

${ }^{130}$ Miller, David A., and Sokolsky, Richard: "Saudi Arabia and Israel Are Pushing US to Confront Iran. Trump Shouldn't Take the Bait”, 21 May 2019 en https://carnegieendowment.org/2019/05/21/saudi-arabia-and-israelare-pushing-us-to-confront-iran.-trump-shouldn-t-take-bait-pub-79181
} 
Pompeo se reunieron en secreto aprovechando la gira por Oriente Próximo de este último ${ }^{131}$. Aunque fue secreto y sin ningún tipo de publicidad ni confirmación oficial posterior, una simple reunión semi-informal ya es un avance hacia algún tipo de relación. Ya es un gesto también que las autoridades saudíes permitan que los vuelos comerciales israelíes sobrevuelen el espacio aéreo saudí en transito hacia Emiratos y Bahréin, a pesar del boicot de los vuelos que mantienen los países de la Liga Árabe. Tan solo se sabe por el tuit del secretario de Estado norteamericano que la visita a Mohamed bin Salmán fue fructífera y que posteriormente viajaba a reunirse con el grupo de países del Golfo que ya han normalizado sus relaciones diplomáticas con el Estado judío y que hacen frente común en su política de "máxima presión" sobre Irán.

La casa Al Saud todavía no ha avanzado nada concreto en esa dirección, porque existen fuertes discrepancias al respecto en la familia real. Por una parte, el Príncipe heredero es partidario de establecer vínculos formales con Israel, pero su padre, el rey Salmán parece querer actuar con máxima cautela, pensando en ciertos sectores más conservadores y religiosos de su reino. En cambio, el príncipe Turki al Faisal sí que se atrevió a criticar duramente al Estado judío por su trato a los palestinos y lo acusó de hipocresía por su arsenal nuclear. Para calmar a los ánimos, el ministro de Exteriores saudí, Bin Farhan, subrayó que sería muy deseable que el Reino estableciese lazos con Israel, pero que no mantendría relaciones diplomáticas mientras no exista un amplio acuerdo de paz entre israelíes y palestinos, según la iniciativa árabe de paz que apadrinó Arabia en 2002.

La normalización de las relaciones entre Arabia Saudita e Israel ayudaría a cada una de las partes a lograr una serie de objetivos estratégicos y militares. Los futuros resultados no serán necesariamente tan transformadores como proclama los partidarios de estas nuevas alianzas, aunque es posible que las transformaciones no funcionen como cabria razonablemente esperar. La analista Yasmine Farouk analiza las metas previstas por los defensores de la normalización de las relaciones Arabia Saudí-Israel, aunque las probabilidades de que se alcancen parecen lejanas en el tiempo ${ }^{132}$. La citada experta llega a la conclusión de que la normalización de las relaciones entre ambos países difícilmente podrá promover la paz o la estabilidad en Oriente Medio; es más, a su juicio, dicha normalización no siempre podrá promover los intereses de los Estados Unidos en la región. Tampoco garantiza la modernización de Arabia Saudí, ni podrá abarcar todos los asuntos que separan a Riad de Washington. Cabe esperar que el liderazgo saudí busque algo más que el tradicional "alto precio" - la creación de un estado palestino soberano a cambio de la normalización de las relaciones - tal y como ya se están discutiendo en varios foros pro palestinos en Riad. En su caso, la normalización de las relaciones entre Arabia Saudí e Israel no significará necesariamente que las dos naciones se hagan amigas, a pesar de que ya existen ecos favorables para el gobierno saudita que postulan que Israel no amenazará a los países del Golfo. Por el contrario, los palestinos en ocasiones han sido acusados de chantajear a Arabia Saudita y evitar que ponga sus intereses nacionales en primera fila. Esta narrativa afecta directamente a la identidad nacional saudí que la antepone por encima de la identidad árabe o incluso islámica. En suma, a pesar de la teórica voluntad de Arabia Saudí e Israel de normalizar sus relaciones, en la situación actual se dan todos los ingredientes para que la paz no sea cálida ni realista en el corto plazo.

Hay que tener presente, no obstante, que este posible acercamiento de posturas entre Arabia Saudí e Israel no se está cuajando en un momento cualquiera, ni parece responder a una

\footnotetext{
${ }^{131}$ Miller, David A. and Sokolsky, Richard:" How Biden Will End the Trump Sugar High for Israel and Saudi Arabia", 22 February 2021, en https://www.politico.com/news/magazine/2021/02/22/how-biden-will-end-thetrump-sugar-high-for-israel-and-saudi-arabia-470911

${ }^{132}$ Farouk, Yasmine: "What Would Happen If Israel and Saudi Arabia Established Official Relations?”, 15 October 2020, en https://carnegieendowment.org/2020/10/15/what-would-happen-if-israel-and-saudi-arabiaestablished-official-relations-pub-82964
} 
iniciativa exclusiva de judíos y saudíes; al contrario, parece guiada y teledirigida por los Estados Unidos, cuyos intereses parecen alinearse como resultado de la incorporación de la región a la económica mundial, en especial, gracias los beneficios del petróleo, así como a la digitalización y una cierta occidentalización de las nuevas generaciones de saudíes. Además, la normalización de las relaciones con Israel ayudaría a Arabia Saudí lograr varios de sus objetivos estratégicos del Saudi Vision 2030. Puesto que busca sanear y diversificar la economía reduciendo su dependencia del petróleo Israel podría aportarle su experiencia en ciberseguridad, inteligencia artificial y emprendimiento e impulsaría proyectos de cooperación en agricultura y turismo, de esta forma Arabia Saudí podría acceder a nuevos mercados y fuentes de inversión ${ }^{133}$. Pero todavía es prematuro discutir estas cuestiones de fondo, ya que antes debe hacerse un estudio "coste-beneficio" para cerciorarse después la voluntad política de todas las partes implicadas. Seguramente Biden será clave en estas negociaciones, puesto que ya se ha alejado de la postura agresiva de su predecesor y utiliza diplomáticamente a su favor las negociones entre Riad y Tel Aviv como moderna de cambio en su política con Irán y viceversa.

\section{Conclusión}

Muchas son las cuestiones que se suscitan en estas páginas y todas ellas me llevan a varias reflexiones finales, que difícilmente se pueden plasmar de forma breve, clara y concisa. En el fondo de todas ellas late un interrogante final: ¿puede y quiere un Estado, como el Reino de Arabia Saudí acometer reformas sistémicas de política nacional e internacional adaptadas a las exigencias democráticas y de derechos humanos del siglo XXI sin perder la esencia de su tradición, cultura e identidad?

La perdurabilidad de la Corona Saud se halla en la capacidad de poder equilibrar fuerzas centrífugas tan diversas como la soberanía, la fe, la economía y los derechos humanos en un sistema autoritario para ir combinando la inserción progresiva de medidas reformadoras con la protección de los valores wahabís, que constituyen su identidad nacional. Esto es lo que algunos denominan "el dilema del rey" 134 , que implica que la transformación progresiva en la naturaleza autoritaria de un régimen puede conllevar nuevos problemas, una mayor fragmentación de la sociedad y la erosión del poder.

El reinado de Salman comenzó enfrentándose a una serie de desafíos sin precedentes y novedosos, muy significativos, que exigían cambios de dirección por la caída de los precios del petróleo y las nuevas exigencias regionales e internacionales. Su reinado sigue suscitando dudas y recelos, pero no hay duda, de que se está configurando un nuevo reino ${ }^{135}$. Así las cosas, el dilema del Príncipe Heredero de la dinastía Saud consiste en avanzar hacia su Visión 2030 con paso firme entre los suyos y mantenido el poder a través de un doble pacto fáustico: con Occidente, que ya le ha proporcionado seguridad a lo largo de los años a cambio de petróleo; y con los clérigos wahabíes, que le siguen ofreciendo legitimidad religiosa a cambio del poder del Estado para difundir su versión intolerante del islam.

Sin duda, es bueno tener a los Al Saud, como amigo más que como enemigo ante el atractivo del petróleo, los recursos naturales y control de los lugares sagrados musulmanes, ya que el repudio del yihadismo lo hacen mejor los musulmanes piadosos que los drones armados o las sanciones. Sin embargo, el wahabismo que fundamenta el poder del Estado saudí puede llegar a poner en peligro a la dinastía misma y al inestable equilibrio regional, si mantiene una

\footnotetext{
${ }^{133}$ Arechalde, Begoña: Por qué Israel y Arabia Saudí (todavía) no van a normalizar relaciones, 28 de febrero de 2021, en https://elordenmundial.com/por-que-israel-y-arabia-saudi-no-van-todavia-a-normalizar-relaciones/

${ }^{134}$ Aarts, Paul y Roelants, Carolien (2015): Saudi Arabia, a kingdom in peril., London, Hurst \& Company, pp. 143-144.

${ }^{135}$ Al-Rasheed, Madawi: Salman's Legacy. The Dilemmas of a New Era in Saudi Arabia, op.cit., p. 18.
} 
ideología yihadista, que avive el sectarismo y exponga a la monarquía a acusaciones de hipocresía o de traición, si se rinde ante el nuevo oro de las tecnologías occidentales o israelíes.

Las primaveras árabes vividas en Libia Siria, Irak y Yemen, han demostrado que las monarquías del Golfo son más resistentes. Con cautela y de forma suave y progresiva se han ido reformando ciertas estructuras. Sin embargo, en la actualidad han cambiado las tornas y ante el atractivo Fondo soberano saudí, va a ser más que probable que más de un Gobierno aguante el reproche saudí - que encierra una gran verdad - que ciertos Estados vuelvan solo a interesarse por Arabia Saudí cuando hay mucho dinero en juego y lo ignoren en otros conflictos de Oriento Medio y otras cuestiones de la agenda internacional que sean importantes para la casa Saud. Pese a todo, se puede afirmar que ya se avanza hacia un nuevo horizonte en Arabia Saudí impulsado por el príncipe heredero Mohamed bin Salmán, En su lugar, un Estado más moderno, pero igualmente autoritario sunní, diseña y ejecuta una diversificación geopolítica y económica, asumiendo el turismo de lujo y el deporte como "moneda de cambio" o "lavado de imagen" de un Reino que con sus contradicciones y debilidades internas es - sin duda - un coloso en la Península Arábiga y en el Golfo Pérsico y que sigue extendiendo sus alianzas y enemistades, por extrañas que parezcan y a pesar de los pesares nacionales e internacionales.

La proyección de poder de los Estados Unidos en la región ha aumentado y disminuido, casi en igual medida, incluso cuando su enemistad hacia Irán ha perdurado. Arabia Saudita y los demás actores del Golfo han aprendido a no confiar plenamente en su poderoso patrocinador, pues las sucesivas administraciones en Washington han continuado extendiendo un paraguas estratégico protector sobre estos aliados, aunque no siempre lo han hecho con gran ecuanimidad o entusiasmo, evitando comprometerse con garantías de seguridad o reseguros ${ }^{136}$. Recuérdese cómo en enero de 2021, el presidente Joe Biden dio la orden de suspender las ventas de armas a Arabia Saudí y a Emiratos Árabes Unidos, para forzar el fin del conflicto yemení, una decisión aplaudida y criticada, casi por partes iguales.

Ante esta evolución, se puede entender mejor cómo los planteamientos futuristas del Príncipe heredero saudí no conocen de límites geopolíticos, y cómo el actual acercamiento entre Riad y Moscú resulta muy ventajoso para ambos países, por distintos motivos, pero parcialmente coincidentes. Ambos Estados tienen una economía muy dependiente de los hidrocarburos; ambos están interesados en impedir que bajen los precios del crudo y ambos pueden beneficiarse de proyectos de colaboración en sectores que van desde la petroquímica hasta la agricultura y que, sin duda, pasan también por el sector armamentístico. Los dirigentes rusos ven las potenciales inversiones saudíes como una forma de superar las sanciones financieras a las que se ven sometidos por Occidente a causa de su intervención en Ucrania en 2014. Mientras que los saudíes ganan aliados fuera del Golfo, al mismo tiempo que ganan poder disuasorio en el CCG. Este beneficio mutuo pone en jaque a la ya de por sí compleja relación entre Washington y Riad y, en cambio, la entente Riad-Moscú puede transformarse en una cierta hegemonía e influencia rusa trascendente en la zona, aprovechando la convulsa situación de ciertos países, como es el caso de Afganistán o las decisiones estratégicas de otros, como Irán, quien desde septiembre de 2021 es miembro de pleno derecho de la Organización de Cooperación de Shanghai. Sean cual sean los objetivos iraníes en esta Organización, su libertad de maniobra dentro del bloque seguirá estando algo limitada por las amenazas planteadas por las sanciones secundarias de Estados Unidos, así como por el régimen internacional de prevención del blanqueo de capitales, incluso si cierta proporción de las transacciones con los vecinos de Irán se puede ocultar con éxito. Más importante aún, Moscú y Beijing son las dos

\footnotetext{
${ }^{136}$ Hiltermann, Joost. "From Diatribes to Dialogue: Why Iran and Saudi Arabia Are Talking”, 7 May 2021, en https://www.crisisgroup.org/middle-east-north-africa/gulf-and-arabian-peninsula/iran/diatribes-dialogue-whyiran-and-saudi-arabia-are-talking
} 
partes interesadas más poderosas dentro de la OCS, y están persiguiendo sus propios intereses geopolíticos a través de la Organización, enfocados más en las amenazas a la seguridad que en los acuerdos económicos dentro del foro. Pero no hay que ignorar que Rusia y China están buscando nuevas formas de cooperación y no solo relaciones bilaterales con Irán, a pesar de que todavía está presente el acuerdo sobre su programa nuclear, sino que además buscan, sin duda, beneficiarse de la posición regional de Irán en la península arábiga y sus Estados vecinos. China también se beneficiará del repliegue estadounidense, incrementando su cooperación militar y económica. En consecuencia, el tiempo dirá si las nuevas amistades políticas en el Golfo pueden afianzarse y si consiguen rellenar los vacíos que cree la nueva política exterior los Estados Unidos y, en menor medida, de la Unión Europea, que gradualmente va quedando relegada ante la creciente influencia asiática ${ }^{137}$.

\section{Bibliografía}

"Arabia Saudí y Rusia sellan veinte acuerdos durante la visita de Putin”, La Vangardia, 14 de octubre de 2019.

"Saudi Arabia Backgrounder: Who are the Islamists?", International Crisis Group, Middle East and North Africa, 21 September 2004, en https://www.crisisgroup.org/middle-east-northafrica/gulf-and-arabian-peninsula/saudi-arabia/saudi-arabia-backgrounder-who-are-islamists.

Aarts, Paul. y Roelants, Carolien. (2015): Saudi Arabia, a kingdom in peril. Hurst \& Company, Londres.

AL Qassemi, Sultan: "Qatar's Brotherhood Ties Alienate Fellow Gulf States" en Al Monitor, 23 January 2013.

Al Yousif, Mohammed y Al Bakr, Ahmed: “Tourism Development Effect on Saudi Economic Diversification", SAMA Working Paper, March 2017, en

https://islamicmarkets.com/publications/tourism-development-effect-on-saudi-economicdiversification

Al-Bakiri, Nabeel: “The UAE's withdrawal from Yemen". Middle East Monitor, 12 July 2019 en https://www.middleeastmonitor.com/20190712-the-uaes-withdrawal-from-yemen/

Al-Ghamdi, Saleh bin Mohammed: "Saudi Foreign Policy-The policy of principles", en The Saudi non-resident Ambassador to Bulgaria delivers a lecture at the Diplomatic Institute of Sofia. Diplomatic Institute of the Ministry of Foreign Affairs of Bulgaria, 30 March 2011, en https://www.mofa.gov.sa/sites/mofaen/KingdomForeignPolicy/Pages/ForeignPolicy24605.aspx

Al-Rasheed, Madawi (2018): Salman's Legacy. The Dilemmas of a New Era in Saudi Arabia, Oxford University Press

Al-Rasheed, Madawi (2003): Historia de Arabia Saudí, Cambridge, Cambridge University Press

\footnotetext{
${ }^{137}$ Braunstein, Jürgen and McPherson-Smith, Oliver: "Although cooperation with China can help Saudi Arabia boost production of solar power, global trade dynamics may complicate the kingdom's renewable energy goals", 7 May 2019 en https://carnegieendowment.org/sada/79079
} 
Al-Rasheed, Madawi (2013): A most masculine state. Gender, politics and religion in Saudi Arabia. New York, Cambridge University Press.

Al-Rasheed, Madawi (2021): The Son King Reform and Repression in Saudi Arabia, Oxford, Oxford University Press.

Alahmed, Ali: "Which lesson will Biden teach MBS?", 5 May 2021, en https://thehill.com/opinion/international/554814-which-lesson-will-biden-teach-mbs

Alghussein, Bassima and Stacey, Jeffrey. "How Saudi Arabia Botched Its Campaign Against Qatar. The Costs of the Pressure on Doha" Foreign Affairs, 12 July 2017 en https://www.foreignaffairs.com/articles/middle-east/2017-07-12/how-saudi-arabia-botchedits-campaign-against-qatar

"An unholy pact", The Economist, 25 January 2015, en https://www.economist.com/leaders/2015/01/29/an-unholy-pact

Arechalde, Begoña: "Por qué Israel y Arabia Saudí (todavía) no van a normalizar relaciones", 28 de febrero de 2021, en https://elordenmundial.com/por-que-israel-y-arabia-saudi-no-vantodavia-a-normalizar-relaciones/

Baker, Aryn: "Down and out in Saudi Arabia" Time, 3 June 2013, en http://content.time.com/time/subscriber/article/0,33009,2144028-1,00.html

Baskan, Birol y Wright, Steven: "Seeds of change: comparing state-religion relations in Qatar and Saudi Arabia" Arab Studies Quarterly. vol.33, nº 2 (Spring 2011), pp. 96-111.

Bermejo García, Romualdo y Gutiérrez Espada, Cesáreo: "El programa nuclear iraní en el ojo del huracán”, Revista Española de Derecho Internacional, vol. 57, n. 1 (2005), pp. 105-119.

Bermejo García, Romualdo y López-Jacoiste Diaz, Eugenia: "La reforma institucional de Naciones Unidas", UNISCI Discussion Papers, $\mathrm{n}^{\circ} 10$ (January/enero 2006), en http://www.unisci.es/la-reforma-institucional-de-las-naciones-unidas/

Bermúdez, Ángel: “Arabia Saudí vs Irán: por qué estos archirrivales han iniciado un diálogo "sin precedentes"” BBC News Mundo, de 19 de mayo de 2021, en https://www.bbc.com/mundo/noticias-internacional-57124106.

Biosca Aizcoiti, Javier: "La princesa y el príncipe desaparecidos de Arabia Saudí: los suyos confían en el poder de Biden para su salvación", El Diario.es, 6 de febrero de 2021, en https://www.eldiario.es/internacional/principes-desaparecidos-arabia-saudi-confianbiden-liberacion_1_7191024.html

Bordón, Javier: "El conflicto de Yemen y Arabia Saudí: sin influencia para resolver, pero con motivos para no hacerlo", Real Instituto Elcano, 23 de julio de 2020, ARI, 70/2021,

Braunsteine Jürgen and McPherson-Smith, Oliver: "Although cooperation with China can help Saudi Arabia boost production of solar power, global trade dynamics may complicate the kingdom's renewable energy goals", 7 May 2019, en https://carnegieendowment.org/sada/79079

Braunsteine Jürgen and McPherson-Smith, Oliver "Although cooperation with China can help Saudi Arabia boost production of solar power, global trade dynamics may complicate the kingdom's renewable energy goals", 7 May 2019, en https://carnegieendowment.org/sada/79079

Carter Ash (2019): Inside the Five-Sided Box, New York, Penguin. 
Clinton Hillary Rodhan (2014): Hard Choises, New York, Simon \&Shuster

Conceição, Pedro: La Próxima frontera. El desarrollo y el Antropoceno, Informe sobre desarrollo humano 2020, en

http://hdr.undp.org/sites/default/files/hdr_2020_overview_spanish.pdf

Cuadro, Mariela: "Nuevo rey y cambios en la política saudí: de la amenaza de la Hermandad Musulmana al peligro iraní", Anuario de Relaciones Internacionales, Departamento de Oriente Medio, 2015, en

https://www.iri.edu.ar/publicaciones_iri/anuario/anuario_2015/Demo/AS\%20por\%20MC.pd

Dazi-Héni, Fatiha: “Arabia Saudí contra Irán: un equilibrio regional de poder", Revista de análisis y pensamiento sobre el mundo árabe e islámico contemporánea, n. ${ }^{\circ} 8$ (2013), pp. 2335 .

Domínguez Diaz, Francisco Antonio. (2020): "Monográfico sor el mundo árabe”, en Estudios contemporáneos sobre geopolítica, conflictos armados y cooperación internacional, Libia Arenal Lora (coord.), Universidad Internacional de Andalucía.

Dorsey, James M. (2017): "Saudi crackdown raises specter of wider dissent", The Begin-Sadat Center for Strategic Studies, BESA Center Perspectives Paper $n^{\circ}$ 635, 6 November 2017, en https: https://besacenter.org/saudi-crackdown/

Dorsey, James M.: The Russian FM's Gulf Tour. A Bellwether of US Saudi Relations, The Begin-Sadat Center for Strategic Studies, BESA Center Perspectives Paper no 1956, 9 March 2021.

Echeverría, Carlos: "La dimensión ideológica del Islam y del Islamismo y su reflejo a lo largo de la historia", en Carlos Echeverría (coord.) (2018): Democracia e Islam, ¿una relación imposible? Comares, Granada, pp. 1-12.

El-Erian, Mohamed A: "Saudi Arabia's attempt to reduce reliance on oil has the world rapt", The Guardian, 16 May 2016, en

https://www.theguardian.com/business/2016/may/16/saudi-arabia-reduce-reliance-oil-vision2030

Europa Press, "Los países del Golfo firman un acuerdo para poner fin a la crisis diplomática con Qatar", 5 de enero de 2021, en

https://www.europapress.es/internacional/noticia-principe-heredero-saudi-recibe-emir-qatarcumbre-ccg-acuerdo-reabrir-fronteras-20210105130309.html

Evans, Malcolm: "Case concerning maritime delimitation and territorial questions between Qatar and Bahrein (Qatar v. Bahrein)", The International and comparative Law Quarterly, vol. 51 (2002), pp. 709-772

Even, Shamuel y Guzansky, Yoel: "Saudi Arabia's Vision 2030: Reducing the Dependency on Oil", The Institute for National Security Studies, INSS Insight. ${ }^{\circ}$ 819, 6 May 2016, en http://www.inss.org.il/publication/saudi-arabias-vision-2030-reducingthe-dependency-on-oil/

Farouk, Yasmine: "Saudi Arabia's Foreign Policy", 24 May 2021, en https:/gjia.georgetown.edu/2021/05/24/dr-yasmine-farouk-on-saudi-arabias-foreign-policy/

Farouk, Yasmine: "What Would Happen If Israel and Saudi Arabia Established Official Relations?", 15 October 2020, en https://carnegieendowment.org/2020/10/15/what-wouldhappen-if-israel-and-saudi-arabia-established-official-relations-pub-82964 
Fathallah, Hadi: "The implementation of Vision 2030 is bypassing state institutions, creating a public policy crisis and further weakening government institution”, 22 May 2019, en https://carnegieendowment.org/sada/79188

Gardner, Frank: "Saudi Arabia's king Salman marks year of change" BBC News, 22 de enero de 2016, en https:// www.bbc.com/news/world-middle-east-35370801

Ghattas, Kim: "What Jamal Khashoggi's Murder Tells Us About the Saudi-Iran Rivalry", 2 October 2019, en https://carnegieendowment.org/2019/10/02/what-jamal-khashoggi-s-murdertells-us-about-saudi-iran-rivalry-pub-79988

Gil Pérez, Javier (2018): “Análisis de las políticas exteriores de los grandes faros iluminadores del islamismo en la actualidad: Arabia Saudí, Qatar, Turquía, Emiratos Árabes Unidos, Kuwait e Irán”, en Carlos Echeverría (coord.): Democracia e Islam, ¿una relación imposible? Comares, Granada.

Hadifi, Meryen. "La nueva geopolítica rusa en Oriente Medio", Atalayar, 24 agosto 2021, en https://atalayar.com/content/la-nueva-geopol\%C3\%ADtica-rusa-en-oriente-medio

Hakala, Pekka. (2013): "Cautions reform in Saudi Arabia”, Directorate General for Internal Policies, European Parliament, en

https://www.europarl.europa.eu/RegData/etudes/briefing_note/join/2013/491504/EXPO-

AFET_SP(2013)491504_EN.pdf

Hammond, Andrew: "Liberal pockets in Saudi Arabia's rigid state", Reuters, 19 August 2008, en https://www.reuters.com/article/us-saudi-econcities-society-idUSL22101098020080820

Harvey, Katherine (2021): A Self-Fulfilling Prophecy. The Saudi Struggle for Iraq, C Hurst \& Co Publishers Ltd.

Herdenson, Simon: "Saudi visit to Washington will have a thorny agenda", 6 July 2021, en https://www.washingtoninstitute.org/policy-analysis/saudi-visit-washington-will-have-thornyagenda

Herdenson, Simon: "Saudi visit to Washington will have a thorny agenda", 6 July 2021, en https://www.washingtoninstitute.org/policy-analysis/saudi-visit-washington-will-have-thornyagenda

Hernández Martínez, David. "La Alianza de Estados Unidos y Arabia Saudí en el siglo XXI. La presidencia de Georg W. Bush, Barack Obama y Donald Trump", Revista del Instituto Español de Estudios Estratégicos, nº 15 (2020), pp. 43-66.

Hernández Martínez, David. (2020): El reino de Arabia Saudí, Madrid, Catarata,

Hiltermann.Joost: "From Diatribes to Dialogue: Why Iran and Saudi Arabia Are Talking", International Crisis Group, 7 May 2021, en https://www.crisisgroup.org/middle-east-northafrica/gulf-and-arabian-peninsula/iran/diatribes-dialogue-why-iran-and-saudi-arabia-aretalking

Hussain, Zakir. "Saudi Arabia‘s Red Sea Project: Harnessing Tourism for Diversifications", Indian Council of World Affairs, (August 2017), pp. 1-11.

ICG Middle East: “Can Saudi Arabia Reform Itself?", Report no 28, 2014 en https://www.crisisgroup.org/middle-east-north-africa/gulf-and-arabian-peninsula/saudiarabia/can-saudi-arabia-reform-itself

Jahner, Ariel: "Saudi Arabia and Iran: The struggle for power and influence in the Gulf", International Affairs Review, vol. XX, nº 3 (Spring 2012), pp. 37-50 
James G. Blight et al. (2012): Becoming Enemies U. S.-Iran Relations and the Iran-Irak War, 1979-1988. Lanham (Maryland), Rowman \& Littlefield Publishers.

"Joe Biden looks to end the war in Yemen", The Economist, 11 February 2021, en https://www.economist.com/middle-east-and-africa/2021/02/13/joe-biden-looks-to-end-thewar-in-yemen

Johnson, Keith and Gramer, Robbie: "How the Bottom Fell out of the U.S.-Saudi Alliance", 23 April 2020, en https://foreignpolicy.com/2020/04/23/saudi-arabia-trump-congress-breakingpoint-relationship-oil-geopolitics/

Jones, Toby Craig: (2010): Desert Kingdom. How oil and water forged modern Saudi Arabia. Harvard University Press, London.

Joyner, Daniel H.: (2016): Iran's nuclear program and the international law: from confrontation to accord, New York, Oxford University Press.

Kerry, John (2018): Every Day is Extra, New York, Simon \& Shuster.

Khan, Taimur: "How Qatar's Policy on the Muslim Brotherhood Burns the GCC", Nacional, 19 de marzo de 2014, en

www.thenational.ae/world/qatar/20140319/how-qatars-policy-on-the-muslim-brotherhoodquema-el-gcc \# ixzz39bWOE3zf .

Kilani, Abdulaziz: “After Yemen, the UAE's next target could be Libya”, Middle East Monitor July 19, 2019, en https://www.middleeastmonitor.com/20190719-after-yemen-the-uaes-nexttarget-could-be-libya/

"La Supercopa se jugará en Arabia Saudí los próximos tres años a cambio de 40 millones por temporada", La Vanguardia, 11 de noviembre de 2019, en https://www.lavanguardia.com/deportes/futbol/20191111/471524510810/supercopa-

espanaarabiasaudi-tres-temporadas-40-millones.html

Legranzi, Matteo: “La Nuova Arabia Saudita: ¿isolata o protagonista?”, Vita e Pensiero, vol. 6, (2017), pp. 47-52.

Legranzi, Matteo: "Shaking things up: Gulf security after Iran deal", INSSSL Defence Review Colombo, Institute of National Security Studies Sri Lanka, vol. 1, (2017), pp. 41-48, https://www.lavanguardia.com/vida/20180508/443428775602/arabia-saudi-apoya-decisionde-trump-de-retirarse-del-pacto-nuclear-con-iran.html

Leyland, Adam: "Saudi Arabia could be bankrupt within five years, IMF predicts" The Independent, 24 October 2015 en

https://www.independentespanol.com/?utm_source=redirect

Lin, Christina: "ISIS and the Saudi Wahhabi Threat to Asian Security", ISPSW Strategy Series: Focus on Defense and International Security, no 365 (July 2015).

Lopes da Silva, Diego, and Marksteiner, Alexandra: "Trends in world military expenditure, 2020", SIPRI Fact Sheet. (April 2021), pp. 1-12, en https://sipri.org/sites/default/files/202104/fs_2104_milex_0.pdf

López-Jacoiste Diaz, Eugenia. "La crisis de Libia desde la perspectiva de la responsabilidad de proteger", Anuario Español de Derecho Internacional, XXVII, (2011), pp.109-152.

Lynch, Marc: “Saudi Arabia's Counter-Revolution” Foreign Policy. 10 August 2011.

Mabon, Simon: "Muting the Trumpets of Sabotage: Saudi Arabia, The US and quest o to Securitize Iran", British Journal of Middle Eastern Studies. vol. 45, nº 5 (2017), pp. 1-18. 
Mikaïl, Barah: "Geopolítica del conflicto entre sunníes y chiíes: una visión global”, Revista de análisis y pensamiento sobre el mundo árabe e islámico contemporánea, $\mathrm{n}^{\circ}$ 8, (2013), pp. 1-17.

Miller, David A: "The Future of U.S.-Saudi Relations Following Report Tying Khashoggi Killing Approval to Crown Prince, 1 March 2021, en https://archive.kpcc.org/programs/airtalk/2021/03/01/66544/the-future-of-us-saudi-relationsfollowing-report

Miller, David A. and Sokolsky, Richard: "How Biden Will End the Trump Sugar High for Israel and Saudi Arabia", 22 February 2021, en

https://www.politico.com/news/magazine/2021/02/22/how-biden-will-end-the-trump-sugarhigh-for-isra

Miller, David A., and Sokolsky, Richard: "Saudi Arabia and Israel Are Pushing US to Confront Iran. Trump Shouldn't Take the Bait", 21 May 2019 en https://carnegieendowment.org/2019/05/21/saudi-arabia-and-israel-are-pushing-us-toconfront-iran.-trump-shouldn-t-take-bait-pub-79181

Miller, David A., and Sokolsky, Richard: "Saudi Arabia is a partner, not an ally. Let's stop the charade", The Washington Post, 4 March 2021, en

https://www.washingtonpost.com/outlook/2021/03/04/biden-khashoggi-saudi-arabia-crownprince/

Monge, Yolanda: "EEUU hace efectiva la salida de Afganistán al abandonar la base militar de Bagram”, El País, 2 de julio de 2021, en https://elpais.com/internacional/2021-07-02/estadosunidos-se-retira-de-bagram-su-base-mas-importante-en-afganistan.html

Morán, Carlos: "El AVE a la Meca: las claves del nuevo conflicto de Arabia Saudî", Expansión, de 18 de febrero de 2020 en

https://www.expansion.com/empresas/transporte/2020/02/18/5e4afde9468aebad7c8b45c7.ht $\mathrm{ml}$

Nagi, Ahmed: "Yenemi borders markets: from economic incubator to military frontline", 14 June 2021, en https://carnegie-mec.org/2021/06/14/yemeni-border-markets-from-economicincubator-to-military-frontline-pub- 84752

Nagi, Ahmed: When Less May Mean More", 22 July 2019, en https://carnegiemec.org/diwan/79538

Navarro, Beatriz: "La CIA acusa al príncipe heredero saudí de "ordenar" el asesinato de Khashoggi", La Vanguardia, 27 de febrero de 2021, en https://www.lavanguardia.com/internacional/20210226/6260394/cia-arabia-saudi-principekhashoggi-disidente.html

"Neom: la ciudad futurista del Príncipe heredero saudí", (diciembre de 2017) https://www.gualestrit.com/neom-la-ciudad-futurista-del-principe-heredero-saudi

Obama Barack (2020): Una tierra prometida, Barcelona, Debate, 928 pp.

Ottaway, Marina y Muasher, Marwan: “Arab monarchies. Chance for reform, yet unmet" Carnegie Endowment for International Peace.The Carnegie paper. Middle East, December 2011 en http://carnegieendowment.org/2011/12/16/arabmonarchies-chance-for-reform-yet-unmetpub-46243

Parsi, Trita: "Why Mohammed bin Salman wants to talk to Iran", Foreign Policy, 29 April 2021 en https://foreignpolicy.com/2021/04/29/saudi-arabia-iran-uae-mohammed-bin-salman-secret-talksbiden-withdrawal-pivot-middle-east/ 
Poza Cano, David: “El derrumbe del 'statu quo' en Oriente Próximo: las estrategias de seguridad de Irán y Arabia Saudî”, Instituto Español de Estudios Estratégicos, Documento de Opinión, n. ${ }^{\circ} 10$ (2017), pp. 1-16, en

http://www.ieee.es/Galerias/fichero/docs_opinion/2017/DIEEEO10-

2017_OrienteProximo_DavidPoza.pdf

Pozo Serrano, Pilar: "La retirada de Estados Unidos del Plan de Acción Integral Conjunto y la reimposición de sanciones a Irán: aspectos jurídicos y políticos”, Anuario Español de Derecho Internacional, vol. 35 (2019), pp. 219-259.

Priego Moreno, Alberto: "La Primaveras Árabes: la influencia de Catar y sus relaciones con los Estado del Golfo", Revista UNISCI, n. 39 (octubre 2015), pp. 233-253, p. 234

Priego Moreno, Alberto: "La nueva política exterior de Arabia Saudî”, Instituto Español de Estudios Estratégicos, Documento marco, n. ${ }^{\circ} 18$ (2015), pp. 1-20, en http://www.ieee.es/Galerias/fichero/docs_marco/2015/DIEEEM18-

2015_NuevaPoliticaExterior_ArabiaSaudi_A.Priego.pdf

Rahman, Omar H.: "The emergence of GCC-Israel relations in a changing Middle East", 28 July 2021, en https://www.brookings.edu/research/the-emergence-of-gcc-israel-relations-in-achanging-middle-east/

Rodríguez, Ana: “Arabia saudí invierte más de 7.700 millones de dólares en algunas de las empresas más conocida del mundo", Atalaya, 18 de mayo de 2020.

Sáinz Jorge: "Pedro Sánchez busca inversiones el fondo soberano saudí para rescatar empresas españolas", Voz populi, 21 de febrero de 2021, en https://www.vozpopuli.com/espana/sanchezarabia-saudi-rescatar-empresas.html

Seilkay, May, Roodsaz, Rahil y Van Egten, Corine: "The situation of the women in the Gulf States", Directorate General for Internal Policies, European Parliament, 2014 en https://www.europarl.europa.eu/RegData/etudes/STUD/2014/509985/IPOL_STU(2014)5099 85_EN.pdf

Shane, Scott: "Saudis and Extremism 'Both the Arsonists and the Firefighters", New York Times, 26 August 2016.

SIPRI Yearbook 2020: Armaments, disarmament and international security, Oxford, Oxford University Press, 2020.

Smith, Saphora and De Luce, Dan: "U.S.-Saudi ties were especially close under Trump. Biden, the looks likely to change", 12 November 2020, en https://www.nbcnews.com/news/world/lessprivileged-personal-how-u-s-saudi-ties-may-soon-n1247439

Taher, Abdulhadi Hassan (2011): Petroleum, gas and development strategies of Saudi Arabia. London, Saqi Books.

Teitelbaum, Joshua: "Saudi Arabia and the new strategic landscape," Middle East Review of International Affairs, vol. 14, $\mathrm{n}^{\mathrm{o}} 3$ (September 2010) pp. 38-44.

Wilson, Peter W. y Graham, Douglas F. (1994): Saudi Arabia. The coming storm. M.E. Sharpe, Nueva York, pp. 131-133.

Yamani, Mai: “The two faces of Saudi Arabia”, Survival. vol. 50, n 1 (February-March, 2008), pp. 143-156.

Yom, Sean L. y Gause, Gregory: "Resilient royals: how Arab monarchies hang on”, Journal of Democracy, vol. 23, nº 4 (October 2012), pp. 74-88. 